UNIVERSIDADE DE SÃO PAULO

FACULDADE DE FILOSOFIA, LETRAS E CIÊNCIAS HUMANAS

DEPARTAMENTO DE GEOGRAFIA

PROGRAMA DE PÓS-GRADUAÇÃO EM GEOGRAFIA HUMANA

\title{
O ESPAÇO VERTIGINOSO
}

Alexander Sergio Evaso

Dissertação apresentada ao Programa de PósGraduação em Geografia Humana, do Departamento de Geografia da Faculdade de Filosofia, Letras e Ciências Humanas da Universidade de São Paulo.

Orientador: Profa. Dra. Maria Laura Silveira 


\section{UNIVERSIDADE DE SÃO PAULO \\ FACULDADE DE FILOSOFIA, LETRAS E CIÊNCIAS HUMANAS \\ DEPARTAMENTO DE GEOGRAFIA \\ PROGRAMA DE GEOGRAFIA HUMANA}

\section{O ESPAÇO VERTIGINOSO}

Alexander Sergio Evaso

São Paulo

2006 


\section{SUMÁRIO}

Índice

Índice das Tabelas

Índice das Figuras

Resumo

Abstract

Introdução

Capítulo I

Capítulo II

Capítulo III

Conclusões

Referências

Bibliográficas

Anexo
2

4

5

6

6

7

16

42

70

118

125

129 


\section{INDICE}

INTRODUÇÃ

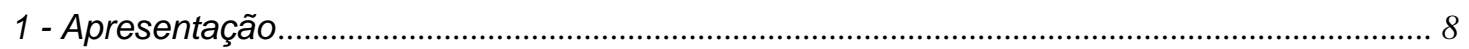

2 - Partindo da Tríade: Técnicas, Espaço e Tempo ................................................................... 10

3 - Relacionamento Espaço-Técnica: Por que estudar a Internet? ............................................. 12

4 - Por uma Periodização da Internet no Território ........................................................................ 15

CAPÍTULO I - O PERÍODO TEÓRICO-EXPERIMENTAL (1962-1974) ........................................................... 16

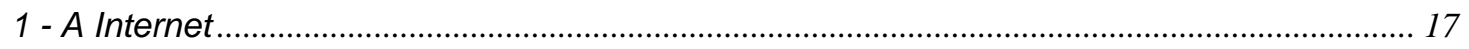

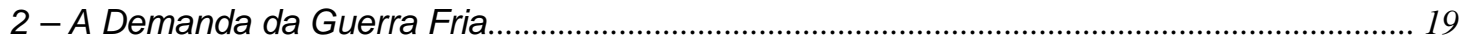

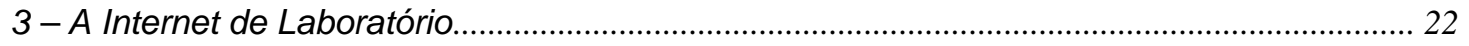

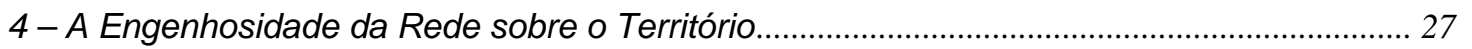

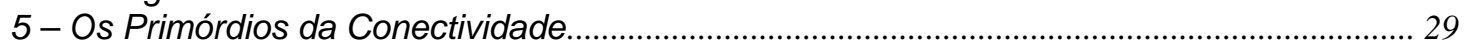

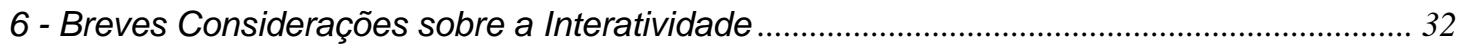

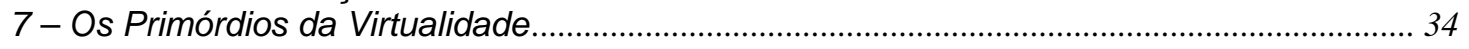

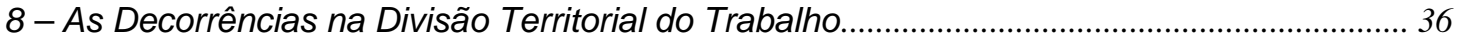

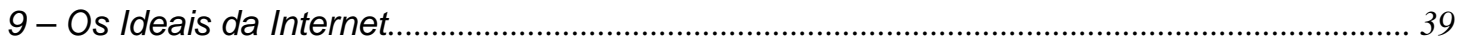

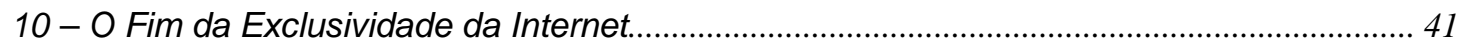

CAPÍTULO II - O PERÍODO DA NORMATIZAÇÃO E DA INTERNACIONALIZAÇÃO (1975-1991) ... 42

1 - A Consagração de Normas de Comunicação pela Rede ........................................................ 43

2 - O Surgimento da Micro-computação ....................................................................................... 45

3 - A MILNET, e a gradativa passagem para o predomínio civil da Rede: Implicações na

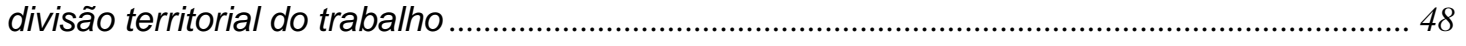

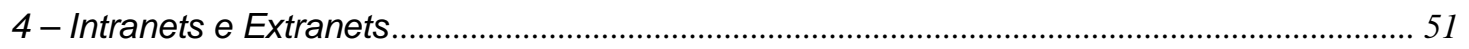

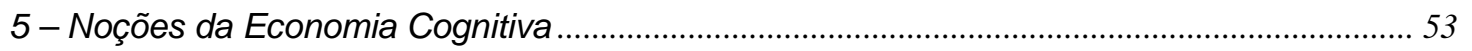

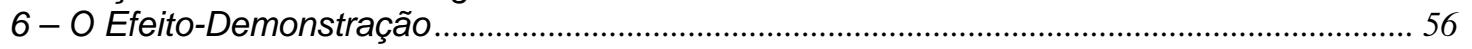

7 - Super-estradas da Informação e Aldeia Global ...................................................................... 58

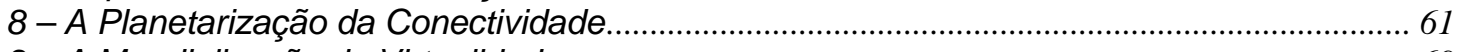

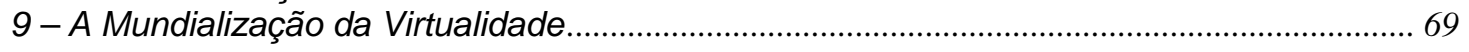

CAPÍTULO III - O PERÍODO COMERCIAL E DAS ASSIMILAÇÕES (APÓS 1991)................................. 70

1 - Sistema de Comunicação, de Transporte ou uma Entidade Sincrética?................................. 71

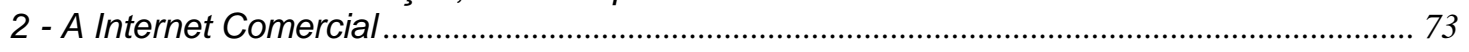

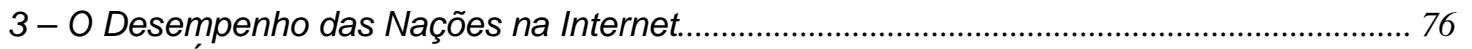

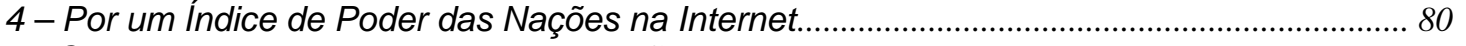

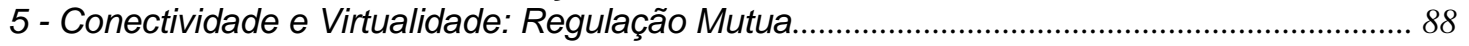

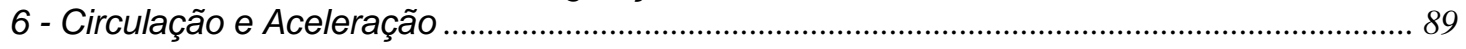

7 - A Circulação das Finanças, e a Correlação de Comportamento das Bolsas de Valor no

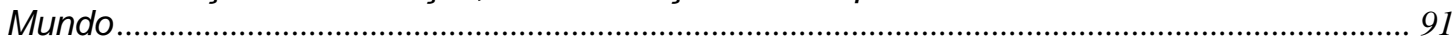

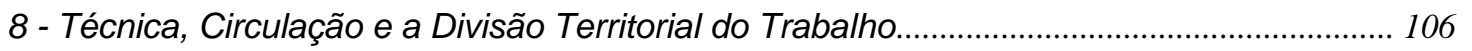

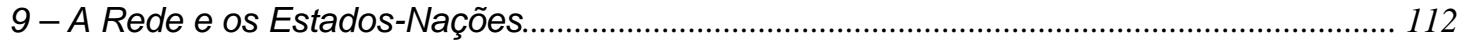

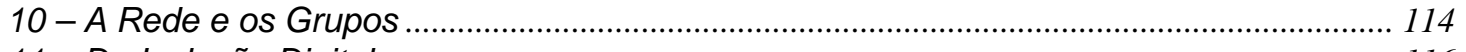

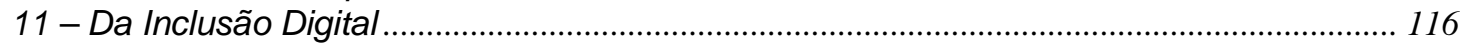

CONCLUSÕES: A UNICIDADE TÉCNICA, SOB A ÉGIDE DA INTERNET E OS IMPACTOS NA ORGANIZAÇÃO E ORDENAÇÃO TERRITORIAL ............................................................................................... 118

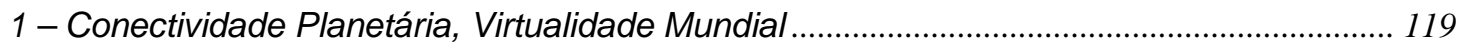

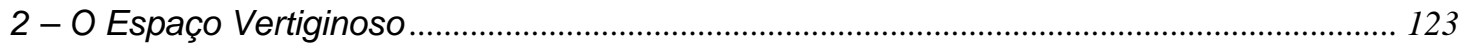

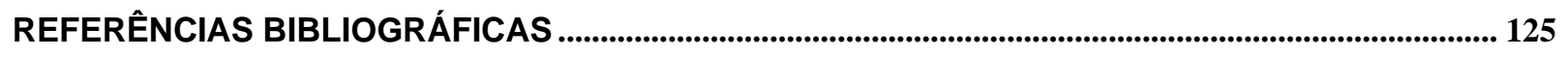

ANEXO - QUESTIONÁRIO SOBRE MEIOS E MODALIDADES DE COMUNICAÇÃO........................... 129 


\section{INDICE DAS TABELAS}

Tabela 1 - ÍNDICE DO PODER PERCEPTÍVEL NO MEIO TÉCNICO-CIENTÍFICO-

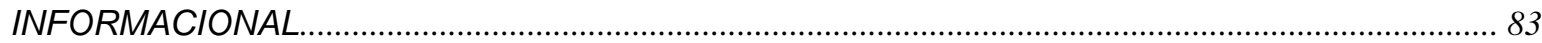

Tabela 2 - RELAÇÃO DAS BOLSAS DE VALOR UTILIZADAS NOS TRABALHOS DE

CORRELAÇÃO. 94

Tabela 3 - MAIORES EIXOS DE CORRELAÇÃO POSITIVA (01/1990-11/2004)............................. 95

Tabela 4 - MAIORES EIXOS DE CORRELAÇÃO NEGATIVA (01/1990-11/2004)............................. 96

Tabela 5 - MAIORES EIXOS DE CORRELAÇÃO POSITIVA, AMÉRICAS (01/1990-11/2004)........ 96

Tabela 6 - MAIORES EIXOS DE CORRELAÇÃO POSITIVA (04/1993-04/1996)............................... 97

Tabela 7 - MAIORES EIXOS DE CORRELAÇÃO POSITIVA (11/1996-08/1997)............................... 98

Tabela 8 - MAIORES EIXOS DE CORRELAÇÃO POSITIVA (12/1997-12/1999)............................... 99

Tabela 9 - MAIORES EIXOS DE CORRELAÇÃO POSITIVA (12/1997-12/1999).............................. 100

Tabela 10 - MAIORES EIXOS DE CORRELAÇÃO POSITIVA (09/2001-11/2004) .......................... 101

Tabela 11- EIXOS DE CORRELAÇÕES POSITIVAS E NEGATIVAS ESTUDADOS NO

DECORRER DE EVENTOS HISTÓRICOS RELEVANTES: QUANTIDADES DE CORRELAÇÕES

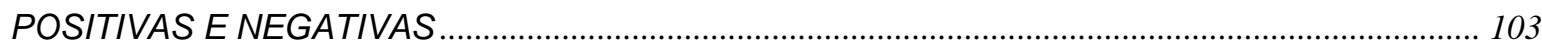

Tabela 12 - EIXOS DE CORRELAÇÕES POSITIVAS E NEGATIVAS ESTUDADAS NO

DECORRER DE EVENTOS HISTÓRICOS RELEVANTES: CONTINENTES E CIDADES ............. 104 


\section{INDICE DAS FIGURAS}

FIGURA 1 - ESQUEMAS DO ARTIGO DE PAUL BARAN. FONTE: RAND, 1964 23

FIGURA 2 - ILUSTRAÇÃO ORIGINAL DE JUNHO DE 1970, DEMONSTRANDO O ALCANCE DA ARPANET NOS EUA (FONTE: http://som.csudh.edu/cis/lpress/history/arpamaps/)... 31

FIGURA 3 - UMA CAPA DE REVISTA DE 1994, COM A PRINCIPAL REPORTAGEM FAZENDO UMA APOLOGIA DAS DIVERSAS FACILIDADES QUE A INSTAURAÇÃO DE UMA SUPERESTRADA DE INFORMAÇÃO PODE TRAZER. CRIA INCLUSIVE UM PARALELO COM A

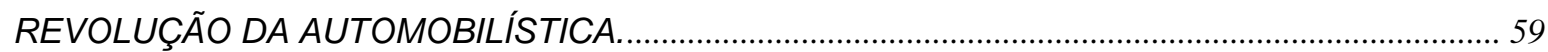
FIGURA 4 - PAÍSES PARTICIPANTES DA ARPANET E DA CYCLADES....................................... 62

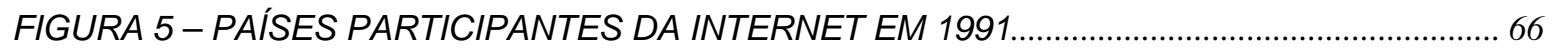
FIGURA 6 - QUANTIDADE DE EIXOS DE CORRELAÇÃO ACIMA DE 85\% EXISTENTES EM CADA PERÍODO (04/1993-11/2004). 


\title{
RESUMO
}

A presente dissertação visa estabelecer que a Internet, enquanto técnica participa da constituição territorial, nesse sentido, colabora na regulação da vida humana. Busca-se, neste projeto, compreender as relações entre o desenvolvimento da Internet $\mathrm{e}$ seus impactos na organização e ordenação territorial.

\begin{abstract}
This dissertation seeks to establish that the Internet, as a technique, takes part in the territorial constitution, in this sense, collaborating on the regulation of human life. This project will

pursue the comprehension of the relationship between the development of the Internet and its impacts on the organization and arrangement of the territory.
\end{abstract}

\section{PALAVRAS-CHAVE/KEY WORDS}

Conectividade - Virtualidade - Informação - Território Internet

Connectivity - Virtuality - Information - Territory Internet 


\section{INTRODUÇÃO}




\section{1 - Apresentação}

O meio técnico-científico-informacional resulta de uma metamorfose no Capitalismo, que conduziu a informação à condição de paradigma da história recente $^{1}$. Nesse sentido, a informação é a componente que desfechou a globalização. Após os anos da Segunda Guerra Mundial (1939-1945), a informação deixou de ser um acessório e tornou-se um fator central da existência de diversos objetos técnicos, bem como causa do despertar das ações que thes permeiam. A Internet é uma decorrência do fato de que a informação tornou-se "o vetor fundamental do processo social" (Milton SANTOS, 1996, pg. 191), no atual período em que vivemos. Diante dessas constatações, buscaremos compreender as relações entre o desenvolvimento da Internet e seus impactos na organização e ordenação do território.

Este projeto tem como alvo o meio mais fluido concebido pelo homem, a virtualidade. Pode-se circular pela virtualidade, contudo, de forma projetiva, ou, como o nome já diz, de forma virtual. Por excelência, a virtualidade foi criada para permitir que as ações se tornem mais assertivas, rápidas e com a intenção de serem infalíveis. Ainda que dispense um apelo mais intenso às modalidades da circulação física, a virtualidade jamais será exclusiva, pois não há civilização baseada apenas nas ações, mas na relação de normatização mutua entre estas e os seus objetos. Até hoje, ninguém conseguiu desvincular, em laboratório algum do Mundo, um contexto histórico da sua espacialidade, essência de toda e qualquer civilização existente. Só se escreve a história através do resgate da sucessão dos modos de produção material, isto é, pela compreensão de como e por quem as técnicas estão sendo empregadas na estruturação da divisão do trabalho. Isto vale dizer que a especificidade hierárquica e, por conseguinte, dos nexos entre as diversas técnicas existentes, conforma um caráter próprio de um período histórico. Nesse sentido, cada período possui objetos e ações peculiares,

\footnotetext{
${ }^{1}$ A evolução histórica, que conduz a este período contemporâneo é apresentada de forma instigante pelo saudoso professor Milton Santos, em seu livro "A Natureza do Espaço" (1996).
} 
que se caracterizam e se regulam mutuamente, e, sob esse ponto de vista, encerram um segmento distinto na história.

Há que se considerar, contudo, que para viabilizar ações através da virtualidade, há que se constituir uma base física, material, isto é, uma conectividade. Esta é formada por um sistema de engenharia que Ihe dá condições de existir. O sistema de engenharia ao qual referimo-nos é a Internet.

A Internet, assim como todos os sistemas de engenharia, se apresenta como um esquema de pontos interligados através de eixos imperativos, isto é, conforme uma confluência de intencionalidades, e que se dispõe como recurso das ações. Havendo uma confluência de intencionalidades na construção dos eixos, há, também, uma eletividade nos seus usos e usuários. A Internet é, portanto, a normatização da virtualidade contemporânea.

A virtualidade nos dá a impressão de que as ações perdem o atrito com o espaço e o tempo de forma definitiva, permitindo conclusões apressadas de que a Geografia e a História sejam tidas como ciências relegadas ao passado. Esse ponto de vista consiste em um perigoso reducionismo da realidade, em que se supõe uma crescente impossibilidade de sobrevivência sem a virtualidade. De fato, o que parece ter ocorrido, é uma aceleração do tempo, enquanto o espaço se tornou vertiginoso. 


\section{2 - Partindo da Tríade: Técnicas, Espaço e Tempo}

Sob um contexto histórico e político (este destacadamente no sentido da regulação territorial) qualquer, os sistemas técnicos disponíveis definirão como os integrantes de uma sociedade trabalha, e, por conseguinte, como as relações concretas (materiais ou não) se dão. Neste sentido, o sistema técnico estabelece a divisão do trabalho, bem como esta se configurará no território (a divisão territorial do trabalho). Cada lugar acumula técnicas e tecnologias (os objetos) de maneira própria, e, por conseguinte, emana e recebe ações específicas em sua relação com o restante dos lugares. As ações criam, fortalecem, perpetuam ou boicotam os objetos. Os objetos, por sua vez, constituem normas para as ações que atingem os lugares. A relação entre objetos e ações engendra, dessa maneira, temporalidades peculiares, isto é, uma variação própria dos adventos nos lugares. Nesse sentido, as ações e os objetos geram uma configuração específica (Milton SANTOS, 1994 e 1996), e assim os lugares podem ser circunscritos como frações do espaço, e diferenciados dos demais.

Uma técnica pode ser entendida como um instrumento, um meio ou forma de trabalho (Milton SANTOS, 1994, pg. 61). As técnicas possuem idades (inserção na história), distribuições e tipologias variadas (Milton SANTOS, 1994, pg. 62). Existem técnicas antigas e outras modernas. Estas podem se distribuir de forma concentrada ou dispersa, e de maneira extensa ou densa. A tipologia das técnicas varia em proporção e qualidade tanto quanto às possibilidades de atividade humana existentes em um período histórico.

O que caracteriza e distingue os lugares entre si é o conjunto das técnicas circunscritas em um convívio funcional (contexto operacional) e relacional (contexto sócio-espacial) específico, devido à variada distribuição destas pelo território. Conforme o contexto histórico, os convívios funcional e relacional podem mudar radicalmente, ou permanecerem os mesmos. Portanto, uma parcela 
coerente do espaço consiste na circunscrição de um conjunto de técnicas sob condições históricas específicas de convívio e combinação².

Para se compreender a gradual instalação (ainda que cronologicamente rápida) da Internet ${ }^{3}$ e o seu papel sob os preceitos históricos e espaciais da Globalização, é necessária a compreensão dessa relação tríplice entre técnicas, espaço e tempo. A Internet influiu e se adaptou nos lugares em que foi implantada ao longo de sua existência. Como demonstraremos nesta dissertação, a Internet obedeceu e sempre obedecerá a preceitos históricos. A Internet não é a mesma, comparando seu estado hoje com os seus primórdios, e no futuro também será diferente. Mas a técnica é, em essência, a mesma, pois o conceito permanece o mesmo. O que varia são as suas aplicabilidades e a sua pertinência, isto é, sua relação com as demais técnicas existentes nas diversas sociedades do mundo, dentro de sucessivos períodos históricos.

É essencial não se perder de vista que, como pano de fundo da inserção da Internet, ocorreu uma evolução do meio técnico-científico, que no decorrer do século XX foi acrescida de uma nova e poderosa vertente à sua lógica: a informacional (Milton SANTOS, 1994). A participação da Internet nessa evolução é fundamental, e é o que veremos ao longo da periodização que ora propomos.

\footnotetext{
2 “...o conhecimento dos sistemas técnicos sucessivos é essencial para o entendimento das diversas formas históricas de estruturação, funcionamento e articulação dos territórios, desde os albores da história até a época atual" (Milton SANTOS, 1996, pg. 137).

${ }^{3}$ A Internet é um conjunto de objetos técnicos que lidam de forma peculiar com a circulação de informações, portanto, entenda-se como um sistema técnico.
} 


\section{3 - Relacionamento Espaço-Técnica: Por que estudar a Internet?}

O nosso interesse pela Internet surgiu a partir da edição de uma revista da Bloch Editores, chamada "Conecta". A capa trazia consigo uma caricatura do bilionário Bill Gates, e uma reportagem de capa sobre o que se chamava de "Efeito Cocoon", donde "cocoon" é a palavra em Inglês para casulo. Aprendemos, nessa ocasião, que o "Efeito Casulo" consiste em uma tendência que se detectou em algumas parcelas da sociedade estadunidense, e caracterizava-se pelo isolamento social das pessoas na medida em que o uso da Internet dispensava o deslocamento físico para o exercício de algumas tarefas, como, por exemplo, trabalhar, ir ao banco ou ao supermercado. A expansão da Internet levou essa mesma preocupação para outros países do mundo, não tardando em chegar ao Brasil. De todo modo, lá pelos idos de 1996, todos que vinham acompanhando essa situação (nós, inclusive) percebiam que os motivos para acreditar no efeito casulo pareciam somente se reforçar, já que o comércio eletrônico expandia-se cada vez mais e de forma vertiginosa. Muitos estabelecimentos comerciais, como pizzarias, lojas de departamento, livrarias, entre outros, adotaram a Internet. Os serviços também passaram a atender através da Internet, como os bancos e até agências de emprego. Já havia, inclusive, estabelecimentos que somente operavam pela rede mundial, a exemplo da Amazon Books. Assim, teoricamente, cada vez menos as pessoas teriam motivos para saírem de casa e, portanto, dispensariam o deslocamento em busca desses diversos serviços. Estabelecemos, assim, uma primeira relação entre espaço e a técnica, com a seguinte pergunta: Que impactos a Internet causa sobre a organização e o ordenamento do espaço geográfico, considerando que, em certa medida, esse novo sistema técnico tentaria dispensar a circulação física?

As nossas primeiras indagações partiam da tentação de crer que o descarte da circulação física seria feito em evolução linear, até mesmo inevitável, algo que iria abarcar a vida das pessoas mais cedo ou mais tarde. Certamente, isso não era um raciocínio correto, visto que as sociedades são estratificadas em diversos aspectos, seja economicamente, politicamente, culturalmente e, inclusive, no que 
concerne à visão de mundo e à própria circulação. Considerar a possibilidade de não haver circulação física no futuro seria o mesmo que fazê-lo com o espaço. Já presumíamos, em nossas primeiras especulações a respeito do tema, que a democracia não perduraria simplesmente através do amplo uso do computador, pois isso seria uma visão perigosa e inconseqüente. $O$ aparelho computador veicula a informação, mas é o julgamento humano que a torna um aparato do conhecimento, e, assim, da democracia. Para ser pianista, não basta ter um piano, é preciso saber tocá-lo. A informação per se não conduz à democracia, mas deve ser utilizada para despertar, através da educação, a consciência, o pesar, a reflexão e a dialética, estes sim os instrumentos de uma mentalidade democrática. Se não entendermos assim, estaríamos confundindo difusão com democracia. Toda técnica "democratizada" (difundida) de fato constitui uma imposição aos indivíduos, devido ao ostensivo discurso da sua indispensabilidade ${ }^{4}$. Imaginamos que um dos princípios da liberdade do indivíduo seja o da escolha entre se integrar de uma forma ou de outra ao mundo que o cerca.

De modo algum a Internet dispensa as visões de mundo ou o deslocamento físico. Quanto mais ampla a rede, maior a probabilidade de contato com a diversidade de opiniões, o que resulta em inúmeras outras derivações. Entre outras atividades, o lazer sempre será uma causa importante do deslocamento das pessoas, ainda que esse aspecto também tenha sido incorporado, em parte, pela Internet. Contudo, ainda assim, vale ressaltar as nossas primeiras indagações quanto àquela tendência que observávamos: Como uma cidade, a exemplo de São Paulo, receberia os impactos da Internet considerando a perspectiva do "efeito casulo"? Será que o "efeito casulo" revolveria a circulação física na cidade (tendo em vista os sistemas de transporte e a lógica automobilística)? Tais perguntas poderiam ser extrapoladas, sem dúvida, para o território brasileiro ou até para outras partes do Planeta, mas não havíamos pensado nisso nas primeiras formulações.

Ainda assim, a perspectiva de um impacto da Internet sobre os diversos sistemas de circulação de uma cidade como São Paulo parecia instigante, e desencadeou

\footnotetext{
${ }^{4}$ Lembremo-nos daquilo que Karl Marx (1818-1883) chamava de "novas necessidades": são as necessidades que não são "do estômago" (limitadas), mas são todas as criações materiais e imateriais do homem (ilimitáveis).
} 
nosso interesse por compreender melhor as discussões sobre a circulação na Geografia. Instintivamente, uma das primeiras formas de encararmos a Internet foi, exatamente, como um sistema de circulação que eventualmente competisse com formas convencionais de transporte (de pessoas e de materiais), como a ferrovia ou o automóvel.

Sob essa perspectiva e pela ótica dos atores hegemônicos, poderíamos ser audaciosos em enunciar que o trem substituiu a tropa de burros, o automóvel superou o trem, e, aparentemente, o computador está vencendo, em certos aspectos, o automóvel. $\mathrm{Na}$ época, nós não nos perguntávamos se isso procedia ou se consistia em discurso. O tempo parece nos ter mostrado que o computador serviu para poupar a circulação, aperfeiçoá-la.

O fato é que, na ocasião das nossas primeiras indagações, tínhamos ainda menos clareza em relação ao papel do computador. Confessamos que havia um grau de cegueira resultante do brilho encantador de suas possibilidades. Enxergávamos a Internet como panacéia, e não como um mero instrumento. Ainda que a Internet tenha inibido parte dos deslocamentos até então necessários, não se pode ser ingênuo a ponto de acreditar que o automóvel sucumbirá em breve em função disso. Sequer poderíamos supor que o computador teria tal pretensão.

Desde 1996, utilizamos pessoalmente a Internet como instrumento de pesquisa, comunicação, consumo e lazer. Nossa duradoura relação com a Internet nos despertou para diversas perguntas, divergências com a abordagem exclusivamente técnica ou com a mentalidade de Panacéia. Ainda antes disso, por volta de 1994, enquanto usuários de BBS (bulletin board systems) ${ }^{5}$, já nos perguntávamos onde isso iria nos levar. A nossa própria condição pessoal de usuário despertou nosso interesse pelo estudo.

\footnotetext{
${ }^{5}$ Eram sistemas caseiros, que permitiam várias modalidades iguais às da Internet, como a transferência de arquivos, divulgação de informações e a interlocução entre as partes. Uma BBS corresponderia a um sítio de Internet, contudo isolada das demais BBS. As BBS possuíam, na maioria das vezes, uma temática (adulto, jogos eletrônicos, grupos profissionais etc.), e se comportavam como sítios.
} 


\section{4 - Por uma Periodização da Internet no Território}

Uma análise adequada de qualquer processo de caráter histórico requer o reconhecimento de durações e das suas rupturas. Para compreender como a Internet surgiu e evoluiu para o estágio atual foi necessário estabelecer uma periodização. A atitude de periodizar permite ao pesquisador um resgate coerente de como o processo se desencadeou ao longo do tempo. Esse resgate coerente deve considerar as características próprias de cada fração do tempo, do ponto de vista de uma parcela ou de todo um conjunto técnico. Trata-se de estabelecer os principais aspectos que conduziram um contexto pretérito à atualidade.

A Internet originou-se com outro nome (Arpanet) e com finalidade diferente do que hoje conhecemos. Efetivamente, a grande rede havia sido concebida, originalmente, do mesmo modo como muitos dos objetos mais banais de nosso cotidiano, para fins militares. Assim como a margarina vegetal foi concebida para a lubrificação barata de hélices de aviões e helicópteros, e hoje a comemos como alternativa à manteiga, a Internet também teve uma concepção militar, e uma transposição de utilidade para o comércio e os serviços civis.

Contudo, nossa periodização deve ser coerente também com nossa "província do conhecimento", a Geografia. Isto significa dizer que a periodização deve levar em conta as categorias da disciplina, sem as quais apresentaríamos um trabalho

árido, cheio de definições de ordem tecnológica, e voltado apenas para o conhecimento enciclopédico. Nesse sentido, é central expressarmos no decorrer das periodizações, e na própria caracterização destas, em que sentido o espaço foi afetado. Cada período pode ser interpretado como um contexto técnico, porém, relacionado intimamente a um contexto sócio-espacial. 


\section{CAPÍTULO I - O PERÍODO TEÓRICO-EXPERIMENTAL (1962-1974)}




\section{1 - A Internet}

A Internet é, provavelmente, uma das conseqüências mais duradouras, poderosas e profundas que a chamada "Guerra Fria" (1945-1989) nos deixou de legado. O desenvolvimento do conceito da Internet é uma derivação, uma conseqüência histórica, da constante necessidade, proveniente das primeiras aglomerações humanas da história, de conduzir a informação para o próximo, tendo em vista um interesse qualquer (interesse aqui nem sempre no sentido exploratório, podendo ser associativo, isto é, visando um interesse comum). A comunicação é um componente essencial das sociedades, pois é através do desenvolvimento da linguagem e de seus aparatos que se tornou possível elaborar a diversidade e a complexidade, bem como os benefícios e os malefícios que lhes caracterizam.

Vale ressaltar a diferença entre propagação e comunicação. A propagação é uma modalidade própria do meio físico. O ato de propagar é causar a emissão de algum tipo de interferência (ondas sonoras, eletromagnéticas etc.) nas instâncias do meio físico (ar, água etc.), contudo, independente de qualquer intenção ou escopo. É uma relação estudada pelos cientistas da natureza pura. A comunicação, contudo, é modalidade própria do espaço. $O$ ato de se comunicar impreterivelmente envolve linguagem, intenção e interatividade, conectividade e virtualidade. A comunicação possui finalidade, envolve relações entre dois ou mais seres humanos, isto é, trata-se de uma interlocução. As ações são desencadeadas pela comunicação. Esta é uma relação social, histórica e, por conseguinte, influente no arranjo relacional das ações e dos objetos.

Nesse sentido, é fundamental pressupor que o âmbito em que a comunicação se "propaga" é o espaço (não o meio físico), seja através da voz, do gesto, da literatura, dos pulsos ou dos meios eletrônicos. A comunicação congrega uma série de técnicas, com elaboração diretamente subordinada aos preceitos do período histórico em vigor, mas que atinge de forma diferenciada os diversos lugares, por conta das diversidades locais. A conectividade é desigual entre os lugares. Abraçando a definição do saudoso professor Milton Santos, de que o espaço constitui-se de um conjunto indissociável de ações e objetos (Milton SANTOS, 1996), e que é por meio dessa relação propulsada pela evolução 
técnica que se faz a história, pode-se vislumbrar que o espaço é desigual, pois nem todas as ações atingem todos os objetos existentes em todos os lugares. Por conta disso, ainda que o paradigma da comunicação seja mundial, o modo pelo qual se recebe ou se retransmite é diverso tanto quanto forem as culturas e as sociedades existentes no Planeta. 


\section{2 - A Demanda da Guerra Fria}

O período se caracteriza pela implantação, em caráter experimental, dos conceitos que dão base para a evolução posterior da Internet. A rede já estava criada em 1970, porém, até 1972 podemos considerá-la como incipiente e apenas um ensaio. Entre 1972 e 1975, diversos experimentos foram feitos com a rede que se desenvolvia. Este período estende-se de 1964, ano em que o engenheiro elétrico Paul Baran lançou seu artigo revolucionário sobre as redes distribuídas (redundantes), e termina no ano de 1975, ano do surgimento do protocolo TCP/IP e de fundação da empresa Microsoft.

O contexto era o da Guerra Fria (termo cunhado por Bernard Baruch, em 1947). Os Estados Unidos e a União Soviética empenhavam-se na ameaça de destruição mútua e garantida através de quantidades maciças e sempre crescentes de armas nucleares. Por mais contraditório que pareça, essa ameaça estabelecia um razoável engessamento, que perpetuava a manutenção de uma paz tensa, armada e com conflitos que eventualmente extravasavam esse antagonismo. Havia, portanto, uma dispendiosa corrida armamentista, tida como necessária para manter esse equilíbrio geopolítico, também conhecido como "equilíbrio do terror". Além das armas nucleares, a chamada Guerra Fria também foi uma competição do ponto de vista das técnicas de sobrevivência e de superação das dificuldades eventualmente geradas pelo desfecho de um confronto militar direto. Num conflito nuclear entre as duas chamadas superpotências (expressão cunhada por William Fox, em 1943), quem saísse menos destruído e com os centros de comando e de controle (político, militar, acadêmico e econômico) menos prejudicados, já poderia se declarar vencedor. O constante acúmulo de recursos desse tipo, isto é, de sobrevivência à guerra nuclear iminente, já fazia a balança pender a favor de um ou de outro.

Em 1962, com o advento da instalação de mísseis nucleares e bombardeiros soviéticos em Cuba, os EUA e a União Soviética estiveram muito próximos de um conflito de proporções mundiais. A liderança soviética, então encabeçada por Nikita Sergei Khrushchev, estreitou laços com o país liderado por Fidel Castro, em 
busca de uma vantagem geopolítica na esfera de influência imediata dos EUA. Até então, a vantagem num eventual conflito parecia pender para os EUA, que, utilizando-se das alianças na Eurásia, criou um cinturão de bases aéreas e de lançamento de MRBMs (Mísseis Balísticos de Médio Alcance) em torno da União Soviética, numa política clara de contenção. Em 14 de outubro de 1962, os serviços de espionagem por aerolevantamento (chamado de IMINT, ou Image Intelligence) dos EUA detectaram a operação de instalação dos aparatos soviéticos em Cuba. O então presidente dos EUA, John Fitzgerald Kennedy, optou pela imposição de um bloqueio naval ostensivo em torno da ilha, de modo a forçar a retirada dos aparatos soviéticos que ali estavam. O impasse acabou sendo resolvido finalmente, em 28 de outubro de 1962, com a retirada dos equipamentos hostis de Cuba, em troca da retirada de aparatos correlatos, pertencentes à OTAN situados em território da Turquia. Sabe-se hoje que, no decorrer dos quatorze dias desse impasse, os governos da União Soviética e dos Estados Unidos estavam praticamente incomunicáveis. Qualquer atitude interpretada como hostil poderia ter desencadeado um conflito sem precedentes na história humana. Pouco mais de 40 dias depois da chamada Crise dos Mísseis de Cuba, em 12 de dezembro de 1962, uma linha telefônica dotada de técnicas de criptografia foi concebida e ratificada pelo presidente Kennedy, em acordo com o líder Khrushchev, para ligar diretamente os dois centros de poder em Washington e Moscou. Em meados de 1963, essa linha, chamada de "linha vermelha" (do inglês red line), já estava em atividade e foi revelada ao mundo. Criou-se um mecanismo para evitar e, eventualmente, sobreviver quaisquer conflitos no futuro.

A criação de mecanismos que sobrepujassem um conflito iminente se fez necessária, principalmente após 1949 (ano em que a União Soviética revelou ao mundo a sua primeira bomba nuclear), pois havia uma razoável probabilidade de ser nuclear. Para garantir a sobrevivência das instituições nacionais foram criados os chamados "think tanks". Esse apelido poderia ser traduzido como "reservatórios de idéias ou do pensar". Um desses reservatórios seria a RAND Corporation, uma instituição voltada para elaborar soluções diversas para a sociedade e as instituições privadas e públicas dos Estados Unidos em geral. Para se ter noção 
da capacidade desses "reservatórios", em maio de 1946, o primeiro ensaio lançado sob a égide da RAND tratava da viabilidade e aplicabilidade de satélites orbitais feitos pelo homem, bem como das possibilidades de estruturação desses equipamentos. Este ensaio foi feito onze anos antes do Sputnik (União Soviética, 1957), o primeiro dos satélites artificiais. Até então, o conceito dos satélites era escopo dos autores de ficção científica, principalmente nos livros de Arthur $\mathrm{C}$. Clarke e de Isaac Azimov. A RAND visa, até os dias de hoje, e nos diversos campos do conhecimento, a aplicabilidade de conceitos de vanguarda para o benefício das instituições dos EUA, abrangendo estudos avançados em diversas áreas, desde relações internacionais até ciência e tecnologia.

Desde a crise dos mísseis soviéticos em Cuba, todos esses "reservatórios", inclusive a RAND, se envolveram na elaboração de estratégias para a sobrevivência institucional no advento de um confronto nuclear entre as superpotências. Uma das maiores preocupações do governo envolvia a garantia de circulação de informações e de dados entre as instituições chave da sociedade estadunidense. Era preciso um mecanismo de interlocução eficaz, com possibilidades diversas e simultâneas de comunicação entre instâncias e entidades consideradas vitais para o funcionamento dos EUA (chefes da administração, de defesa e as universidades), muitas vezes distantes milhares de quilômetros. As diversas instâncias e entidades encontravam-se parcialmente dispersas pelo território estadunidense, e a idéia de um meio de comunicação que não fosse destruído por um conflito nuclear seria, naturalmente, fundamental para garantir o controle do país. Em suma, visava-se garantir a sobrevivência do Estado e das instâncias fundamentais que a legitimam, mesmo depois de uma catástrofe nuclear. 


\section{3 - A Internet de Laboratório}

Desde 1959, após a aquisição do título de mestre em engenharia elétrica, o estudioso Paul Baran, de ascendência polonesa, havia se tornado pesquisador associado à RAND. Nessa época, ele, a exemplo de uma considerável porção de pesquisadores associados, via-se diante de um desafio complexo: os centros de comutação (os chamados "switching centers", conhecidos também como centrais de comutação) representam, simultaneamente, foco (receptáculo) e pólo (difusor) no envio e repasse de informações em uma estrutura de rede convencional. A concentração dessas instalações constituía alvos fáceis para um avião bombardeiro, e, qualquer informação considerada vital corria risco de ser perdida, visto que a trajetória da informação era linear (emissor e receptor ligados por apenas uma trajetória). A informação, portanto, poderia estar sendo comutada, justamente, numa central sob ataque inimigo. A proposta de Paul Baran foi inédita ("On Distributed Communications Networks", artigo publicado pela RAND em 1964), pois burlava a arquitetura centralizadora das redes, com a utilização dos conceitos de redundância e comunicação distribuída, sob a bandeira da tecnologia digital. Ele propôs uma estrutura de rede mais robusta, sem controle humano direto, e com encaminhamento redundante e roteado através de uma malha de nós pulverizados pelo território. A informação, portanto, não é conduzida através uma rota específica, atingindo "gargalos" como centros de comutação (descentralizada, vide figura 1), mas pulverizada, sempre variável, em função da quantidade de nós disponíveis na rede. Desse modo, supondo um grande número de pontos, e que diversos desses nós fossem destruídos, aquilo que restasse ainda estaria apto a receber, repassar e a "redesenhar" a rota dos dados para garantir a comunicação entre as partes. Seria necessário destruir a rede quase por completo para inviabilizar os fluxos de informação. A comunicação passaria a ser, portanto, distribuída e redundante, pois haveriam diversos desses nós, todos aptos a lidar com a informação da mesma maneira, e com habilidade suficiente para determinar o melhor trajeto desta pela rede. Além disso, a informação seria dificilmente interceptada e jamais tenderia a ser centralizada em um só local, pois, 
ao invés de perpassar a rede como um bloco único, este seria particionado em "pacotes" menores, ou seja, fragmentos, cada qual com trajetos diversos. Atingese a redundância com a combinação destes mecanismos. Contudo, foi somente à sombra de um vistoso evento do ano de 1969, a primeira expedição para a Lua, que essas idéias de Paul Baran foram postas à prova em escala real.

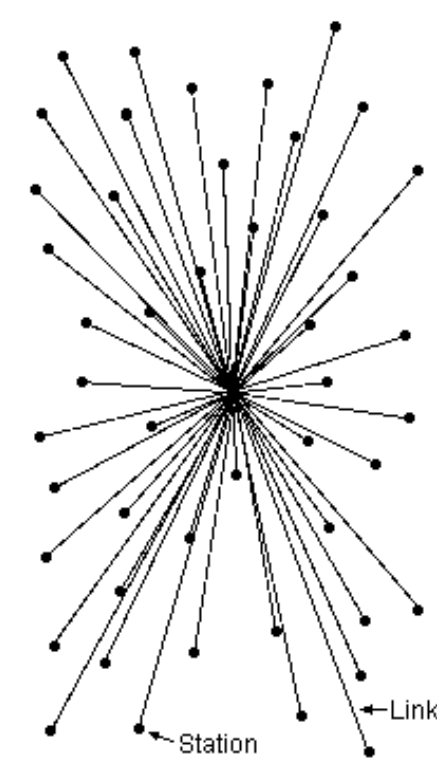

Centralizado

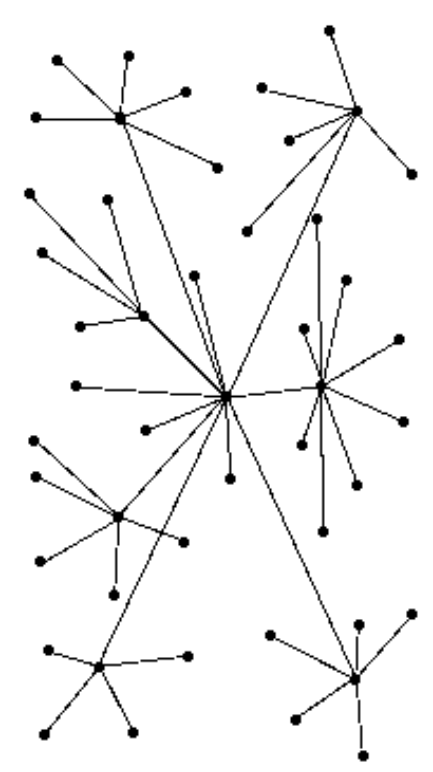

Descentralizado Redundante (Distribuído)

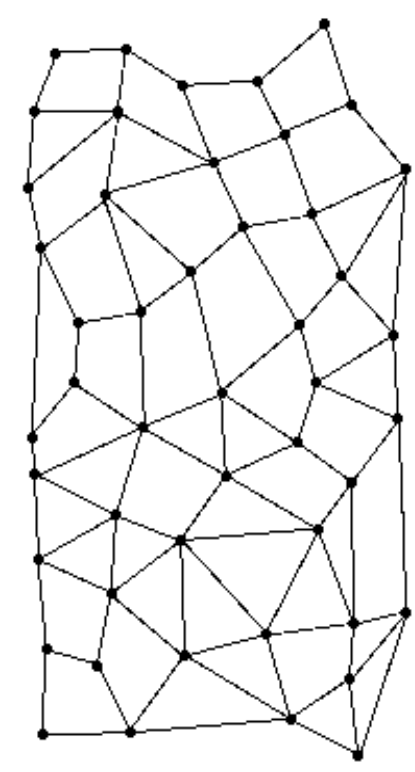

FIGURA 1 - ESQUEMAS DO ARTIGO DE PAUL BARAN. FONTE: RAND, 1964

O lançamento do Sputnik pela União Soviética, em 1957, tornou patente a necessidade estadunidense de fomentar, com urgência, o desenvolvimento tecnológico com ênfase nos fins militares. O objetivo seria o de promover a equiparação, e, se possível, a superação da reputação científica em que se encontrava a União Soviética dos anos 50 e 60 do século XX. Para promover esse objetivo, já em 1958, no âmbito do Departamento de Defesa dos EUA, foi criada a Agência de Projetos de Pesquisa Avançada, ou ARPA (sigla para "Advanced Research Projects Agency"). Principalmente a partir de 1962, a ARPA, através de sua Oficina de Técnicas de Processamento da Informação ("Information Processing Techniques Office", ou IPTO), passava a dedicar recursos para a 
concretização de projetos que permitissem a intercomunicação entre computadores (Arnaldo MANDEL et alli, 1997, pg. 26).

Em 30 de agosto de 1969, o Campus de Los Angeles da Universidade da California (University of California at Los Angeles - UCLA), com o apoio financeiro da ARPA, inaugurou o primeiro ponto de rede, ou "nó" ${ }^{6}$, do que se convencionou chamar de "Arpanet". Antes de junho de 1970, a RAND Corporation, sediada em Santa Monica (estado da California, EUA) local de trabalho de Paul Baran, iria ser detentora do sétimo nó dessa rede (conforme os registros disponíveis no sítio de Internet da própria instituição) ${ }^{7}$.

O contexto inicial da Arpanet é laboratorial, isto é, para todos os efeitos, encontrava-se em fase experimental, por ser ainda uma rede incipiente, primária, sem nós suficientes para ser considerada robusta e útil para atender seus objetivos práticos. Essa característica perduraria até 1975.

Segundo a RAND, em apenas dois anos de utilização (1971), a Arpanet já iria se caracterizar como um meio inédito, expedito e eficaz de interação entre pesquisadores e cientistas, entre os quinze pontos existentes. O correio eletrônico (electronic mail, ou e-mail) logo despontava como o principal motivo de utilização da Arpanet.

Conforme a "Linha do Tempo de Hobbes" ${ }^{8}$, ainda em 1971 foi inventado o primeiro programa especializado no envio de correio eletrônico através de redes distribuídas (redundantes), provavelmente, por conta da crescente demanda pelo uso da Arpanet como meio de envio de mensagens. Como conseqüência direta, isso permitiu que mais pessoas se capacitassem a enviar mensagens pela Arpanet. Essa capacitação advém da criação de programas de computador e de seus módulos (extensões de programação), que visam facilitar um conjunto de procedimentos técnicos mais extensos e complexos. Isso naturalmente gera maior

\footnotetext{
${ }^{6}$ Tecnicamente, aquilo que chamaremos daqui por diante como "nó" é um Processador de Mensagens de Interface, do Inglês "IMP" (Interface Message Processor). Cada IMP, nessa época, era capaz de interligar até quatro computadores anfitriões com até seis outros IMPs (nós da rede). ${ }^{7}$ www.rand.org/about/history/baran.html.

${ }^{8}$ Linha do Tempo da Internet de Hobbes, ou simplesmente Linha do Tempo de Hobbes www.zakon.org/robert/Internet/timeline: Trata-se de um sítio de Internet no qual se colecionam, em ordem cronológica, os eventos considerados relevantes à evolução de grande rede. Conta com diversos colaboradores, inclusive do Brasil.
} 
acessibilidade aos recursos de uma máquina, e permite o aumento no numero de usuários. Em março de 1972, conforme a Linha do Tempo de Hobbes, a sigla de arroba ("@”) é universalmente atribuída com o significado da palavra "at" ("em", na língua inglesa, para designar de qual servidor partiu uma mensagem), e em julho do mesmo ano, achou-se necessário lançar o primeiro programa de gerenciamento (com funções de listagem, leitura seletiva, repasse e resposta) de correio eletrônico. A Linha do Tempo de Hobbes ainda nos ensinou que um estudo elaborado pela ARPA, em 1973, revelou que o correio eletrônico era responsável por volta de $75 \%$ do tráfego da Arpanet.

Nessa época, ao contrário do que se possa pensar, o diálogo eletrônico escrito, amplamente conhecido como "chat" (equivalente em Inglês de "bate-papo") logo se tornaria hábito entre usuários da Arpanet. Conforme a Linha do Tempo de Hobbes, no ano de 1972, às vésperas da Conferência Internacional de Comunicação Computacional (realizada em outubro, na cidade de Washington EUA), a UCLA foi anfitriã da primeira conversa a longa distância via rede, que foi entre um paciente de psiquiatria (na Universidade de Stanford, na costa oeste dos EUA) e seu médico (na BBN - Bolt, Beranek and Newman Incorporated, em Cambridge, na costa leste dos EUA). O advento foi, conforme Arnaldo MANDEL et alli (1997, pg. 27), a primeira demonstração pública da rede. Também em 1972, a ALOHAnet, uma rede havaiana que utilizava a mesma lógica da rede da ARPA, aliada, contudo, ao uso da radiofreqüência (desenvolvida ainda em 1970 na Universidade do Havaí, EUA), passava a integrar-se à Arpanet. Em paralelo, no ano de 1972, foi criada a CYCLADES, uma concepção francesa independente e equivalente à Arpanet, e que iria contribuir (do ponto de vista puramente técnico) para o desenvolvimento da futura Internet tal qual a conhecemos hoje.

Em 1973, portanto, menos de um ano após o surgimento do diálogo eletrônico escrito, foi inventado um protocolo que permitia o diálogo eletrônico por voz, amplamente conhecido como a conferência eletrônica. Esse mesmo ano foi marcado pela integração da Noruega e do Reino Unido (junho de 1973), 
respectivamente, através da $\operatorname{NORSAR}^{9}$ e da Universidade de Londres, via NORSAR.

Em 1974, vale a pena ressaltar que a BBN, conforme consta na Linha do Tempo de Hobbes, lança uma versão comercial da Internet, chamada de Telenet. Como desdobramento disso foi a criada a primeira lista de discussão, a MsgGroup (assuntos diversos), já no ano seguinte. No decorrer do ano de 1975, foi concebida a SF-Lovers (SF vem da abreviação do Inglês science fiction, referindose a um grupo dos amantes -"lovers" - da ficção científica), que se tornaria a lista mais popular da época, de acordo com a Linha do Tempo de Hobbes. Nesse mesmo ano, foram feitos os primeiros testes com o protocolo TCP (do Inglês Transmission Control Protocol, i.e., Protocolo de Controle de Transmissão), até hoje em utilização, que permitiu a ligação através de satélites, do Havaí aos EUA continental e destes com o Reino Unido.

\footnotetext{
${ }^{9}$ A NORSAR é uma instituição sediada em Kjeller, próximo de Oslo, na Noruega. A NORSAR foi designada para monitorar o cumprimento do tratado de banimento de testes nucleares, e dedica-se a estudos que envolvem a sismologia e a geofísica. O nó que ligou a NORSAR à rede da ARPA ficava em Tanum, no oeste da Suécia, e recebia sinais de um satélite estadunidense. A ARPA instalou, em comum acordo com as autoridades da Noruega e Reino Unido, um cabo que ligava Londres a Kjeller, constituindo, ainda no ano de 1973, o primeiro nó em território britânico.
} 


\section{4 - A Engenhosidade da Rede sobre o Território}

Ainda que um conceito de "Internet" já existisse no laboratório, por volta de 1965, a primeira ação só poderia ser proferida após o desenvolvimento, adaptação ou implantação dos primeiros objetos que operacionalizassem tal ação (antenas, satélites etc.) no território (a partir de 1969). O primeiro objeto, por outro lado, foi concebido tendo em vista a necessidade de proferir ações específicas (relacionadas às atividades de segurança nacional e comunicação entre os integrantes da comunidade científica).

A Internet se tornou uma das mais poderosas modalidades que atualmente contribui para o alargamento dos contextos. Comporta-se como uma tubulação, um condutor, ou, como queira, um corredor de ações, sejam estas associadas às verticalidades ou às horizontalidades. Contudo, para alcançar esse estágio no decorrer da década de 1990, foi necessário conceber antes um conjunto técnico de suporte, isto é, infra-estruturas complexas que permitissem a sua viabilidade enquanto conceito. O governo e os militares estadunidenses, grandes empresas e instituições de pesquisa se envolveram, gerando verticalidades no território dos Estados Unidos. O crescente desenvolvimento da telefonia, o lançamento dos primeiros satélites de comunicação, o aperfeiçoamento das antenas retransmissoras e dos componentes eletrônicos em geral incrementaram as possibilidades de comunicação, permitindo o surgimento da rede, e, portanto, da interatividade. Para viabilizar um conjunto de ações possíveis, foi necessário conceber e implantar objetos que permitiam a circulação daquelas. Como veremos em breve, chamamos de conectividade aquilo que é constituído pelos sistemas de engenharia disponíveis e seus acessórios e complementos, enquanto a virtualidade é constituída pela circulação eficaz dos dados que permeiam tais sistemas. O conjunto gerado pela parceria entre conectividade e virtualidade constitui a totalidade da Internet. O período teórico-experimental é aquele de implantação e adaptação dos sistemas de engenharia ao conceito de rede distribuída e redundante. Foi, portanto, um período em que predominaram as verticalidades, visto que o pragmatismo e a racionalidade dos governantes e de 
outros atores hegemônicos da sociedade dos Estados Unidos legitimaram o investimento e a implantação do conceito no seu território. A racionalidade voltada para a sobrevivência a um eventual conflito nuclear demandou a criação de um instrumento que atendesse tal situação. Dessa maneira, o arcabouço da Internet surge a partir de uma aglutinação de interesses e de uma precipitação de verticalidades.

A engenhosidade do conjunto técnico que compõe a Internet é a sua capacidade de "burlar" as instâncias fisiológicas do território, isto é, montanhas, rios, mares, abismos e as grandes distâncias. No entanto, a Internet não supera sociedades, e apenas infiltra nos conjuntos técnicos existentes nos lugares. As sociedades e os lugares compõem o aspecto prático do território. Do ponto de vista fisiológico do território, a comunicação ambígua só faz sentido se considerarmos que a estratégia de implantação aproveita justamente da vastidão do Planeta, de modo que isso sirva para dissuadir ataques contra o sistema.

As horizontalidades estavam ainda por crescer muito somente uma década mais tarde, algo que não seria muito difícil de prever ainda naquela época. $O$ surgimento da primeira lista de discussão lançaria as bases para as mais diversas formas de associação à distância pela rede, desde aquelas voltadas para o puro lazer até as reivindicatórias e de articulação política. O mecanismo que permitiu a disseminação das listas de discussão foi o correio eletrônico. O surgimento do correio eletrônico é a experiência mais notória de todas que estão relacionadas à Internet. Ainda que tenha sido concebido para conduzir ações associadas às verticalidades, o correio eletrônico permitiu que os fluxos horizontais também fossem beneficiados. 


\section{5 - Os Primórdios da Conectividade}

O grau de conectividade, isto é, as possibilidades de comunicação, através da Internet neste período eram incipientes do ponto de vista da sociedade em geral, e inexistentes na maior porção do Planeta. Somente o governo e os militares estadunidenses, as principais universidades dos Estados Unidos e algumas poucas entidades estrangeiras e correlatas encontravam-se conectados. Pode-se dizer que a rede era, nesse período, tecnocêntrica e tecnocrática. A sociedade em geral estava isolada dessa modalidade de comunicação, e, além dessa concentração funcional, a rede ainda era pouco complexa, muito menor e mais lenta do que a de hoje. Um modem doméstico e convencional de hoje pode, tranqüilamente, ter capacidades superiores que os terminais mais importantes da Internet em 1975.

A quantidade de objetos técnicos disponíveis para efetivar toda a comunicação na rede da ARPA nos anos 70 (século $X X$ ) era menor que a que se tem à disposição hoje em apenas um município como Campinas ou São José dos Campos. Para se ter idéia do que estamos falando, em 1975 havia menos de uma centena de computadores ligados à Internet ${ }^{10}$. Hoje, em apenas um quarteirão de um bairro de classe média-alta da cidade de São Paulo podemos encontrar mais computadores do que isso. Pensemos agora na diferença de infra-estrutura de sustentação da rede, entre hoje e 1974, 1975. Neste sentido, as possibilidades de comunicação, isto é, a conectividade, nesse período experimental era muito menor que a que temos hoje.

Conforme A Natureza do Espaço, obra do saudoso professor Milton Santos (1996, pg. 190), os três períodos que descrevemos integram o tempo de consolidação do meio técnico-científico-informacional. O computador, as fibras ópticas, os satélites e as antenas retransmissoras são todos objetos técnicos, mas também são essencialmente informacionais. O motivo pelo que todos estes objetos existem é o de gerenciar, direcionar, proteger e distribuir informação. Se as instituições após a Segunda Guerra Mundial não priorizassem a informação, boa parte dos objetos

\footnotetext{
${ }^{10}$ Conforme a página da Living Internet (http://www.livinginternet.com/i/ii_Arpanet.htm).
} 
técnicos que hoje são considerados indispensáveis talvez sequer existisse. O grau de conectividade e a sua configuração (espacial e técnica) atingida em 2006 devem-se à crescente demanda dos anos passados.

A conectividade no período teórico-experimental era especializada, isto é, tinha aplicações específicas e funcionalmente bem delimitadas, justamente por estar restrita às parcelas da sociedade que a utilizava. Nesse sentido, os objetos técnicos acompanhavam esta demanda, tanto em proporção, potencialidade e restrição. Este período que optamos por chamar de teórico-experimental poderia ser chamado também de ideológico-estratégico, pois a concepção inicial da Arpanet de fato atendia uma demanda estratégica das instituições estadunidenses dos anos da Guerra Fria, tendo como finalidade última a perpetuação da liderança política e econômica no mundo de ideologia liberal capitalista. Também as instituições selecionadas e envolvidas no usufruto dessa liquidez informacional eram estratégicas. A rede possibilitou fluxos rápidos de informações entre Universidades, bases militares, o governo e outras instituições científicas. Tal articulação, por si só já era estratégica.

Ainda que atacada por bombas nucleares, a rede da ARPA possibilitava ao governo estadunidense maiores chances de sobrevivência, e, assim, poder reagir e exercer domínio sobre seu próprio território e política externa. Os contrafortes da ideologia liberal permaneceriam de pé, e poderiam reagir dentro de suas possibilidades. Isso seria um fato se a rede já nascesse densa o suficiente para atender a teoria, ou, ao menos, tivesse uma expansão inicial rápida.

Tão estratégico e, não menos ideológico, é o próprio território dos Estados Unidos. A vastidão do país permitia que se criasse a perspectiva de que se poderia coalhar o território nacional de objetos técnicos que repassassem informações, de modo que fosse praticamente impossível interromper o fluxo entre os pontos de sustentação da governabilidade. Isso, por si só é uma ideologia, e um discurso de dissuasão. O período teórico-experimental também era, nesse sentido, ideológicoestratégico. 
As modalidades, essencialmente, eram as mesmas de hoje, porém, com muitos rudimentos. Já era possível enviar e-mails (desde $1971^{11}$ ), teclar em tempo real e até mesmo fazer conferências à distância, graças à existência de tecnologias que permitiam fazer isso. Já a velocidade com que a comunicação se dava e a confiabilidade de que a comunicação iria se completar não eram as mesmas de hoje. A conectividade era feita através de um numero reduzido de objetos técnicos, e, com base nos preceitos lançados por Paul Baran em 1964, consideramos que a probabilidade de falha nesse sistema era maior.

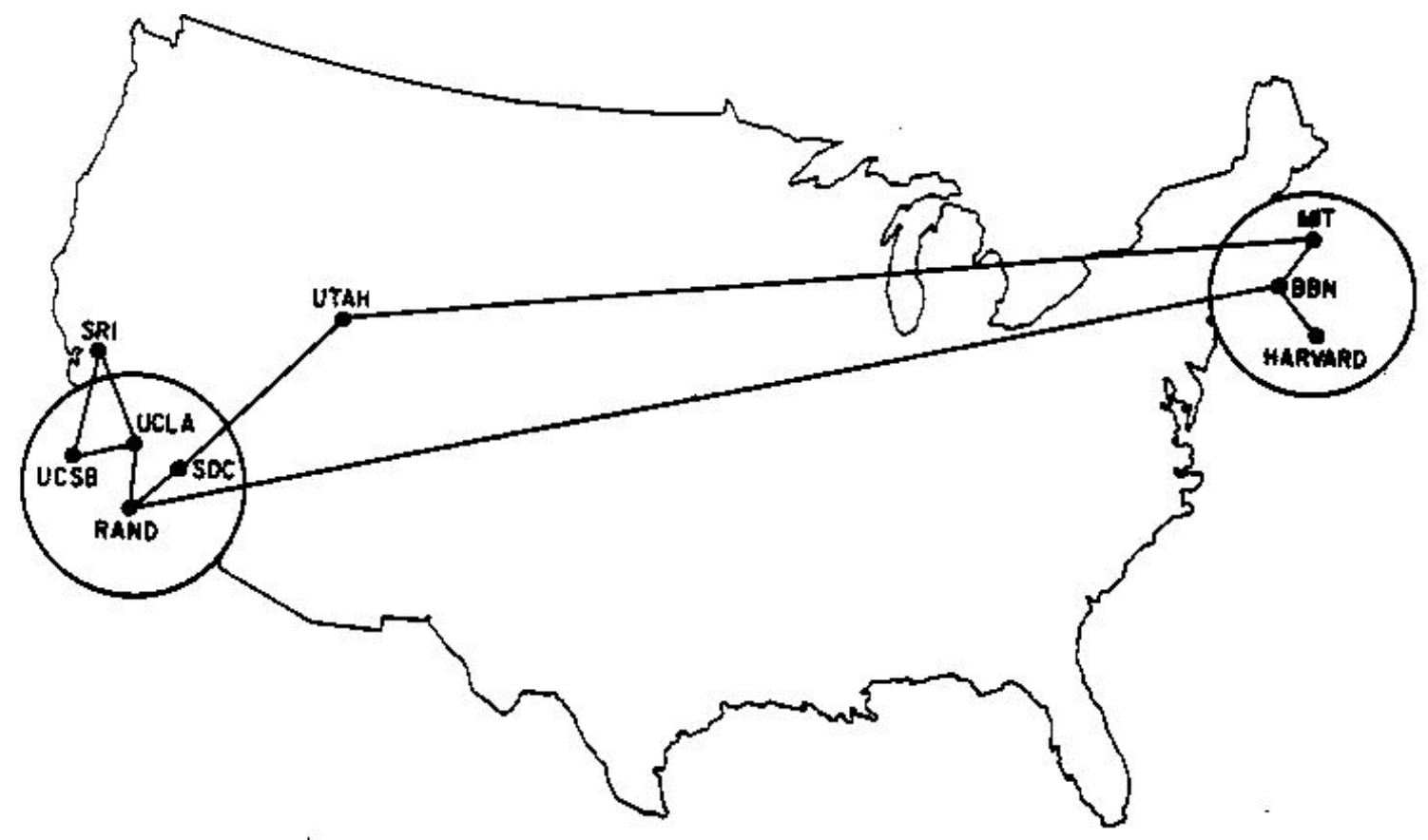

FIGURA 2 - ILUSTRAÇÃO ORIGINAL DE JUNHO DE 1970, DEMONSTRANDO O ALCANCE DA ARPANET NOS EUA (FONTE: http://som.csudh.edu/cis/lpress/history/arpamaps/)

\footnotetext{
${ }^{11}$ Conforme o capítulo 3 da página eletrônica de Richard Griffiths, na Universidade de Leiden (Países Baixos): http://www.let.leidenuniv.nl/history/ivh/frame_theorie.html
} 


\section{6 - Breves Considerações sobre a Interatividade}

Vamos distinguir o que é a interatividade real daquela que é inócua. A interatividade real refere-se, efetivamente, à interação entre duas pessoas através de um meio de comunicação. A interatividade inócua é a interação entre uma pessoa e um aparelho remoto. O uso do telefone entre dois namorados apaixonados é uma situação de interatividade real. O uso do telefone entre um namorado e a secretária eletrônica da namorada é uma situação de interatividade inócua. A dita "realidade virtual" de todos os jogos eletrônicos é uma situação emblemática de interatividade inócua, pois permite que uma pessoa interaja com a simulação de uma realidade (ahistórica), sem efetivamente intervir na realidade humana (histórica). A interatividade inócua é fantasiosa e irreal, pois se trata de uma simulação. São ações inférteis, que nunca participam da elaboração do espaço, pois não interagem com objetos reais. Mas, em se tratando de uma simulação, a realidade virtual desperta uma reação sensorial semelhante àquela despertada pela realidade concreta. Basta-nos lembrar que muitos países hegemônicos na tecnologia computacional utilizam o conceito de "realidade virtual" para treinar suas forças armadas. A simulação se torna tão completa que ao se deparar com o real o indivíduo se encontra condicionado a ponto de enfrentar a situação verdadeira como se não fosse, e, assim, perde a sua sensibilidade com o objeto de sua intervenção. O mesmo ocorre em inúmeras situações da vida civil.

A interatividade real se dá através de duas facetas indissociáveis, uma física e outra fluida. O aspecto físico é caracterizado pela infra-estrutura, a conectividade. O fluido refere-se ao que é veiculada através dessa infra-estrutura, a virtualidade. O aspecto físico constitui uma esfera dos objetos técnicos, enquanto o fluido caracteriza uma esfera das ações. O aspecto físico congrega sistemas de objetos técnicos articuláveis e articulados, enquanto o fluido congrega ações catalisadas pelo uso da informação. No que se refere à Internet, optamos por associar a esfera dos objetos com tudo àquilo que viabiliza a conexão, portanto, à conectividade, enquanto a fluidez das ações proporcionada pela conectividade ficará associada ao virtual, portanto, à virtualidade. 
A conectividade e virtualidade são conceitos mutuamente reguladores, pois, de fato, trata-se da relação entre o sistema de objetos e o sistema de ações, respectivamente.

A compreensão do grau de interatividade proporcionado pela Internet apóia-se, assim, nesses dois conceitos, a conectividade e a virtualidade. 


\section{7 - Os Primórdios da Virtualidade}

A Virtualidade é sempre proporcionada pela Conectividade, e é, por esta, limitada aos recursos e localizações então disponíveis. Qualquer fluxo na rede alcança até os limites da infra-estrutura que lhe foi designada, pois o projeto dessa rede já subentende isso. Em contrapartida, a demanda pela Virtualidade gera a necessidade de implantação de novos ou renovados objetos técnicos no território, isto é, exige maior Conectividade. O volume crescente na troca de informações, bem como a previsão de demanda futura em parcelas do território exigem novas infra-estruturas, que suportem a maior densidade e extensão da rede. Assim, a necessidade de transmitir mais dados exige a expansão quantitativa e qualitativa dos objetos técnicos envolvidos na execução da comunicação. A virtualidade é um ambiente de ações virtuais, enquanto a conectividade é o conjunto dos objetos técnicos articulados e dedicados à virtualidade. Um aspecto age como norma sobre o outro. Assim como os objetos técnicos se alinhavam aos propósitos da parcela da sociedade que a rede atendia, isto é, Universidades, bases militares, governo e os "think tanks", a informação que fluía através dela, evidentemente, também correspondia com os interesses desses participantes. Nesse sentido, o propósito ideológico-estratégico da rede da ARPA tendia a manter o seu uso restrito às instituições coerentes com essa lógica.

A Arpanet, o embrião do que mais tarde se tornaria efetivamente a Internet que conhecemos hoje, era incipiente, pois os nós ainda eram poucos. Em 1969, consistia de apenas 4 nós. Em 1971, a rede atingia 15 nós, que davam acesso a 23 hosts (representam o conjunto de máquinas comutadoras ou computadores). Até 1980 , a rede aproximava-se dos 200 nós. Isso nos permite dizer que até as vésperas de seu qüinquagésimo nó, lá pelos idos de 1975, a rede era mais uma ideologia do que uma solução pragmática de curto prazo. A rede era insuficientemente complexa para ser decisiva na manutenção de um comando apropriado do território, no advento de uma guerra nuclear. Contudo, a virtualidade estava sendo bem explorada entre os diversos envolvidos da rede, desde os seus primórdios, e isso acabou por justificar a sua expansão futura. Assim, a 
virtualidade e suas possibilidades impulsionaram a criação de novos objetos técnicos, viabilizando a rede em outras porções do território.

Os cientistas e engenheiros que utilizavam diariamente a rede da ARPA foram estudando as potencialidades da comunicação virtual, de modo que a maior parte das modalidades que utilizamos na Internet de hoje foram desenvolvidas ainda nos anos de 1970. A mais popular das modalidades de comunicação da Internet, o e-mail, surgiu em 1971, como invenção de Ray Tomlinson, da BBN (Bolt, Beranek and Newman Incorporated). Conforme uma pesquisa desenvolvida pela ARPA em 1973, essa modalidade já seria responsável por $75 \%$ de todo o tráfego de informações pela sua rede. Historicamente, essa importante proporção iria se manter no futuro, apesar do progresso em outros aspectos da comunicação virtual. 


\section{8 - As Decorrências na Divisão Territorial do Trabalho}

No período Teórico-Experimental, ainda que a tecnologia de comunicação virtual tenha se concentrado em certas instâncias da sociedade estadunidense e com alguns poucos participantes estrangeiros, a divisão do trabalho sofreria mudanças consideráveis. O fluxo intensificado entre as instituições diretamente envolvidas pela rede iria pressionar aquelas não envolvidas a responderem de forma mais rápida, e condizente com esse ritmo. Ao mesmo tempo, as instituições que estavam fora da rede constituíam um "atrito" para os que já estavam envolvidos. Esse descompasso logo serviria de justificativa para que outras instituições se envolvessem com a rede da ARPA, colaborando, assim, para o aumento dos nós. O fator ideológico-estratégico de fundo se reforçaria cada vez mais.

Como produto direto do aumento dos nós, as instituições começariam a exigir, em seus quadros profissionais, pessoas com atributos até então inexistentes. $O$ mercado de trabalho estava saturado de engenheiros elétricos e eletrônicos e outros profissionais que entendiam bem de computação, na virada da década de 1960 para a de 1970. Isso se devia ao fato de que houve cortes na indústria espacial e de defesa nos EUA ${ }^{12}$. Contudo, essa disponibilidade de mão de obra não foi absorvida pela indústria informática, visto que a procura não era tão grande por componentes, mas era por gestores de informação. Buscavam-se profissionais com qualificação suficiente para gerir os fluxos de informação, ou então para fazer a manutenção dos equipamentos envolvidos nas ações de transmissão pela rede. Afora os profissionais diretamente envolvidos na manutenção e gestão dos fluxos de informação, aqueles que se dedicavam às demais profissões iriam ter que buscar qualificação para enfrentar o novo contexto da computação, que era a informática.

A informática difere da computação, pelo fato de envolver processamentos automáticos da informação, enquanto a computação envolve a automação de

\footnotetext{
${ }^{12}$ Vide o artigo do sítio:

http://www.machinedesign.com/ASP/strArticleID/14952/strSite/MDSite/viewSelectedArticle.asp
} 
processos em geral, com objetivo de simular resultados, e poupar experimentos com objetos e substâncias reais e mais caros.

Antes de se tornar um importante instrumento de comunicação de múltiplas modalidades, o computador era um instrumento a ser empregado para, somente, dar maior eficácia ao trabalho. O computador foi concebido para projetar e prever, por simulações baseadas em formulações da matemática, as possibilidades que podem ser desencadeadas a partir de um contexto inicial, mesmo que hipotético ou parcial. Em 1946, na Universidade da Pensilvânia, foi lançado o ENIAC (Eletctronic Numerical Integrator and Computer - Integrador Numérico Eletrônico e Computador), o primeiro computador eletrônico que dispunha de programação expansível e conversível (chamado de Turing completo). Em 1951 foi lançado o UNIVAC (Universal Automatic Computer I - Computador Automático Universal I), o primeiro computador comercial do mundo. Ambas não eram imaginadas como integrantes de uma rede de comunicação, pois a preocupação era o de ter capacidade de simulação. Contudo, foi somente com o advento da Informática, isto é, a necessidade de tratar a informação de forma automática que foi possível imaginar uma estrutura como a Internet.

Antes do advento da informática, o que se tinha eram peças da computação isoladas pelas empresas, servindo como instrumentos de controle, análise e de eficiência. Dava-se eficiência e eficácia às unidades isoladas, ou seja, tratava-se de uma melhoria significativa de produtividade, mas era apenas o aprimoramento do status quo. É preciso distinguir que, do ponto de vista do espaço, o advento da computação não é tão relevante, mas o da informática é essencial, pois é esta que influi e colabora para que o meio técnico-científico adquira o aspecto informacional.

Do ponto de vista prático, a instauração da informática no aparelho computador criou uma primeira perspectiva, que foi do ponto de vista da circulação. Ali que tínhamos um conjunto de aparelhos isolados, poderíamos, a partir da informática, integrar os conteúdos desses aparelhos, além de compartilhar as simulações entre as unidades integradas, e, futuramente, homogeneizar os processos e procedimentos diversos. Isso revolveria por completo as organizações e os usos 
que fazem do território. A tendência era a de que as organizações seriam muito mais bem estruturadas e homogêneas em suas unidades, fortalecendo o poder central delas. O computador estaria cumprindo, mais uma vez, a função de promover a eficácia e a eficiência, incluindo, a partir de então, esses aspectos à informação. 


\section{9 - Os Ideais da Internet}

A década de 1960 foi marcada nos EUA pela luta massiva pelos direitos de igualdade étnica, pela escalada dramática da Guerra do Vietnã (1959-1975), principalmente depois de 1964, pela Revolução Cubana (1955-1959), pelas políticas subseqüentes de intervenção nos países da América Latina e pelas tentativas de combate à pobreza urbana, em Nova York e Chicago, principalmente. Permeando esse contexto, havia o espectro recorrente da possibilidade de guerra nuclear com a União Soviética. Esse contexto da Guerra Fria conduzia a expectativas, que refletiam nas ações institucionais e individuais, principalmente nas Universidades. Uma porção dos intelectuais das instituições militares, acadêmicas e governamentais dos EUA já devia considerar outras aplicabilidades à rede, senão a militar-estratégica de sobrevida à catástrofe nuclear.

À esteira das proposições da juventude da época por trocar a guerra pela confraternização, diversos intelectuais vislumbraram a rede como um meio de promover ideais políticos, inclusive no tocante aos direitos civis e às ideologias: os e-mails e as listas de discussão seriam usados também como meios para discutir os rumos da sociedade. A Arpanet, futuramente Internet, estava começando a ser utilizada como instrumento de promoção de uma dialética universal, onde distância física deixaria de ser pretexto para a omissão. Era uma apologia às horizontalidades, contudo, restrita às paredes das instituições credenciadas. Essa característica, de promotora de uma dialética universal, permeia a mentalidade dos usuários da Internet até hoje.

Como resultado dessa mentalidade, os administradores da ARPA começariam a discutir as possibilidades de abrir a Internet para o uso civil amplo. Outros intelectuais vislumbravam a utilização comercial da rede, visto que muitos professores e consultores trabalhavam também no mundo corporativo. Nesse sentido, é compreensível que uma iniciativa de uso público da rede tenha sido lançada, em 1974, por uma companhia de alta tecnologia, a BBN (Bolt, Beranek and Newman Incorporated), chamada de Telenet. Essa rede, como é escrito na 
"Linha do Tempo da Internet" de Hobbes ${ }^{13}$, era um "clone" da Arpanet, isto é, uma cópia estrutural da Internet. A BBN desenvolveu a tecnologia de "pacotes de informação" para ser implantada na Arpanet, ainda na segunda metade da década de 1960, e empregou essa mesma tecnologia para criar a Telenet, pouco menos de dez anos depois. As potencialidades comerciais eram grandes, contudo, o desenvolvimento dessa capacidade demandaria alguns anos de pesquisa no campo da própria computação. O computador, nessa época, era um equipamento imenso e caro demais para que um indivíduo pudesse dispor em casa, a não ser que fosse milionário (milionário, nos anos de 1970 corresponde a um bilionário, em 2006). Além do custo do computador, não era difícil um aparelho ocupar todas as paredes de uma sala de uns quatro metros quadrados. $O$ comércio eletrônico seria viável e finalmente desenvolvido somente após o surgimento do microcomputador.

${ }^{13}$ Sítio mantido por Robert Hobbes Zakon: http://www.zakon.org/robert/internet/timeline/ 


\section{0 - O Fim da Exclusividade da Internet}

O desenvolvimento da Telenet (1974) abriu o precedente necessário para justificar a abertura da Internet para o uso público. O impacto dessa abertura no território estadunidense seria grande, visto que as corporações e instituições civis nãogovernamentais poderiam começar a utilizar os mesmos recursos disponíveis, até então, exclusivamente para algumas Universidades e outras instituições estratégicas, bem como para os militares.

Certamente, a estratégia de diversas instituições contava exatamente com a menor rapidez da circulação de informações para atingir certos objetivos, seja pelo ganho de tempo para decidir ou de articulação de forças ou capitais. Isso vale para qualquer setor da economia, principalmente aquelas que tiveram a implantação mais agressiva da informática, como os bancos. Graças à crescente implantação da informática, muitas estratégias institucionais tiveram que ser revistas, outras foram totalmente suplantadas, quando não as próprias instituições o foram, por não poderem bancar uma revolução tecnológica. As instituições moribundas foram sendo suprimidas por conta da inadaptabilidade às novas tecnologias implantadas no seu setor da economia. O território seria revolvido, de forma crescente, por verticalidades mais poderosas e velozes, algo que pegaria de supetão até mesmo instituições relativamente mais bem preparadas e capitalizadas.

A conseqüência direta do fim da exclusividade da Internet, com a implantação da Telenet, foi o início de um rearranjo territorial de todos os setores da economia. Isso ocorreu principalmente naqueles setores mais sedentos de informação (como é o caso dos serviços, em geral). 


\section{CAPÍTULO II - O PERÍODO DA NORMATIZAÇÃO E DA INTERNACIONALIZAÇÃO (1975-1991)}




\section{1 - A Consagração de Normas de Comunicação pela Rede}

Este período se caracteriza pelo estabelecimento dos protocolos universais de comunicação da rede, bem como pelo desenvolvimento ambicioso da microinformática, e de sua expressiva internacionalização. Os primeiros experimentos com o protocolo TCP/IP ${ }^{14}$ (em 1973, com Robert Kahn e Vinton Cerf ${ }^{15}$ ), e a busca pela criação do computador pessoal (PC - do inglês "Personal Computer") são decorrências essenciais para a compreensão do estado atual da rede, pois tratam-se do desenvolvimento das normatizações. Esse período é também caracterizado pelo uso simultaneamente militar e acadêmico da rede. Provavelmente por questões de segurança e de avanço tecnológico, isso deixou de acontecer em 1983, com a criação da MILNET, exclusivamente para uso militar. A rede passaria, então, a ser exclusivamente acadêmica.

Na década de 80 do século $X X$, vale a pena citarmos inflexões importantes, e que potencializaram a expansão e a fluidez da Internet. Essas inflexões resultaram mais de ações políticas, do que de decisões propriamente técnicas, ainda que tenham sido sobre a adoção de concepções técnicas e conseqüentes de estudos de viabilidade dessa natureza.

O ano de 1982 foi o do estabelecimento de uma padronização dos protocolos do Departamento de Defesa (DoD) dos EUA para o do TCP e IP (este vem do Inglês Internet Protocol, i.e., Protocolo de Internet, criado em 1978), hoje conhecido como protocolo TCP/IP, presente em qualquer computador de configuração comum em 2006, além da popularização do sistema operacional UNIX (BSD), versão Berkeley (Arnaldo MANDEL et alli, 1997, pgs. 28 e 29). A UCLA ${ }^{16}$ e a Noruega, no mesmo ano, adotariam os mesmos protocolos, e esse país escandinavo se integraria através da SATNET (rede que estava em teste desde 1977, baseada no uso de satélites, e com protocolo TCP/IP). O importante a

\footnotetext{
${ }^{14}$ As duas abreviações vêm do Inglês. TCP refere-se a Transmission Control Protocol, i.e., Protocolo de Controle de Transmissão, enquanto IP representa Internet Protocol, i.e., Protocolo de Internet.

${ }^{15}$ Esses dois engenheiros, Robert Kahn (ARPA), e Vinton Cerf (Universidade de Stanford), foram os criadores da Arpanet.

${ }^{16}$ UCLA = Universidade da Califórnia em Los Angeles.
} 
destacar dessa busca por padronização é que tal atitude iria potencializar a conectividade e a fluidez entre os interlocutores, diminuindo barreiras de linguagem entre máquinas, e permitindo que uma quantidade maior de pessoas passasse a dominar as operações envolvidas. Ainda em 1982, os Países Baixos, a Dinamarca, a Suécia e o Reino Unido, simultaneamente, se interligaram através da EUNET, e um serviço de correio eletrônico foi colocado à disposição de seus usuários. Compartilhemos, nesse sentido, uma citação de Ivo DIAS DE SOUSA (1997, pg. 10):

"Nos anos oitenta, muitos grupos de pessoas passaram a estabelecer ligação à Rede, o que aumentou em muito a sua utilidade", e argumenta que "a Internet é valiosa porque muitas pessoas estão ligadas a ela" (Ivo DIAS DE SOUSA, 1997, pg. 10).

Portanto, este período é notadamente caracterizado pela normatização da rede, isto é, foi um período em que surgiu a preocupação com a padronização e a conversibilidade de arquivos e outras modalidades da informação entre computadores. 


\section{2 - O Surgimento da Micro-computação}

Vale dizer que o ano de 1975 nos pareceu o mais prolífico dos anos 70 do século XX no campo da computação. Vejamos que no início desse ano, a empresa MITS $^{17}$, da cidade de Albuquerque (estado do Novo México, EUA) lança o Altair 8800 , o primeiro dos microcomputadores pessoais que, de acordo com Bill GATES (1995, pg. 29), possuía como cérebro um processador 8080 , fabricado pela então não menos incipiente empresa INTEL. Conforme a descrição de Bill GATES (1995, pgs. 25 e 29), o Altair 8800 tinha uma aparência muito diferente dos computadores pessoais modernos, pois nem possuía monitor ou teclado, tinha o tamanho aproximado de uma torradeira de pão (Bill GATES, 1995, pg. 29), e tampouco foi criado com intuito de competir com os grandes computadores comerciais, que naquela época ocupavam, no mínimo, o espaço de uma estante de livros. Contudo, a raiz de toda essa evolução que hoje testemunhamos não estava posta no fato de haver microprocessadores à disposição, pois o primeiro havia sido criado ainda em 1972, o 8008 da INTEL (Bill GATES, 1995, pg. 25). O que realmente fez do microprocessador uma alavanca foi o modo pelo qual a indústria passaria a enxergar o papel desses dispositivos, algo que determinaria a tendência futura da computação e também da informática. Nesse sentido, e como desdobramento imediato do lançamento do Altair 8800, na mesma cidade sede da MITS, dois jovens empreendedores, Paul Allen e William Gates (Bill Gates) fundariam antes do final de 1975, a primeira empresa de programas (software) voltados somente para microprocessadores, a Microsoft (Bill GATES, 1995, pgs. 29 a 31). Essa empresa objetivava, em médio prazo, catalisar uma popularização dos microprocessadores, explorando as possibilidades de processar funções matemáticas mais complexas, o que aumentaria a aplicabilidade desses no cotidiano da sociedade. Além desse objetivo, a Microsoft buscou também uma padronização no sistema operacional e a difusão dessa necessidade de convergir rumo a um padrão universal. Isso permitiria que máquinas de configurações

\footnotetext{
${ }^{17}$ A MITS (Micro Instrumentation and Telemetry Systems), foi fundada em 1968 por Forrest Mims e Ed Roberts. Até 1972, a empresa estava dedicada à indústria de calculadoras.
} 
diversas pudessem trabalhar com os mesmos padrões de instrução, o que foi de suma importância para o desenvolvimento e difusão da rede da ARPA, já que conectividade depende de uma padronização mínima entre máquinas. Em abril de 1976, foi lançado o Apple I, desenvolvido por Steven Wozniak e pelo empreendedorismo de Steve Jobs. Diferente de todos os outros equipamentos portáteis de então, que eram baseados no chip 8080 da INTEL, o Apple I foi baseado no chip MOStek 6502. Desenvolveu-se, portanto, uma arquitetura alternativa à da INTEL, que duraria até hoje.

Tão fundamental quanto explanarmos a primeira estratégia da INTEL/Microsoft e da Apple/Macintosh, é preciso falar sobre a capacidade tecnológica que permitiu aumentar, de forma exponencial, o poderio dos microprocessadores com base no silício no decorrer das décadas finais do século $X X$ e da primeira década do século XXI. Isso potencializou as possibilidades de instruir um aparelho para executar funções matemáticas sempre mais complexas, e com velocidade cada vez maior. Outra evolução paralela importante foi a crescente miniaturização dos componentes e circuitos eletrônicos, que permitiria a introdução dos microcomputadores em residências e escritórios, já no fim da década de 1980. A importância das tecnologias de informação, baseada no crescente desenvolvimento dos microprocessadores, atingiu um patamar que se tornou notório nos corredores do poder: em 1976, o primeiro chefe de estado manda, oficialmente, uma mensagem de correio eletrônico - a Rainha Elizabete II, do Reino Unido.

O desenvolvimento de equipamentos, linguagens de programação e de outros recursos, além do aperfeiçoamento na concepção de protocolos de comunicação, promoveu a expansão da Arpanet, como se pôde perceber nesses primeiros anos de sua implantação. A maior parte das bases da atual Internet foi lançada antes mesmo do fim da década de 70 do século XX. Ainda que o aperfeiçoamento dessas bases continuasse, a Arpanet estava, no início dos anos 80, partindo para uma fase de expansão física de seu alcance e infra-estrutura.

Curiosamente, o surgimento do microcomputador nos pareceu um resultado de movimentos horizontais, pois advinha de um raciocínio de democratização dos 
recursos da computação, tendo em vista o maior acesso à informática, ainda que com finalidade lucrativa a médio e longo prazo. Afinal, ainda que Bill Gates e Steve Jobs sonhassem com a fortuna proveniente de seus empreendimentos, ninguém poderia realmente prever ou acreditar na revolução das décadas seguintes em termos de gerenciamento e distribuição de informação. Por não se tratarem de atores hegemônicos deste período, a Microsoft, a INTEL e a Apple surgiram a partir de horizontalidades, pequenas solidariedades técnicas. Nessa época, a gigantesca empresa IBM era quem ditava os rumos da indústria da computação mundial com as suas máquinas do tamanho de armários. Muitos dos aficionados pela micro-computação lançaram empreendimentos semelhantes aos de Bill Gates, mas, em boa parte, sem o mesmo sucesso. O final do período se caracterizou pela conversão destas empresas na indústria poderosa que conhecemos em 2006. Diversos atores hegemônicos preexistentes a essa revolução passaram a se interessar pela tecnologia que estava sendo engendrada (a exemplo da própria IBM). Podemos dizer que a microinformática nasceu de horizontalidades e tornou-se uma criadora de verticalidades no futuro, enquanto a rede da ARPA, e, por conseguinte, a Internet, nasceu de verticalidades, que futuramente passaria a despertar e reforçar horizontalidades. 


\section{3 - A MILNET, e a gradativa passagem para o predomínio civil da Rede: Implicações na divisão territorial do trabalho}

Os acadêmicos e os militares iriam se separar até o final desse período, visto que a percepção de utilidade da Internet tornava-se cada vez mais diferente entre esses dois segmentos da sociedade. Os acadêmicos estadunidenses sempre estiveram associados a empresas, dado o senso comum de aliança entre Universidade e empresariado nos Estados Unidos. Seria, portanto, natural buscar trazer as potencialidades da Internet para o plano empresarial. Enquanto isso, os militares enxergavam o potencial estratégico da rede, moldado na justificativa inicial de criação da Internet, que era o de permitir ao Estado sobreviver a situações extremas de conflito e viabilizar a logística militar pelo vasto território dos Estados Unidos e, veladamente, além dele. Criou-se um contexto de ruptura. A liberalização da tecnologia de Internet de sua função restrita a órgãos estratégicos (com a Telenet, em 1974) pavimentou o caminho rumo à comercialização da própria Arpanet. Ao mesmo tempo, com a difusão amplificada da técnica pela sociedade, inicia-se uma capilarização da rede, e as sociedades locais passariam logo a utilizá-la em movimentos horizontais. A capilarização somente foi possível com os adventos da micro-computação e da microinformática (os dois em 1975).

O ano de 1983 foi caracterizado pela separação das funções civis e científicas das militares da Arpanet (Ivo DIAS DE SOUSA, 1997, pg.10). Foi criada a MILNET, a rede de interlocução estritamente militar, inicialmente com cerca de $60 \%$ dos pontos de rede da Arpanet original nos EUA (68 dos 113 pontos existentes naquele país). Essa rede exclusivamente militar separava-se do restante da Arpanet por meio de alguns poucos gateways (portais controlados por senhas e outros recursos de segurança), que são os seus pontos exclusivos de acesso. Ainda em 1983, são lançadas as primeiras estações de trabalho de mesa (desktops) sob plataforma operacional UNIX, que incluíam um programa de interação em rede de padrão IP. Lançam-se as bases, portanto, da normatização 
para a Internet (vide item 2 deste capítulo), com vistas ao sistema operacional (meio de interação) e de protocolos de comunicação (modo de interação).

Em 1981 e 1982, com o apoio entusiástico da ARPA e da Fundação Nacional de Ciência ("National Science Foundation", ou NSF), que é o correlato estadunidense do $\mathrm{CNPq}^{18}$, foi possível concretizar a idéia de Lawrence Landweber (da Universidade de Wisconsin, EUA), que era a de interligar todos os departamentos de Ciências da Computação dos EUA através da rede CSNET (Arnaldo MANDEL et alli, 1997, pg. 27).

Para Arnaldo MANDEL et alli (1997, pg. 28), "o conjunto da rede da ARPA e da CSnet constituiu-se na primeira rede heterogênea e pode ser considerado 0 precursor da Internet".

Após 1983, diversas mudanças estruturais e técnicas foram implantadas, de modo a comportar a rápida expansão da Internet, além da exigência de conexões mais rápidas nesse meio. O ano de 1984 (conforme o "Hobbes Internet Timeline") foi marcado pela implantação do Sistema de Nomes de Domínio (do Inglês "Domain Name System"), conhecido pela sigla DNS, que permitiria o desenvolvimento dos nomes únicos para sítios de Internet tal como os conhecemos hoje. É importante ressaltar que nesse ano foi criada a Cisco Systems, empresa cuja missão até hoje é "a fabricação de elementos ativos para a rede Internet, isto é, computadores especializados que tratam do encaminhamento, pela rede, dos pacotes digitais" (Arnaldo MANDEL et alli, 1997, pg. 29). O surgimento da Cisco Systems permitiu a diminuição de custos de tais equipamentos, o que colaborou em muito na expansão (em termos de velocidade e capacidade) da Arpanet (Arnaldo MANDEL et alli, 1997, pg. 29).

A divisão territorial do trabalho, neste período, sofreria um grande impacto depois do biênio 1974-1975. A experiência bem sucedida com a criação da Telenet e os adventos da micro-computação e da microinformática foram convincentes, e pavimentaram o caminho para a passagem da Internet para o domínio público, bem como se criou a expectativa de grande expansão dessa rede, dada a possibilidade de efetivar uma capilaridade, realizando, assim, um dos preceitos

\footnotetext{
${ }^{18}$ Conselho Nacional de Pesquisa, do Brasil.
} 
iniciais da concepção da grande Rede. De forma mais agressiva que no período anterior, as empresas adotavam o computador, contudo, com a finalidade de empregar a informática como instrumento de concorrência ${ }^{19}$, padronização e comunicação entre unidades da mesma instituição ou cadeia produtiva e/ou organizacional. O período anterior empregava o computador apenas como máquina de cálculos complexos e de previsão. Nesse sentido, podemos afirmar que as verticalidades são ainda mais numerosas e variadas em comparação com o período anterior.

Desde então, nos EUA, a profissão de datilógrafo estava se tornando obsoleta, enquanto ser programador significava garantia de emprego pelos anos seguintes. A modalidade de comunicação Telex entraria em crise, pelo abandono crescente do sistema por parte das grandes instituições financeiras e industriais. O fluxo de capitais pelo território passava a se dar em minutos, não mais no decorrer de horas. Os profissionais executivos, acostumados a terem tempo de decidir procedimentos e processos passaram a contar com a tecnologia para auxiliá-los pesadamente, pois apenas o olho humano não percebia com a mesma facilidade de outrora a complexidade dos movimentos dos capitais. O conteúdo técnicocientífico crescente do espaço permite que a informação, tal qual ocorre com diversos outros produtos, seja produzida em quantidades maiores, em tempo cada vez mais reduzido e em áreas menores (parafraseando Milton SANTOS, 1994, pg. 127). Como enfrentar essa mudança tão complexa?

Surgem, nesse contexto, estruturas para atenderem as necessidades organizacionais, as intranets e as extranets.

\footnotetext{
${ }^{19}$ A velocidade com que a instituição responde a estímulos momentâneos do mercado, a agilidade na mudança de processos por conta de defeitos, falhas ou decisões de ordem estratégica.
} 


\section{4 - Intranets e Extranets}

Do ponto de vista mais geral, a Intranet consiste de uma rede privada, separada por firewalls (protocolos, i.e., barreiras de segurança) do restante da Internet, através de gateways, ou até mesmo fisicamente separada da Internet, constituindo uma rede paralela. Portanto, uma intranet pode ou não usufruir da infra-estrutura da Internet, contanto que utilize da mesma tecnologia (protocolos) da grande rede mundial. O objetivo central de uma intranet é o de dar fluidez às informações entre as unidades de uma organização qualquer, e que podem estar dispersas ou não pelo território, ou até dispersas por territórios diversos. Uma intranet interliga as partes de uma mesma organização, independentemente da distância ou das barreiras culturais e idiomáticas que as separem.

Uma extranet é consistida de um grupo restrito de organizações interligadas através de uma rede privada, seja ela integrada ou não à Internet. As extranets podem congregar organizações ou indivíduos como usuários autorizados em torno de uma mesma intranet, bem como podem congregar duas ou mais intranets entre si. A extranet é o grupo de usuários autorizados a interagir com uma intranet, contudo, não integrante da organização proprietária desta intranet. As extranets, tampouco, estão restritas a circunscrições territoriais, da mesma forma das intranets.

A Internet abriga, seguramente, em sua imensa estrutura, grande parte das intranets e extranets existentes no mundo, embora estas estejam separadas por protocolos de segurança do restante dos usuários. Vejamos, a seguir, alguns pontos de vista:

Organizações corporativas (Business-to-business, ou B2B): A intranet permite o fluxo de dados e de instruções entre as equipes e setores de forma rápida e com baixo custo, de modo a influenciar a produtividade da empresa. A extranet, por sua vez, congrega clientes empresariais, fornecedores e outros parceiros essenciais, permitindo eficácia à cadeia produtiva e eficiência no atendimento entre as partes envolvidas no processo. Nesta classe, vale citar o sistema 
bancário e financeiro, bem como empresas em consórcio para trabalhar em projetos comuns.

Organizações sociais ou solidariedades: Uma intranet permite o fluxo de dados e informações de maneira a permitir que se atinjam graus de mobilização rápidos em torno da realização dos objetivos e solução de conflitos. A intranet, nesse caso, permite o desenvolvimento de discussões dos rumos do movimento e com participação ampla. A extranet permite que articuladores externos a essas organizações usufruam de acesso privilegiado, geralmente com base no alinhamento coerente de interesses. Nesta classe, vale citar os movimentos sociais diversos existentes, e que utilizam a Internet para atender seus objetivos. Aqui também vale ressaltar os partidos políticos e os movimentos terroristas.

Organizações em portais de serviços (Business-to-consumer, ou B2C): Possui uma intranet voltada, exclusivamente, para o atendimento dos participantes da extranet, isto é, presta serviços voltados para usuários que não possuem outro vínculo senão o de cliente de um serviço prestado pela organização em meio virtual. Nesta classe, vale citar os provedores gratuitos ou pagos de e-mail, bem como as imobiliárias eletrônicas, shoppings e lojas virtuais. 


\section{5 - Noções da Economia Cognitiva}

Os preceitos históricos do comércio entendem que todos os objetos existentes podem ser interpretados como mercadoria. Sejam sapatos, cadeiras, comidas, bebidas e até mesmo animais e pessoas, todos são comercializáveis. O advento do primeiro salário pago no mundo desdobrou na interpretação da força de trabalho como um objeto. A informação também foi transformada em "coisa", isto é, algo comercializável, e com muito mais intensidade no decorrer do século XX. Com a transformação do meio técnico-científico em um meio também informacional ${ }^{20}$, a informação deixou de ser um acessório de objetos, e passou também a ser encarado, por si mesmo, como objeto (Thierry GAUDIN, 1999) ${ }^{21}$.

A venda de uma informação não se encerra apenas com a transação, mas, em tese, seria pela renúncia voluntária de seu uso, ou então do seu esquecimento, por parte do primeiro dono. Uma renúncia ou esquecimento realmente não acontecem. A informação não é um bem palpável, não é um objeto, portanto, não é algo que se passe, simplesmente, de um dono para outro. Em verdade, a venda da informação geralmente é conformada com o fato de que o comprador continua sendo dono da informação, enquanto o vendedor passa a ser um segundo dono, que pode compartilhar com o primeiro dono a informação ${ }^{22}$. Quando há um termo de compromisso entre as partes, a informação não deverá ser repassada para terceiros, sem que haja comum acordo entre os donos atuais. Diferente dos objetos, a informação jamais é vendida como tal. Sempre ela será partilhada no

${ }^{20}$ Conforme Thierry GAUDIN (1999, pg. 27): “...depois dos anos (19)80, o sistema técnico mundial inicia uma transição, do sistema industrial para o sistema cognitivo...".

${ }^{21}$ Convergindo em linhas gerais com Pierre Lévy, o autor descreve que os objetos são o diagrama dos projetos humanos (o prato para o comer, o jarro para o beber etc.), e a prescrição destes diagramas é o que chama de "logiciel". Gaudin faz uma descrição detalhada das origens dos logiciels.

22 Conforme Thierry GAUDIN (1999, pg. 39): “...na sociedade cognitiva, a propriedade muda de natureza. Se te dou um quilo de açúcar, eu me separo definitivamente dele. Não é mais meu. Se eu te dou uma informação, nós dois partilhamos a mesma informação. Ela se torna um bem comum". 
ato, isto é, torna-se um bem comum às partes, ainda que os direitos de seu repasse são reservados ao novo "dono".

Tentemos elaborar uma pequena tipologia do tratamento com a informação, tendo em vista uma percepção nossa. A informação pode ser um privilégio ou um catalisador.

Como privilégio, o raciocínio é que o primeiro a obter a informação, deve segurá-la como monopólio o maior tempo possível, explorando-a em detrimento daqueles que poderiam se interessar também pela posse. A informação só passa a ser vendida se houver uma imposição legal e ética ao dono do monopólio. O preço da informação privilegiada geralmente será muito alta, proporcional à sua importância. Geralmente, a informação enquanto privilégio tem a ver com segredos industriais ${ }^{23}$, patentes, direitos autorais, grupos concorrentes etc.

O raciocínio já é diferente quando a informação é um catalisador. A informação catalisadora deve ser disseminada o quanto antes, pois o que esta desencadeará na sociedade, seja no setor econômico ou político é o que realmente interessa para quem a detém ${ }^{24}$. O preço da informação é moderado, pois se visa um acesso amplo. No geral, a informação catalisadora tem a ver com ideologias, costumes, imprensa, procedimentos de segurança, produtos da informática, pirataria em geral etc.

Podemos dizer que a consagração do protocolo de Internet, TCP/IP, é exatamente um caso de informação catalisadora, enquanto o desenvolvimento do primeiro microprocessador estava calçado em informações privilegiadas.

\footnotetext{
23 "A economia cognitiva considera que o essencial não é compreender as transformações da matéria realizadas pela indústria - isto é apenas um resultado -, mas as causas imateriais, que se exprimem principalmente pelos processos de reconhecimento que se encontram na sociedade. No fundo, a produção é apenas um subproduto" Thierry GAUDIN (1999, pg. 53).

${ }^{24}$ A ação da informação "se faz sentir em todos os níveis e constitui o principal sustentáculo da difusão de novos modelos de consumo inspirados nos países mais ricos" (Milton SANTOS, 2004, pg. 36 - Obra original de 1975).
} 
O período da normatização e da internacionalização coincide com a transição do sistema técnico mundial, descrita por Thierry GAUDIN (1999), em que deixa de ser industrial e passa a ser cognitiva ${ }^{25}$.

Thierry GAUDIN (1999) contesta o papel hoje exercido pela economia enquanto avaliadora dos fluxos materiais da produção. Há, contudo, uma economia cognitiva por trás disso, que consiste nos fluxos imateriais (a informação), que determinam os destinos da produção. A economia, tal qual se propõe, acaba em um reducionismo contábil, e não analisa a essência, a causalidade do que determina o fluxo material.

25 “...depois dos anos (19)80, o sistema técnico mundial inicia uma transição, do sistema industrial para o sistema cognitivo..." (Thierry GAUDIN, 1999, pg. 27). 


\section{6 - O Efeito-Demonstração}

A computação, e, posteriormente a informática, jamais teriam tido sucesso se não fosse pelo efeito-demonstração. Vejamos que o período Técnico-Experimental foi exatamente o de uma extensa demonstração das potencialidades do computador enquanto aparelho de comunicação. Foram feitos experimentos, testes, instalaram-se objetos técnicos no território e implantaram-se parâmetros técnicos que permitiriam a eficácia na comunicação. Tudo isso foi uma seqüência de demonstrações. Cada demonstração exerceu fascínio nos potenciais usuários, e estes, oportunamente, adquiriram o equipamento necessário ou os conceitos fundamentais para implantar sistemas compatíveis em suas instituições.

O período da normatização e da internacionalização foi caracterizado pela demonstração da eficácia de certos protocolos de comunicação, sendo o TCP/IP o consagrado pela Internet, e pelo pesado efeito-demonstração exercido pelo gerenciamento e comunicação eletrônicos de informações em muitos países. A internacionalização da Internet se deu graças ao fascínio exercido pelas potencialidades da informática, primeiramente para as aplicações acadêmicas, isto é, no processamento de simulações complexas, que simplificam os procedimentos de experimentação. Penetrado no âmbito universitário, as técnicas associadas à computação e à informática foram analisadas por acadêmicos que também eram cidadãos e consumidores. Não custava associar procedimentos computacionais com o próprio cotidiano. O ambiente acadêmico foi aquele em que o efeitodemonstração teve seu maior desempenho.

O objeto computador tornou-se, na linguagem corrente, um sinônimo de vanguarda, modernidade, futuro. O discurso em torno do computador é o de que ser dono de um aparelho sofisticado é estar, de maneira inevitável, associado ao futuro. Ocorre que, seguramente, a grande maioria dos usuários de computador não explora mais de uma ínfima porção das potencialidades desse aparelho, que se obsoletizam em meses. A maioria das pessoas que possuem computadores em casa utiliza processadores de textos e de planilhas, acessam a Internet e brincam com os jogos eletrônicos. Mas, de todo esse conjunto de aplicações, as 
potencialidades do microprocessador são colocadas à prova apenas nos jogos eletrônicos. São raras as aplicações caseiras que exigem desempenho desafiante ao computador, afora os jogos eletrônicos. Um caso seriam o dos prestadores de serviços em informática, que desenvolvem programações avançadas e muitas vezes ensaiam seus passos em seus computadores pessoais. 


\section{7 - Super-estradas da Informação e Aldeia Global}

O ex-vice-presidente dos EUA, Albert Gore (no mandato do presidente William Jefferson Clinton, 1993-2001) é o principal colaborador político que influiu na estruturação da Internet, desde 1976. Ao ocupar uma cadeira na câmara de deputados, lançou um projeto visando criar uma "rodovia de dados" (data highway). Em 1986, "Al" Gore patrocinou politicamente e, portanto, lançou as bases para o "Estudo de Rede de Supercomputadores", que, entre outras coisas, fez um levantamento das demandas públicas gerais pela Internet, e projetou uma rede de supercomputadores para servir à sociedade, através das universidades estadunidenses. Em 1991, Al Gore escreveu um artigo para o periódico "Scientific American", intitulado "Uma Infra-estrutura para a Aldeia Global ${ }^{26 " ~(A n ~}$ Infrastructure for the Global Village), em que vislumbra a Internet como meio de comunicação de massa. Em 1993, já como vice-presidente dos EUA, Al Gore lança o programa "Infra-estrutura Nacional de Informação" (National Information Infrastructure), mais conhecido pelo apelido dado pela administração Clinton de "Super-estrada da Informação" (Information Superhighway). Essencialmente, à parte das frases de efeito, foi necessário ter agentes políticos, não apenas técnicos altamente qualificados, para que a Internet pudesse expandir e chegar ao estado em que a conhecemos hoje. Era preciso dispor da tecnologia e implantar normas que possibilitassem a sua aplicação na sociedade e no território nacional. O papel de Al Gore, na sociedade estadunidense foi exatamente o de viabilizar a votação de normas que permitissem a expansão da Internet pelos Estados Unidos, indiretamente, servindo como efeito-demonstração para o resto do mundo. A noção de uma "rodovia de dados", ou uma "Super-estrada da Informação", é uma associação que foi resgatada dos tempos da expansão rodoviária no território dos Estados Unidos, nos anos de 1930. Isso não ocorreu por acaso, visto que tanto as rodovias como a Internet visam à circulação: uma de veículos automotores que transportam cargas, e a outra a veiculação rápida de informação.

\footnotetext{
${ }^{26}$ O termo "Aldeia Global" foi cunhado por Wyndham Lewis, em seu livro "América e o Homem Cósmico", de 1948. Posteriormente, o sociólogo Marshall McLuhan tornou a expressão bastante famosa através de suas obras.
} 
A idéia central dos projetos de Al Gore e de outros políticos que simpatizavam com as tecnologias envolvidas na Internet era a de efetivamente fazer com que através destas a economia dos EUA pudesse ser movimentada.

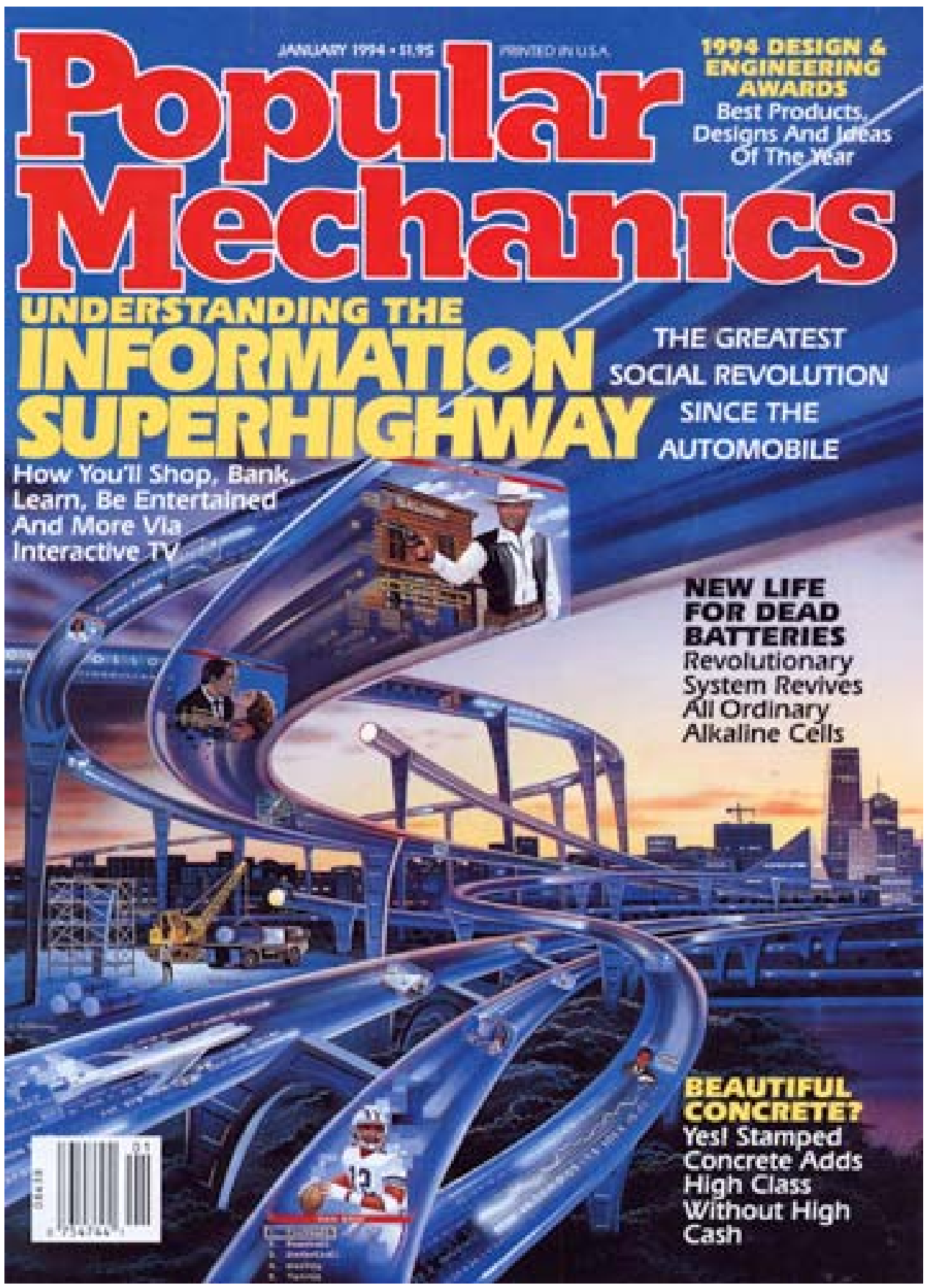

FIGURA 3 - UMA CAPA DE REVISTA DE 1994, COM A PRINCIPAL REPORTAGEM FAZENDO UMA APOLOGIA DAS DIVERSAS FACILIDADES QUE A INSTAURAÇÃO DE UMA SUPERESTRADA DE INFORMAÇÃO PODE TRAZER. CRIA INCLUSIVE UM PARALELO COM A REVOLUÇÃO DA AUTOMOBILÍSTICA. 
Os termos "Super-estrada da Informação" e "Aldeia Global" renderam vastas discussões, na mídia e na academia, no decorrer da década de 1990, por trazerem consigo alguma polêmica. Uma diz respeito à analogia da circulação de informações com as estradas de veículos automotores, enquanto a outra discute um suposto "encolhimento" do planeta, por conta da rapidez e da facilidade com que se podem exercer as ações à distância.

A super-estrada possui duas definições relevantes que pudemos verificar no dicionário do idioma Inglês Oxford: "uma rota ou rede para a transferência de informação em alta velocidade" e "uma rede nacional de fibras-óticas proposta para os Estados Unidos". A super-estrada, portanto, seria o conjunto de artérias informacionais que percorrem os Estados Unidos, e que está sendo copiado por diversos países do mundo ainda hoje.

Na década de 1990, graças às super-estradas de informação, pôde-se começar a resgatar a percepção de uma "aldeia global". A analogia é a de que a redução das distâncias para se comunicar foi tão grande que a impressão que fica é a de que se vive em uma aldeia, onde todos falam com a mesma facilidade com todos.

O que podemos aproveitar dessas duas consagradas expressões da mídia e do discurso político é que as super-estradas de informação corresponde a uma das infra-estruturas necessárias para se viabilizar a Internet, isto é, trata-se de um aspecto da conectividade. Enquanto isso, o "efeito" de aldeia global, isto é, a impressão de que a distância foi sobrepujada pela técnica é a virtualidade resultante da existência das super-estradas e de outros acessórios da Internet. 


\section{8 - A Planetarização da Conectividade}

Ainda que outros países possuíssem redes próprias, isoladas da rede gerenciada pela ARPA, como era o caso da França (CYCLADES), só poderíamos interpretar como "Internet" a rede tal qual foi concebida no padrão TCP/IP. Isso se deve ao fato de que há todo um conjunto de protocolos técnicos de comunicação que prevaleceram na Internet moderna, e que descendem diretamente da estrutura original da Arpanet, mesmo que tenha havido algumas colaborações estrangeiras. Outra característica essencial é que mesmo havendo redes já internacionais como a USENET, a BITNET e a FIDONET, nenhuma delas dispunha dos mesmos recursos tecnológicos da Arpanet, inclusive no que se refere à infra-estrutura de comunicação. Contudo, tais redes serviram para introduzir, aos países participantes delas (inclusive o Brasil, na BITNET desde 1988) a cultura de utilização de redes computacionais de comunicação e interação, à semelhança da Arpanet. As bases de uma internacionalização da Arpanet foram lançadas pelo surgimento das redes parciais na Europa e no Japão. Essas verticalidades que precipitavam sobre as sociedades desses países serviram de catalisador de novas necessidades, a do computador e da Internet. Ao mesmo tempo, horizontalidades também foram despertadas nessas sociedades, e usufruiriam da técnica para tal.

Com intuito de simplificar a linguagem, e tentarmos ser mais objetivos, consideremos que o termo "conectividade" refira-se à infra-estrutura da Arpanet ou idêntica a ela (as que utilizam o protocolo TCP/IP), e não se aplica a toda rede indistintamente ${ }^{27}$. A conectividade expandiu-se graças ao uso de estações de captação de sinais de satélites (SATNET), estações de rádio (PRNET) e cabos de fibra-ótica (ARPANET, propriamente dita) ${ }^{28}$.

A conectividade é intensificada pelo aumento quantitativo e qualitativo dos equipamentos (objetos técnicos) fixados ao território. Quanto maior o numero e tipologia, maiores as possibilidades de conexão.

\footnotetext{
${ }^{27}$ Em verdade, o termo "conectividade" é aplicável a todas as infra-estruturas em rede, seja a Arpanet, a USENET, ou às redes de telefonia fixa ou celular. Contudo, o nosso escopo é a Arpanet, e quando citarmos "conectividade" é referente àquela específica dessa rede, em específico.

${ }^{28} \mathrm{http}: / /$ www.nap.edu/readingroom/books/newpath/chap2.html
} 
A intensificação da conectividade é acompanhada de outros dois movimentos: o de adensamento e o de capilarização da rede. O adensamento envolve o reforço das ligações de rede já existentes, de modo que possa comportar fluxos maiores naqueles trechos de maior demanda (é um movimento seletivo). Além disso, o adensamento traz consigo a possibilidade de instaurar uma nova geração tecnológica de cabos, terminais e satélites, o que pode permitir maior velocidade aos fluxos que passam por ali (isto também é seletivo). A capilarização é a expansão dos pontos possíveis de interatividade humana através da rede, isto é, o aumento de computadores ligados à rede.

Foi iniciado o processo de internacionalização da conectividade a partir de 1973 , com a entrada da Noruega e do Reino Unido, por meio de satélites de comunicação. Em 1978, o Canadá, a Austrália e Hong Kong integraram-se aos EUA através de uma rede distribuída, que somente mais adiante incorporou o protocolo TCP/IP na sua estruturação.

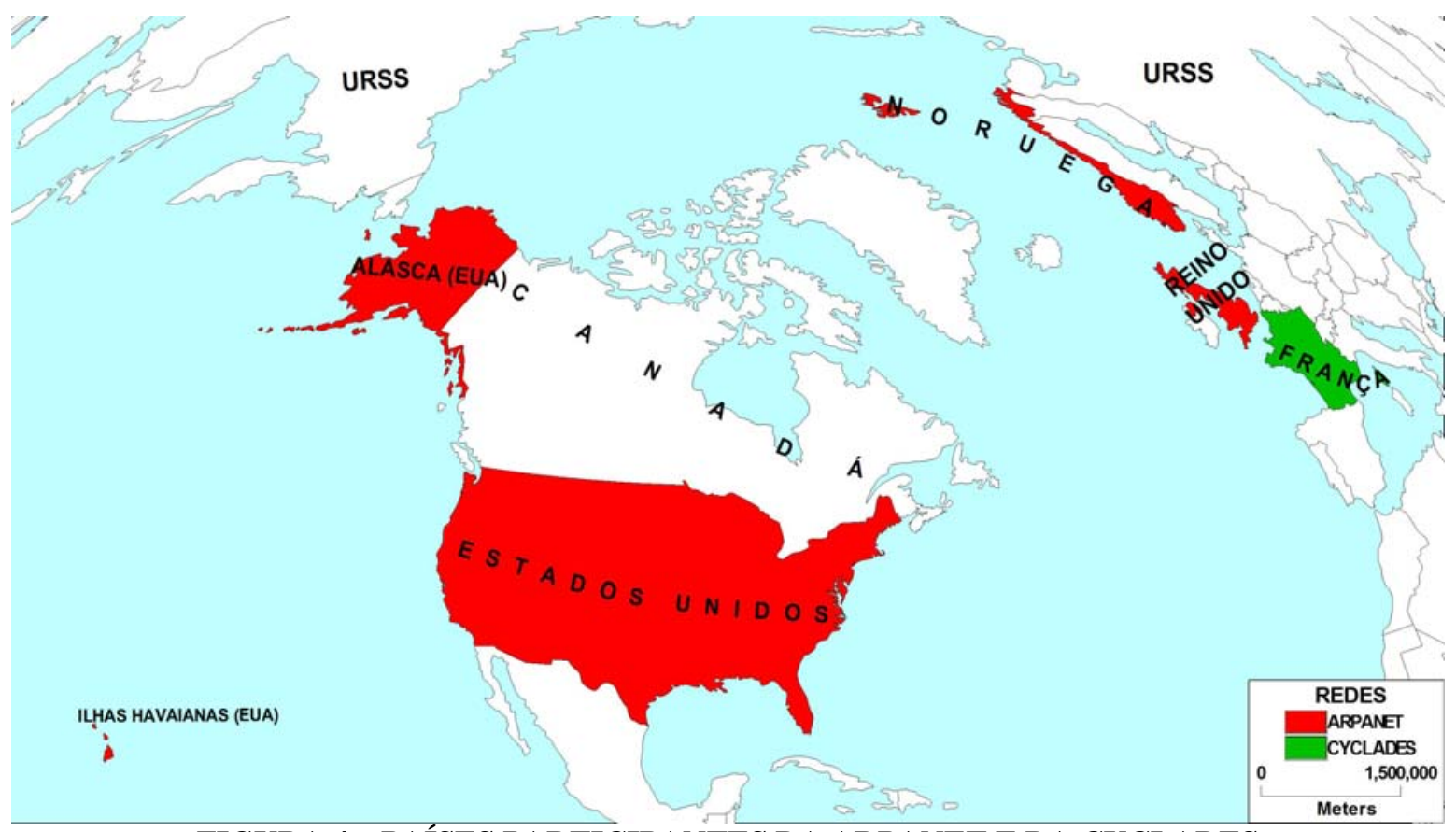

FIGURA 4 - PAÍSES PARTICIPANTES DA ARPANET E DA CYCLADES

A Arpanet, poderia finalmente ser pensada como uma primeira geração de uma "Internet", já que passava a articular outras redes à sua estrutura e entrava numa fase de internacionalização. Diversas instituições acadêmicas estadunidenses já estavam em contato com os estabelecimentos europeus e canadenses, o que 
inspirava a idealização de uma rede universalista, que permitisse trocas de informação acadêmica. Os militares prosseguiram com a MILNET (1983), então a Arpanet passou a ser totalmente de domínio civil, mas ainda, predominantemente, acadêmico. Outros países, tendo em vista uma futura conexão planetária, já investiam na infra-estrutura necessária.

Em 01/01/1983, a Fundação Nacional de Ciência dos EUA ("National Science Foundation" ou NSF), lançou uma rede com base exatamente no mesmo protocolo da Arpanet, o TCP/IP, juntamente com um programa robusto de financiamento de supercomputadores, que seriam espalhados por diversas Universidades estadunidenses $^{29}$. Isso resultou na criação da NSFNet, a segunda geração da Internet, que em 1985 foi liberada para exploração comercial. A NSFNet, futuramente, absorveria toda a estrutura da Arpanet, entre outras importantes redes, transformando-se na Internet que conhecemos hoje.

A Linha do Tempo de Hobbes nos ensinou que em 1986 a NSF lançou cinco novos centros de articulação de servidores, todos dedicados para o uso da sua grande rede. A iniciativa foi tomada por conta de certo grau de saturação da rede, devido ao grande interesse de segmentos da sociedade estadunidense (Arnaldo MANDEL, 1997, pg. 29). Constituiu-se, com esses novos investimentos, uma nova "espinha dorsal" (do Inglês "backbone"), com a conexão mais rápida da época (1986), equivalente às atuais placas de MODEM de 56 Kbps (conforme a Linha do Tempo de Hobbes) ${ }^{30}$. Interessante notar que tais placas, em 1986, eram utilizadas para levar uma fluidez pioneira à Internet, e, já ao final dos anos 1990, essas mesmas estavam sendo amplamente utilizadas em computadores caseiros, e facilmente vendidas em qualquer loja de peças para computadores em São Paulo. Com os avanços no campo dos protocolos de comunicação e da eficácia dos equipamentos contidos nessas "espinhas dorsais" da rede, permitiu-se que o número de nós quintuplicasse entre outubro de 1984 e novembro de 1986. A rede quintuplicou novamente com os novos centros, mas no intervalo de apenas um

\footnotetext{
${ }^{29}$ Vide: http://www.nsf.gov/about/history/nsf0050/internet/launch.htm e http://en.wikipedia.org/wiki/Internet.

${ }^{30}$ Observe-se que essas placas entraram em desuso ao final da década de 1990, visto que surgiram novas técnicas de conexão à rede, como os modems a cabo e os transmissores a rádio.
} 
ano, atingindo mais de 28.000 nós em dezembro de 1987 (Linha do Tempo de Hobbes, 2004).

Os anos de 1987 e 1988 se caracterizaram pelos primórdios da privatização da rede, pela sua internacionalização acentuada e pelo aumento significativo de velocidade. A NSF fechou acordo de gerenciamento de sua "espinha dorsal" com a Merit Network Incorporated, com envolvimento da IBM (International Business Machines), em 1987. A NSF, em 1988, já contando com os serviços da Cisco Systems (Arnaldo MANDEL, 1997, pg. 29), expandiu a velocidade do equipamento da NSFNet para o nível T1, isto é, 1,544 Mbps, o que equivale dizer a quase 27,6 vezes a velocidade máxima de 1986 (conforme a Linha do Tempo de Hobbes). A essa altura da evolução das redes informacionais, a NSFNet já agregava para si parte dos propósitos da CSNET (esta se fundiria à BITNET primeiro) e da antiga estrutura da Arpanet (já separada da MILNET desde 1983), e vinha interligando as outras redes existentes como se fossem seus subsistemas, a cada nova expansão. Um exemplo disso é a incorporação da ampla FIDONET (1988). A expansão e as características de outras redes, ainda que ligassem dois ou mais países há mais tempo ${ }^{31}$, não poderia ser considerada como "Internet", pois não carregavam consigo, entre outras características técnicas, a normatização que foi consagrada internacionalmente e que perdura até os dias de hoje (2006), o padrão TCP/IP.

Até 1989, a quantidade de redes existentes pelo mundo contabilizava 105 (em citação feita por Arnaldo MANDEL et alli, 1997, pg. 29), dentre as quais estava a BITNET, que chegou ao Brasil em 1988 através do CNPq, e, apenas três meses depois, se comunicaria também através da FAPESP (Arnaldo MANDEL et alli, 1997, pg. 31). O protocolo da BITNET não era o TCP/IP da NSFNet (tido já como universal, o padrão consagrado para a grande rede), o que significava que o Brasil ainda estava fora da Internet. Contudo, o Brasil já se encontrava em uma articulação interessante, através de uma das redes mais essenciais para pesquisadores no mundo. A FAPESP levaria à cabo o financiamento da

\footnotetext{
${ }^{31}$ A Alemanha e a China já se correspondiam, via correio eletrônico, desde 20/09/1987, através de uma rede de protocolo CSNET, o que diferenciava dos preceitos consagrados da NSFNet (TCP/IP).
} 
conectividade entre as três universidades estaduais paulistas, através da ANSP (Academic Network at São Paulo) como piloto inicial (Arnaldo MANDEL et alli, 1997, pg. 31). Através da FAPESP, o Brasil também se articulou às redes HEPNET, DECNET e USENET, o que fez com que o CNPq se caracterizasse como pioneiro, e a FAPESP como difusor das redes no país e de sua cultura (Arnaldo MANDEL et alli, 1997, pg. 31).

O ano de 1990 foi caracterizado pelo fim da Arpanet, totalmente absorvida pela estrutura da NSFNet, e também por um marco importante: o surgimento do primeiro provedor comercial de Internet do mundo (Conforme a Linha do Tempo de Hobbes), chamado sugestivamente "The World" (O Mundo). Esse ano encerrase com 28 países $^{32}$ articulados à NSFNet (Internet), dentre os quais o Brasil, que em fevereiro de 1991 faria sua primeira ligação no protocolo TCP/IP (Arnaldo MANDEL et alli, 1997, pg. 31).

O desenvolvimento dos sistemas operacionais orientados a objetos (uso de ícones e outros recursos gráficos ao invés de linhas de comando de programação) permitiu impulsionar a utilização de computadores por pessoas que não fôssem ligadas ao ramo da análise de sistemas e áreas intimamente afins. Isso permitiu grande capilarização no bojo das primeiras sociedades a receberem os impactos do desenvolvimento da microinformática. Mas, uma outra conseqüência muito importante foi decorrente desse desenvolvimento. A informática permite a aceleração na execução de diversas atividades por si só, mas a simplificação dos comandos operacionais das máquinas desencadeou as possibilidades de seu uso em quase todas as indústrias e por pessoas de diversos tipos de instrução. Assim, um empregado poderia exercer seu trabalho com a eficácia de outros dois ou três, e, além disso, superar a sua própria eficiência em termos produtivos. A existência de uma rede mundial permitiu o surgimento de empresas de produção territorialmente segmentada, portanto, deu maior liberdade de escolha aos

\footnotetext{
${ }^{32}$ Alemanha, Argentina, Austrália, Áustria, Bélgica, Brasil, Canadá, Chile, Coréia do Sul, Dinamarca, Espanha, Finlândia, França, Grécia, Índia, Irlanda, Islândia, Israel, Itália, Japão, México, Noruega, Nova Zelândia, Países Baixos, Protetorado de Porto Rico, Reino Unido, Suécia e Suíça (Linha do Tempo de Hobbes).
} 
conglomerados multinacionais e levou, entre outras conseqüências, ao enfraquecimento dos sindicatos de ação local.

Em novembro de 1990, os laboratórios da CERN (Suíça) lançaram a WWW, isto é, a World Wide Web (Rede Ampla Mundial), possuidora de características específicas que a diferenciam do restante da NSFNet. Há quem provavelmente considere a Internet como tal após a criação da WWW, portanto, sob a ótica específica da configuração tecnológica envolvida no processo de condução e organização dos dados. Contudo, para os propósitos deste estudo, até a criação da WWW, a NSFNet era a primeira geração tecnológica da Internet, pois é a técnica e o seu conceito (incluindo-se a sua normatização) que realmente nos interessa.

A NSFNet, como segunda geração de Internet, efetivamente foi a que se internacionalizou de maneira rápida e consistente, entre os anos de 1987 e 1991. Contudo, a internacionalização se deu de forma seletiva. Vejamos o porquê, na figura a seguir:

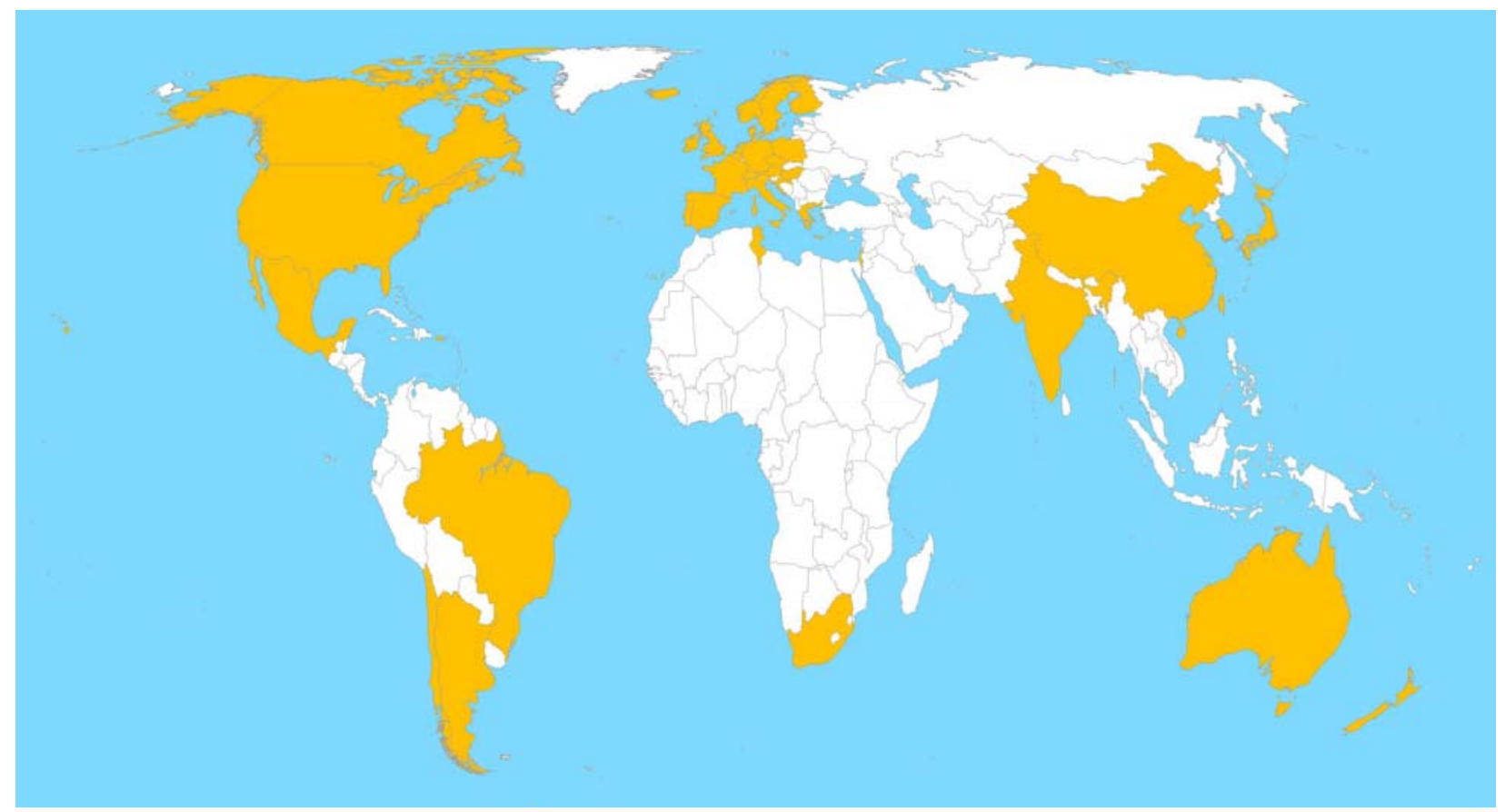

FIGURA 5 - PAÍSES PARTICIPANTES DA INTERNET EM 1991 
Entre 1988 e 1991, todos os países centrais do ocidente foram se conectando à Internet, e mais o Japão, a China, a Índia, a África do Sul, Israel e a Coréia do Sul. A Tunísia e a Nova Zelândia já participavam, embora não fossem poderosos. A única exceção dentre os países mais poderosos do Planeta que não participava da grande rede era a Comunidade de Estados Independentes, que vinha da crise econômica e social do então recente colapso da União Soviética. Em questão de 22 anos, a conectividade, que se projetava sobre menos de $5 \%$ da superfície terrestre (apenas alguns estados dos EUA em 1969), passava a projetar-se sobre $50,0 \%{ }^{33}$. A conectividade já estava autorizada, portanto, em metade da superfície terrestre. Contudo, e salvo exceções, tratam-se da porção que é ocupada pelas maiores potências militares e econômicas do Planeta.

Façamos uma analogia grosseira com o conjunto indissociável de ações e os objetos, ensinado pelo saudoso professor Milton SANTOS (1996), em sua obra "A Natureza do Espaço". Imaginemos que cada Estado-nação do mundo corresponda a um objeto integrante de um sistema (o sistema internacional). O conjunto dos Estados-objetos possui uma hierarquia, uma tipologia que vai dos mais modestos aos hegemônicos. Cada Estado-objeto autoriza, resiste ou sucumbe às ações, devido às características individuais de cada ação e de cada unidade desse sistema (de objetos). Concentremo-nos em apenas um subconjunto de todo o espectro de ações possíveis entre esses Estados-objetos: o conjunto das ações que diz respeito à seqüência dos movimentos humanos associativos (políticos, acadêmicos e técnicos) necessários para a implantação da conectividade. Como pressuposto, entendamos também que os investimentos ${ }^{34}$ dos Estados-nação em prol da conectividade constituam um "grau" de autorização dessas ações. Nesse sentido, podemos compreender que os Estados-objetos hegemônicos do contexto final da década de 1980 autorizaram a conectividade, juntamente com alguns poucos Estados-objetos mais modestos (a exemplo da Tunísia e da Nova Zelândia) em detrimento de muitos outros Estados-objetos, que por motivos

\footnotetext{
${ }^{33}$ Do total de terras emersas do Planeta, o território dos EUA ocupa menos de 8,5\%. O conjunto dos países retratados em laranja na figura 3 ocupa precisamente $50 \%$ da superfície terrestre do total de $114.904 .340 \mathrm{~km}^{2}$ do Planeta.

${ }^{34}$ Independentemente da origem dessas verbas, se são de impostos ou de empréstimos externos.
} 
diversos não alocaram verbas para esse propósito (fatores políticos, culturais ou econômicos). O conjunto das motivações culturais, ideológicas (desde a política até a tecnologia), ou de competição comuns a esses Estados-objetos pesou na autorização das ações de implantação da conectividade. Em contrapartida, os demais Estados-objetos, por falta dessas mesmas motivações não ingressaram nessa primeira "onda" de conectividade (entre 1987 e 1991). 


\section{9 - A Mundialização da Virtualidade}

A conectividade constitui uma possibilidade para a virtualidade, assim como esta cria a demanda por maior conectividade. A conectividade é planetarizada, por ser uma expansão física, material, de equipamentos, todos presos às leis da física. A virtualidade se mundializa, pois, trata-se do limite das ações humanas, transcendentes das leis da física. A capacidade de transpor atitudes mais complexas de um lugar para outro sem que haja o deslocamento do agente é uma virtualidade. O artifício amplifica as possibilidades de uma ação, bem como viabiliza a difusão de novas ações. Um exemplo é o dos médicos que já experimentaram conduzir cirurgias à distância através de mecanismos diversos de conectividade associados (braços robôs, computadores avançados etc.), isso já na década de 1990. Há uma simultaneidade, como se os braços do cirurgião se estendessem pela distância necessária para efetuar a operação. A virtualidade, meio exclusivo da Internet35, permite, pela primeira vez, que se aja direta e amplamente na história de outro local sem que tenha havido um deslocamento físico do agente. A virtualidade, portanto, depende da conectividade. A ação é emitida através de um pulso no momento do desejo pessoal do agente, com as falhas e as virtudes de quem está fisicamente presente. Contudo, o desfecho dessa ação (um evento) encontra-se condicionado aos recursos de conectividade disponíveis. Nesse sentido, a disponibilidade de conectividade para a metade da superfície terrestre pressupõe que a virtualidade seja possível somente nessa porção. Não há virtualidade sem uma permissão territorial para isso, que é a conectividade.

${ }^{35}$ A realidade virtual dos jogos não é para nós uma virtualidade, é uma simulação inócua. 


\section{CAPÍTULO III - O PERÍODO COMERCIAL E DAS ASSIMILAÇÕES (APÓS 1991)}




\section{1 - Sistema de Comunicação, de Transporte ou uma Entidade Sincrética?}

Havia um razoável incômodo na hipótese de aceitarmos a Internet diretamente como um sistema equivalente ao dos transportes, já que ela não conduz objetos palpáveis. No entanto, a Internet permite a aceleração e a amplificação de ações, bem como viabiliza novos vetores de ações. A grande rede aumenta a probabilidade das ações e dos objetos se relacionarem. Isso parece caracterizar um sistema de comunicação.

Ainda que a Internet deva grande parte de sua viabilidade aos avanços da tecnologia telefônica, a grande rede se distingue também dos demais sistemas de comunicação pelo grau de interatividade que ela proporciona, de forma crescente, aos interlocutores. Até o advento da Internet aberta ao público, a interatividade era ainda mais incompleta.

Vale ressaltar que consideramos o grau de interatividade como a intensidade com que se realiza a reciprocidade entre os interlocutores através de um mecanismo de comunicação.

O telefone permite a conversa, e todas as suas implicações. Contudo, quem nunca fingiu alegria ao atender uma pessoa com quem não queríamos conversar, só por questão de educação? O rádio é um eficiente comunicador, mas a interação fica por conta de outro meio complementar, como o telefone. Ademais, é um meio de mão única. A televisão, por sua vez, permite que uma pessoa visualize e ouça outra, mas, também não passa de um meio de mão única: quem, por puro desabafo, jamais se indignou diante do aparelho e proferiu a ele injúrias ou gestos? Certamente, o apresentador de televisão sequer tomou conhecimento disso. A televisão também necessita de outros meios para torná-la efetivamente interativa. A concepção de um programa de televisão interativo alia a imagem e o som do aparelho com o telefone, e mais recentemente à Internet. Veja-se que os limites de interatividade de um sistema de comunicação, em geral, são ultrapassados com o emprego de sistemas complementares. Com a Internet, essa regra não se aplica, principalmente após os avanços dos anos 1990. A 
interatividade proporcionada pela Internet parece suprir a causa dos três sistemas que citamos anteriormente, e a grande versatilidade dela permite que se vislumbre a possibilidade futura de interagir quase com a mesma eficácia da presença física. Mas, afinal, será que a Internet terá que ser considerada como uma entidade "sincrética", ou "híbrida"? É um sistema de comunicações que, por conta de sua capacidade de projeção virtual dos indivíduos, está adquirindo aspectos da circulação convencional?

Elaboramos um questionário36 e entrevistamos um diminuto universo de vinte e cinco pessoas. Entre outras perguntas, elaboramos uma que indagava sobre a possibilidade de considerarmos a Internet um meio de circulação além de ser de comunicação. De todos os entrevistados, $68 \%$ (ou 17 pessoas) responderam que a Internet "jamais substituirá os automóveis, ônibus e trens, pois não é um meio de circulação, apenas de comunicação". Outros $16 \%$ (ou quatro pessoas) acreditam que a Internet "será um meio complementar aos meios de circulação existentes (automóveis, trens etc.), contudo, corre em paralelo aos problemas de trânsito das grandes cidades e de muitas injustiças sociais, ainda que resolva problemas pessoais e profissionais com eficácia". Isto significa que, no melhor das hipóteses, há uma percepção de que a Internet é um complemento pouco influente na circulação. Ainda assim, 36\% dos entrevistados (nove pessoas) crêem estar suficientemente poupadas de se deslocarem pessoalmente para os lugares, pois utilizam modalidades de comunicação em grande parte de seus cotidianos.

O que podemos concluir a respeito do questionário é que há apenas uma tendência em crer que a Internet é uma entidade "sincrética" ou "híbrida", visto que existe uma percepção pouco representativa da questão do deslocamento para resolução de problemas pessoais diversos. Talvez o universo amostral tenha sido pequeno demais para nosso intento, ou ainda tenha faltado uma opção mais precisa em nosso questionário, que pudesse investir mais no assunto.

\footnotetext{
${ }^{36}$ Vide o anexo desta dissertação.
} 


\section{2 - A Internet Comercial}

A partição da Arpanet que se tornou exclusivamente acadêmica permitiu uma revolução tecnológica sem precedentes até então. Pavimentou-se o caminho para a implantação das práticas comerciais e o desenvolvimento do conceito que hoje conhecemos como Internet. O uso comercial é hoje um dos traços fundamentais da grande rede informacional. A internacionalização, a normatização e a capilarização das técnicas que viabilizam a Internet pelas sociedades recebeu grande impulso, o que daria crescentes justificativas ao seu uso cotidiano e banalizado pelo mundo. Estamos ressaltando exatamente o fato de que 0 desenvolvimento das técnicas associadas à Internet atendeu os preceitos de um meio técnico-científico-informacional, desde seus primórdios. Pode-se arriscar a afirmação de que a Internet é inerente ao desenvolvimento e manutenção do meio técnico-científico-informacional. Vejamos alguns fatos a respeito disso.

A exuberância no crescimento do uso da rede chamou a atenção do capital financeiro e comercial, em verdade, dos ex-acadêmicos que exerciam atividades em estabelecimentos fora das universidades. É notório e comum aos acadêmicos estadunidenses trabalhar em conjunto com o capital industrial e corporativo. Em 1990, surgiu o primeiro provedor comercial de Internet no mundo, "The World", inaugurando uma nova era do uso da rede.

A Internacionalização da rede se acelerou nesse período, e a rede se expandiu em termos de infra-estrutura e de demanda em ritmo fantástico. Não demorou muito para que se buscasse realizar as mais diversas operações financeiras e comerciais pela Internet, e o uso civil comum superar o acadêmico. Essa época se caracterizou pelo surgimento dos sistemas operacionais orientados a objeto (MacOs e Windows) ${ }^{37}$, que simplificou o uso dos microcomputadores e impulsionou a venda desses aparelhos para usuários leigos à programação. Nessa época surgem as primeiras especulações a respeito do "efeito casulo". A indústria da informática, desde os componentes até os programas se tornou um

${ }^{37}$ Sistemas operacionais orientados a objeto são aqueles que adotaram a semiologia como solução para a simplificação das extensas linhas de comando que eram necessários digitar antigamente. 
negócio de grande sucesso e rentabilidade, algo tido como certeiro, de infinitas possibilidades e de expansão (aparentemente) ilimitada. Em 1994 a Internet chegava ao Brasil. Surgem as empresas virtuais, às vezes formadas por duas ou três pessoas e seus computadores, e que operavam pelo mundo. Muitas empresas vingaram, tornando-se grandes e poderosas, permitindo que, posteriormente, se tornassem físicas, como a livraria Amazon e, para citar um caso brasileiro, o sítio Submarino. O chamado Vale do Silício era tema recorrente de programas especiais da CNN e de reportagens nas principais revistas de negócios. Não raras eram as vezes em que propagandas de sítios de Internet como a Tantofaz, iG, MercadoLivre, Yahoo!, Super11, Cidade Internet e a Lokau apareciam na televisão brasileira, muitas vezes patrocinando programas em horário nobre. A revolução foi irresponsável a ponto de gerar uma especulação desenfreada, que desembocou na crise da bolsa NASDAQ, em 2000. Muitas empresas foram infladas em valor por especuladores mais agressivos, engendrando uma verdadeira série de implosões no Vale do Silício e em outras partes do mundo. Fomos testemunhas oculares de um período de decadência da FENASOFT no Brasil e de mudanças profundas no quadro das lojas da região da Santa Ifigênia, na cidade de São Paulo.

A indústria da informática chegou a uma fase mais realista, após a crise do NASDAQ, em que se concluiu que não há exatamente uma "nova economia", mas simplesmente a velha economia de sempre, com os percalços e atritos que 0 mundo físico proporciona. A fluidez acelera, mas não emancipa o fluxo de capitais do espaço, mundo afora. A fluidez não emancipa, tampouco, os capitais do contexto histórico em andamento. Os ataques à Nova York e a Washington, nos Estados Unidos, em setembro de 2001, apenas confirmam que a virtualidade é apenas um artifício, uma prótese que supera, mas não suprime a existência de um meio físico e sequer ultrapassa a realidade política e cultural entre sociedades e dentro delas. Esse período parece fundir-se ao ressurgimento de alguns princípios típicos do período anterior, como a relação interpessoal e com base em referências, bem como as páginas de opinião pessoal. A partir de 2003, passou-se a notar uma forte expansão dos weblogs (também chamados de "blogs"). Os blogs 
são sítios de opinião pessoal do seu próprio administrador, uma moda surgida a partir de meados dos anos 1990, mas pouco ressaltada pela mídia e até então pouco prestigiada pelos usuários mais leigos (hoje é a maioria). Em 2003 surge também o fenômeno Orkut, que inaugura uma faceta de solidariedade neste período.

Os laços de solidariedade através dos weblogs passam a se reforçar entre pessoas. Há ponderações de que os sítios dessa natureza servem mais para coletar informações pessoais do que para incrementar a solidariedade. Seja como for, isto irá requerer estudos mais aprofundados a respeito do uso ilícito desses sítios. Talvez um trabalho no âmbito do Direito. Ainda assim, os laços estão se incrementando pelo mundo através de sítios de opinião pessoal e os de estilo do Orkut. Os usuários do Brasil despontaram como fortes participantes no Orkut logo em seu começo, e hoje constituem mais de $60 \%$ de seus usuários.

O comércio eletrônico parece ter atingido patamares superiores aos que antecederam a crise do NASDAQ, mas sem a euforia do período precedente. 


\section{3 - O Desempenho das Nações na Internet}

Haveria um meio de podermos avaliar o grau de poder que os países exercem no meio virtual? Existem diversos índices que avaliam o poder dos países em determinados quesitos do mundo virtual, como é o caso daqueles criados pela União Internacional de Telecomunicações (International Telecommunications Union - ITU). A ITU criou o DAI (Digital Access Index - Índice de Acesso Digital) e o DOI (Digital Opportunity Index - Índice de Oportunidade Digital), ambos objetivando ressaltar a acessibilidade geral dos indivíduos às tecnologias da informação. Vejamos uma breve apresentação de alguns índices:

Índice de Acesso Digital (DAl): É construído a partir do cruzamento de quatro importantes fatores, que, de acordo com seus criadores, são determinantes para o acesso às tecnologias de informação. São estes a infra-estrutura (conectividade telefônica, celular e fixa), a qualidade (disponibilidade de banda larga), os conhecimentos gerais (alfabetização e escolaridade) e o custo (das ligações). Quatro dos oito indicadores que compõem o índice envolvem diretamente a Internet: Participação da tarifa de Internet na renda nacional bruta, Banda larga internacional por cem habitantes, Assinantes de banda larga por cem habitantes e Usuários de Internet por cem habitantes. O resultado desse cruzamento, assim, causaria impacto direto no uso das tecnologias de informação. Parte-se de um ponto de vista predominantemente das próprias técnicas de informação, e em menor escala, do educacional e econômico. Em última análise, a força efetiva das nações é medida pelo grau de acessibilidade à Internet, e em menor escala, à telefonia fixa e móvel. De acordo com a ITU (2003), esse índice é calculado para 181 países. O Brasil aparece em $65^{\circ}$ lugar $(0.50)^{38}$, e o índice é liderado por três países escandinavos, nesta ordem: a Suécia (0.85), a Dinamarca (0.83) e a Islândia (0.82). Quanto mais próximo de 1.00, maior o acesso digital, logo, podemos falar em maior fluidez da informação. Na América Latina, o Chile consta com o maior índice $\left(0.58,43^{\circ}\right.$ lugar), seguido pelo Uruguai $\left(0.54,51^{\circ}\right.$ lugar) e pela

\footnotetext{
${ }^{38} \mathrm{O}$ Brasil figura em $6^{\circ}$ lugar, considerando apenas a América Latina, e $9^{\circ}$ se considerarmos os países caribenhos no cômputo.
} 
Argentina (0.53, $54^{\circ}$ lugar). Os Estados Unidos figuram em $11^{\circ}$ lugar (0.78), e o Japão em $15^{\circ}(0.75)$.

Modelo de "Info-estados" (Infostate) ${ }^{39}$ : É um modelo exclusivamente voltado para avaliar o contexto da exclusão digital, através do aspecto da economia informacional, ou cognitiva. É um índice desenvolvido pelo Secretariado Internacional da Orbicom (Canadá), uma rede de consultores diretamente associada à UNESCO. O info-estado é a síntese de dois fatores ${ }^{40}$ : consumo das tecnologias digitais, envolvendo bens ${ }^{41}$ e serviços $^{42}$ (Info-uso) com a vertente produtiva (capital e trabalho), isto é, infra-estrutura e capacitação ${ }^{43}$ (Infodensidade). Grosso modo, podemos associar a noção de fluxos com o Info-uso, enquanto a Info-densidade tem a ver com os fixos. A Info-densidade tem a ver com objetos técnicos retransmissores de dados e o seu operacional (capacitação e infra-estrutura das redes), enquanto o Info-uso tem a ver com as ações que partem ou atingem esses objetos técnicos de interação. De acordo com a Orbicom (George SCIADAS, 2003, IV), o Info-estado é medido para 139 países. Desde 2000, a Dinamarca e a Suécia se alternam com os maiores índices de info-estado, e, em 2003 apresentam-se, respectivamente, com 254.9 e 251.1. O Brasil aparece desde 1995, quando o índice foi calculado pela primeira vez, abaixo da média mundial. Em 2003 o info-estado do Brasil foi de 107.3, nota-se que é menos da metade dos dois primeiros colocados no índice. No contexto da América Latina, o Chile (127.7), o Uruguai (118.3) e a Argentina (115.0) ocupam os primeiros três lugares, seguidos pelo Brasil (107.3) e pela Costa Rica (104.3). O info-estado do primeiro colocado da América Latina, o Chile, é praticamente a metade do da Dinamarca (George SCIADAS, 2003, pg. 30). Os Estados Unidos eram o primeiro colocado neste índice em 1995 (117.1), e em 2003 ficaram em sétimo (231.8). Essencialmente, aquilo que chamamos de "lacuna digital" é a diferença entre os info-estados entre dois países qualquer.

\footnotetext{
${ }^{39} \mathrm{http} / / /$ www.orbicom.ca/media/projets/ddi2005/index_ict_opp.pdf

${ }^{40}$ Trata-se da raiz quadrada do produto entre o info-uso e info-densidade.

${ }^{41}$ Televisores, computadores, aparelhos telefônicos celulares ou fixos etc.

${ }^{42}$ Em verdade, é a intensidade com que se usam os serviços. Por exemplo, de todos os usuários de Internet, a porção que utiliza de banda larga é a de maior intensidade no uso.

${ }^{43}$ A capacitação tem a ver com os alfabetizados e a escolaridade.
} 
Índice de Oportunidade Digital (DOI): Consiste de uma tentativa de trazer a noção de info-estado para compor um índice melhor que o DAI. De acordo com o sítio da ITU ${ }^{44}$, é o único índice que utiliza parâmetros acordados unanimemente entre as nações membros da instituição. O DOI assenta-se sobre um tripé de categorias: Oportunidade, Infra-estrutura e Utilização. Cada categoria tem subitens: Uso e qualidade (Utilização), Rede e aparelhos (Infra-estrutura, que pode ser fixa ou móvel) e Custo e cobertura (Oportunidade). Há uma ligeira semelhança com o DAI, contudo, embute novas variáveis, como vimos há pouco. O mais notável desse índice é que em 2005 os primeiros lugares não ficam com os países escandinavos, como nos índices anteriormente apresentados, mas com países do Extremo Oriente: A Coréia do Sul (0.76), Hong Kong (0.67) e o Japão (0.66) ocupam os três primeiros postos. O Brasil fica em $34^{\circ}$ lugar (0.27), e em $5^{\circ}$ entre os países latino-americanos. O Chile $\left(0.43,25^{\circ}\right.$ lugar $)$, a Argentina $\left(0.39,26^{\circ}\right.$ lugar), o México $\left(0.35,27^{\circ}\right.$ lugar) e a Venezuela $\left(0.30,33^{\circ}\right.$ lugar) são os quatro primeiros da América Latina. Os Estados Unidos figuram em $13^{\circ}$ lugar no ranking mundial (0.60). Em termos de oportunidade digital, o Brasil tem menos da metade da Coréia do Sul, e praticamente a metade que é oferecida pelos Estados Unidos.

Índice de Prontidão de Rede (NRI, de Network Readiness Index): Desenvolvido pelo Fórum Econômico Mundial, é composto por três variáveis: Ambiente, Prontidão e Uso. O Ambiente é extraído a partir de três índices, com base no mercado, na regulação e na infra-estrutura. A Prontidão é calculada a partir dos graus individual, governamental e dos negócios. O Uso considera também os graus individual, governamental e dos negócios. O objetivo deste índice é o de avaliar a "propensão que cada país tem no aproveitamento das oportunidades oferecidas pelas tecnologias de informação e de comunicação" (FORBES.COM, 2005). Em setembro de 2005 a revista Forbes digital ${ }^{45}$ divulgou o ranking do NRI, e pudemos constatar diversas diferenças com relação aos demais índices. Ainda que quatro dos seis primeiros colocados no índice são países escandinavos ${ }^{46}$, 0 primeiro lugar é da Cingapura, e o quinto lugar é dos Estados Unidos. Em 2003-

\footnotetext{
${ }^{44}$ http://www.itu.int/osg/spu/statistics/DOl/index.phtml

${ }^{45} \mathrm{http}: / /$ www.forbes.com/technology/2005/03/09/cx_0309wefranking.html

${ }^{46}$ Islândia em $2^{\circ}$, Finlândia em $3^{\circ}$, Dinamarca em $4^{\circ}$ e Suécia em $6^{\circ}$.
} 
2004, o primeiro lugar era dos Estados Unidos, enquanto o segundo era de

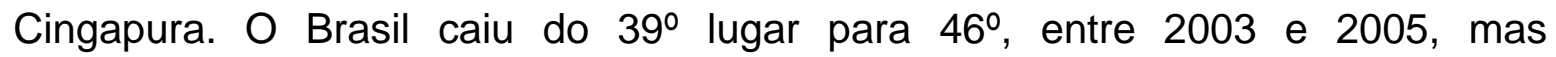
permaneceu em segundo lugar na América Latina, atrás do Chile (que caiu de $32^{\circ}$ para $35^{\circ}$ entre 2003 e 2005). O México é o próximo país latino-americano a aparecer na lista (de $44^{\circ}$ para $60^{\circ}$, entre 2003-2005), seguido pela Costa Rica (de $49^{\circ}$ para $61^{\circ}$, entre $\left.2003-2005\right)$.

Índice da Sociedade da Informação (ISI, de Information Society Index): Conforme o sítio da IDC ${ }^{47}$, a ISI analisa a habilidade de 53 países estudados "no acesso e na absorção de informação e das tecnologias de informação" (IDC, 2005). A ISI assenta-se em quinze parâmetros, distribuídos por quatro agregações: Social, Telecomunicações, Internet e Computação/Informática ${ }^{48}$. Estando todos estes parâmetros em situação favorável, a sociedade poderá ser qualificada como "Informacional Avançada" ${ }^{49}$. À frente de todos os países estudados em 2003/2004, fica a Dinamarca, seguida pela Suécia e pelos Estados Unidos. O Brasil figura em $38^{\circ}$ lugar, ficando em $3^{\circ}$ na América Latina, atrás do Chile $\left(29^{\circ}\right)$ e da Argentina ( $\left.37^{\circ}\right)$.

\footnotetext{
${ }^{47}$ IDC = International Data Corporation, dedicado a estudos voltados para a tecnologia de informação. Sítio: http://www.idc.com/groups/isi/main.html

${ }^{48}$ Social: educação secundária e superior, liberdades civis e corrupção do governo;

Telecomunicações: residências com banda larga, inscritos em tecnologia sem-fio e importações de aparelhos; Internet: total de usuários, total gasto com o comércio eletrônico, usuários residenciais e usuários móveis; Computação/Informática: computadores por domicílio, gastos totais e em serviços relacionados à tecnologia de informação e gastos com programas.

${ }^{49} \mathrm{http}: / / \mathrm{www} . \mathrm{idc} . \mathrm{com} / \mathrm{groups} / \mathrm{isi} / \mathrm{DOCS} /$ factsheets.pdf
} 


\section{4 - Por um Índice de Poder das Nações na Internet}

Depois de verificarmos os índices mencionados no item anterior, resolvemos arriscar e desenvolvermos, em um exercício, o nosso próprio índice, visando efetivamente ressaltar o poder das nações, nem tanto o grau de envolvimento das sociedades com as tecnologias de informação em geral. Nosso objetivo, inclusive, seria o de destacar o poder com relação à virtualidade, isto é, especificamente à Internet.

Para esse empreendimento, resgatamos um livro do já centenário general brasileiro Carlos Meira Mattos, com intitulado "Geopolítica e Trópicos" (1984), onde este autor resgata uma fórmula desenvolvida por Ray Steiner Cline, então diretor do Centro de Estudos Estratégicos e Internacionais da Universidade de Georgetown, em Washington (EUA). Esse intelectual foi conselheiro dos presidentes estadunidenses Lyndon Johnson (1963 a 1969) e Richard Nixon (1969 a 1974), e foi diretor de inteligência na CIA (Central Intelligence Agency) no período 1962-1966. A partir de sua experiência pessoal, Ray Cline propôs uma fórmula que tenta quantificar o poder dos Estados, pelo chamado "poder perceptível".

$\mathrm{Na}$ fórmula, encontram-se dois fatores que a fundamentam, os fisiológicos do poder - população, território, economia e capacidade militar; e os abstratos do poder - concepção estratégica e vontade nacional. De acordo com o General MEIRA MATTOS (1984, pg. 142) os fatores físicos e abstratos do poder propostos por Ray Cline realmente são "determinantes do sucesso de qualquer empreendimento político, administrativo ou militar". O General Meira MATTOS (1984, pg. 143), acrescenta a esta fórmula mais uma variável, o poder de persuadir que ele designa a letra $\mathrm{P}$, ficando a fórmula com a seguinte apresentação:

$$
P p=(C+E+M) \times(S+W+P), \text { onde: }
$$




$$
\begin{aligned}
& \text { Pp = Poder perceptível } \\
& C=\text { Massa Crítica (População + Território) } \\
& E=\text { Capacidade Econômica } \\
& M=\text { Capacidade Militar } \\
& S=\text { Concepção Estratégica } \\
& W=\text { Vontade de realizar a estratégia nacional } \\
& P=\text { Persuasão }
\end{aligned}
$$

Efetivamente, trata-se de uma fórmula em que não nos preocupamos com as fontes numéricas utilizadas em seu cálculo, mas sim com uma correlação possível com as variáveis que envolvem o nosso próprio estudo.

Após diversos ensaios, conseguimos nos satisfazer com algumas variáveis que nos permitiu exercitar algumas analogias com a fórmula de Ray Cline, já modificada pelo General Meira Mattos, a saber:

Massa Crítica: Usuários de Internet no País multiplicando o número de equipamentos conectados à Internet (hosts);

Capacidade Econômica: Usuários de Internet no País multiplicado pelo PIB per capita normalizado pela paridade do poder aquisitivo (US\$), multiplicado pelo índice de Expectativa Máxima de Vida relativa a 110 anos;

Capacidade Militar 1 (para nós, seria a "fluidez"): Numero de Telefones Fixos e Móveis por 10000 habitantes;

Capacidade Militar 2 (outro fator de "fluidez"): Numero de equipamentos conectados à Internet (hosts);

Concepção Estratégica: Usuários de Internet por mil habitantes do país;

Vontade de Realizar a Estratégia Nacional: Quantidade de Computadores por mil habitantes;

Persuasão 1: Índice de Alfabetização;

Persuasão 2: Numero médio de horas navegadas por mês;

A síntese da fórmula, após fazermos todas as adaptações, é a seguinte: 


\section{$P p=(C+E+F 1+F 2) \times(S+W+P 1+P 2)$}

Todas as variáveis descritas anteriormente integrarão a fórmula após serem normalizadas pelo logaritmo na base 10. Decidimos por isto, pois os números variam de magnitude. Da fórmula original, não se preserva a divisão em fatores fisiológicos e fatores abstratos, mas houve uma preocupação com a manutenção de analogia entre a variável original e a substituta, que nos atende. A massa crítica agrega pessoas e equipamentos envolvidos, isto é, a conectividade bruta. A capacidade econômica congrega dois fatores que envolvem qualidade de vida, isto é, o poder aquisitivo e a expectativa de vida média. Trata-se de duas variáveis que pesam muito no desenvolvimento econômico do país. Foi necessário desdobrar a "capacidade militar" em duas partes, que convencionaremos chamar de fluidez. A fluidez demonstra o quanto a população é íntima da telefonia e da própria Internet, isto é, qual a probabilidade de exposição da população às tecnologias da informação. A concepção estratégica avalia qual a parcela da população que efetivamente integra-se na rede, isto é, representa a estratégia do país através do conjunto de ações e interesses pessoais. A vontade só pode ser realizada pela disponibilidade de computadores prontos para servir de interface entre os indivíduos e a rede. A persuasão teve que ser dissociada em duas partes também, só que por um simples motivo: a indecisão de qual indicador efetivamente representaria um fator persuasivo na estratégia. $O$ índice de alfabetização indica o percentual "estocado" de pessoas que são potenciais usuários da rede: antes de saber de informática, é preciso saber ler e escrever. 0 numero médio de horas navegadas pelos indivíduos em um país expressa o peso que a informática representa em sua sociedade. É um fator de persuasão grande. Por fim, nossa fórmula do poder perceptível precisou de um nome. Sugerimos que seja o Índice de Poder Perceptivo do Meio Técnico-Científico-Informacional.

O índice aqui desenvolvido foi calculado para 204 países, e apresentamos, à seguir, os seus resultados: 
Tabela 1 - ÍNDICE DO PODER PERCEPTÍVEL NO MEIO TÉCNICO-CIENTÍFICOINFORMACIONAL

\begin{tabular}{|c|c|c|}
\hline $\mathrm{N}^{0}$ & Mundo & Índice \\
\hline 1 & Estados Unidos & 352,78 \\
\hline 2 & Japão & 347,83 \\
\hline 3 & Reino Unido (e dependências do Canal) & 335,22 \\
\hline 4 & Alemanha & 333,63 \\
\hline 5 & Canadá & 332,66 \\
\hline 6 & Países Baixos & 332,23 \\
\hline 7 & Austrália & 328,27 \\
\hline 8 & Suécia & 326,09 \\
\hline 9 & Itália & 323,64 \\
\hline 10 & França & 322,85 \\
\hline 11 & Taiwan & 318,39 \\
\hline 12 & Dinamarca (mais Groenlândia e Ilhas Faeroe) & 315,22 \\
\hline 13 & Coréia do Sul & 314,22 \\
\hline 14 & Finlândia & 310,69 \\
\hline 15 & Suíça & 309,50 \\
\hline 16 & Israel & 307,37 \\
\hline 17 & Áustria & 303,37 \\
\hline 18 & Hong Kong & 303,26 \\
\hline 19 & Nova Zelândia & 298,03 \\
\hline 20 & Noruega & 297,73 \\
\hline 21 & Bélgica & 296,03 \\
\hline 22 & Espanha & 295,44 \\
\hline 23 & Cingapura & 292,73 \\
\hline 24 & Polônia & 280,57 \\
\hline 25 & República Tcheca & 279,96 \\
\hline 26 & Brasil & 269,27 \\
\hline 27 & Estonia & 268,77 \\
\hline 28 & Islândia & 267,89 \\
\hline 29 & República Eslovaca & 266,17 \\
\hline 30 & Luxemburgo & 266,04 \\
\hline 31 & Malásia & 265,49 \\
\hline 32 & Irlanda & 264,84 \\
\hline 33 & Portugal & 264,31 \\
\hline 34 & Hungria & 262,15 \\
\hline 35 & México & 260,65 \\
\hline 36 & Federação Russa & 259,24 \\
\hline 37 & Eslovênia & 257,13 \\
\hline 38 & Chile & 253,78 \\
\hline 39 & Argentina & 250,24 \\
\hline 40 & Romênia & 247,26 \\
\hline 41 & Croácia & 246,77 \\
\hline 42 & Grécia & 245,33 \\
\hline 43 & Letônia & 244,08 \\
\hline 44 & Emirados Árabes Unidos & 242,78 \\
\hline
\end{tabular}




\begin{tabular}{|c|c|c|}
\hline 45 & Lituânia & 241,17 \\
\hline 46 & Turquia & 240,38 \\
\hline 47 & Chipre & 239,97 \\
\hline 48 & Malta & 238,14 \\
\hline 49 & Tailândia & 233,67 \\
\hline 50 & República Popular da China & 232,82 \\
\hline 51 & Bermuda & 232,02 \\
\hline 52 & Bulgária & 231,42 \\
\hline 53 & Uruguai & 231,18 \\
\hline 54 & África do Sul & 227,57 \\
\hline 55 & Costa Rica & 226,15 \\
\hline 56 & Peru & 224,70 \\
\hline 57 & Arábia Saudita & 221,34 \\
\hline 58 & Colômbia & 219,70 \\
\hline 59 & Liechtenstein & 219,29 \\
\hline 60 & Bielo-Russia & 216,88 \\
\hline 61 & República Bolivariana de Venezuela & 213,88 \\
\hline 62 & Koweit & 212,29 \\
\hline 63 & São Marino & 210,03 \\
\hline 64 & Polinésia Francesa & 209,64 \\
\hline 65 & Ucrânia & 209,06 \\
\hline 66 & Sérvia e Montenegro & 208,38 \\
\hline 67 & Líbano & 207,83 \\
\hline 68 & Filipinas & 204,39 \\
\hline 69 & Andorra & 202,24 \\
\hline 70 & Jamaica & 201,31 \\
\hline 71 & Bahrein & 199,18 \\
\hline 72 & Ilhas Vírgens (EUA) & 198,26 \\
\hline 73 & Aruba & 197,96 \\
\hline 74 & Indonésia & 197,49 \\
\hline 75 & Ilhas Maurício & 197,14 \\
\hline 76 & Trinidade e Tobago & 195,94 \\
\hline 77 & Marrocos & 194,86 \\
\hline 78 & Ilhas Caimãs & 194,54 \\
\hline 79 & República Islâmica do Irã & 193,38 \\
\hline 80 & Nova Caledonia & 192,95 \\
\hline 81 & Barbados & 191,79 \\
\hline 82 & Antígua e Barbuda & 190,92 \\
\hline 83 & Brunei Darussalam & 190,05 \\
\hline 84 & República Dominicana & 187,01 \\
\hline 85 & Macau & 186,62 \\
\hline 86 & República Árabe do Egito & 185,49 \\
\hline 87 & Mônaco & 184,83 \\
\hline 88 & Índia & 184,03 \\
\hline 89 & Panamá & 182,21 \\
\hline 90 & Ex-República lugoslava da Macedônia & 182,20 \\
\hline 91 & Ecuador & 182,12 \\
\hline 92 & As Bahamas & 180,83 \\
\hline 93 & Catar & 180,56 \\
\hline
\end{tabular}




\begin{tabular}{|c|c|c|}
\hline 94 & Móldova & 179,99 \\
\hline 95 & El Salvador & 179,38 \\
\hline 96 & Zimbabwe & 179,37 \\
\hline 97 & Samoa Americana & 179,33 \\
\hline 98 & Belize & 179,28 \\
\hline 99 & Jordânia & 178,65 \\
\hline 100 & Bósnia e Herzegovina & 177,44 \\
\hline 101 & Dominica & 175,58 \\
\hline 102 & Porto Rico & 175,43 \\
\hline 103 & Guatemala & 174,63 \\
\hline 104 & Armênia & 174,42 \\
\hline 105 & Cazaquistão & 173,95 \\
\hline 106 & Omã & 173,28 \\
\hline 107 & Guam & 172,38 \\
\hline 108 & Bolívia & 168,11 \\
\hline 109 & Paraguai & 167,54 \\
\hline 110 & Guiana & 167,04 \\
\hline 111 & Seychelles & 166,81 \\
\hline 112 & Tunísia & 164,39 \\
\hline 113 & Namíbia & 163,87 \\
\hline 114 & Geórgia & 162,01 \\
\hline 115 & Santa Lúcia & 160,36 \\
\hline 116 & Mongólia & 159,37 \\
\hline 117 & Ilhas Fiji & 159,34 \\
\hline 118 & Vietnã & 159,29 \\
\hline 119 & Quênia & 159,05 \\
\hline 120 & São Tomé e Príncipe & 158,70 \\
\hline 121 & Uzbequistão & 157,23 \\
\hline 122 & São Kitts e Nevis & 157,06 \\
\hline 123 & Quirguizistão & 156,76 \\
\hline 124 & Nicarágua & 153,27 \\
\hline 125 & Ilhas Maldivas & 153,21 \\
\hline 126 & Botswana & 152,07 \\
\hline 127 & Albânia & 150,96 \\
\hline 128 & Estados Federados da Micronésia & 150,44 \\
\hline 129 & Tuvalu & 149,57 \\
\hline 130 & Tonga & 148,85 \\
\hline 131 & Honduras & 146,14 \\
\hline 132 & Sri Lanka & 145,30 \\
\hline 133 & República Árabe da Síria & 145,26 \\
\hline 134 & Azerbaijão & 144,02 \\
\hline 135 & Suriname & 143,56 \\
\hline 136 & Suazilândia & 141,58 \\
\hline 137 & Cuba & 141,32 \\
\hline 138 & Papua Nova Guiné & 141,23 \\
\hline 139 & Líbia & 137,88 \\
\hline 140 & Senegal & 137,37 \\
\hline 141 & Gaza e Cisjordânia & 137,09 \\
\hline 142 & Argélia & 136,59 \\
\hline
\end{tabular}




\begin{tabular}{|c|c|c|}
\hline 143 & Grenada & 134,90 \\
\hline 144 & Paquistão & 134,55 \\
\hline 145 & Palau & 134,42 \\
\hline 146 & São Vicente e as Granadinas & 131,52 \\
\hline 147 & Samoa & 130,21 \\
\hline 148 & Ilhas Marianas do Norte & 129,71 \\
\hline 149 & Nigéria & 128,10 \\
\hline 150 & Antilhas Holandesas & 127,45 \\
\hline 151 & Zambia & 126,81 \\
\hline 152 & Togo & 125,47 \\
\hline 153 & Costa do Marfim & 123,64 \\
\hline 154 & Cabo Verde & 123,42 \\
\hline 155 & Tanzania & 121,37 \\
\hline 156 & Gabão & 121,12 \\
\hline 157 & Turcomenistão & 119,07 \\
\hline 158 & Lesoto & 118,68 \\
\hline 159 & Butão & 115,79 \\
\hline 160 & Vanuatu & 114,12 \\
\hline 161 & Gana & 110,28 \\
\hline 162 & Moçambique & 109,53 \\
\hline 163 & Haiti & 107,20 \\
\hline 164 & Iêmen & 107,00 \\
\hline 165 & Sudão & 106,37 \\
\hline 166 & Ilhas Salomão & 104,36 \\
\hline 167 & Gâmbia & 103,35 \\
\hline 168 & Nepal & 103,33 \\
\hline 169 & Ilhas Marshall & 101,59 \\
\hline 170 & Uganda & 101,33 \\
\hline 171 & Nauru & 101,04 \\
\hline 172 & Djibouti & 100,67 \\
\hline 173 & Camarões & 99,82 \\
\hline 174 & Benin & 99,32 \\
\hline 175 & Madagascar & 97,10 \\
\hline 176 & Angola & 97,07 \\
\hline 177 & Guiné-Bissau & 96,75 \\
\hline 178 & Ruanda & 94,57 \\
\hline 179 & Laos & 90,98 \\
\hline 180 & Kiribati & 90,32 \\
\hline 181 & República do Congo (Ex-Zaire) & 90,24 \\
\hline 182 & Camboja & 87,44 \\
\hline 183 & Guiné Equatorial & 85,98 \\
\hline 184 & Mauritânia & 84,46 \\
\hline 185 & Somália & 84,20 \\
\hline 186 & Bangladesh & 83,28 \\
\hline 187 & Guiné & 82,02 \\
\hline 188 & Mali & 81,98 \\
\hline 189 & Burundi & 77,77 \\
\hline 190 & Ilhas Comoros & 77,62 \\
\hline 191 & Burkina Faso & 76,29 \\
\hline
\end{tabular}




\begin{tabular}{|l|l|r|}
192 & Malawi & 70,60 \\
\hline 193 & Chade & 68,84 \\
\hline 194 & Iraque & 68,77 \\
\hline 195 & Eritréia & 68,32 \\
\hline 196 & Mayotte & 68,19 \\
\hline 197 & Myanmar & 67,81 \\
\hline 198 & Etiópia & 67,10 \\
\hline 199 & Tadjiquistão & 63,99 \\
\hline 200 & República Democrática do Congo & 59,39 \\
\hline 201 & República Centro-Africana & 58,70 \\
\hline 202 & Serra Leoa & 51,58 \\
\hline 203 & Niger & 48,42 \\
\hline 204 & Libéria & 38,96 \\
\hline
\end{tabular}




\section{5 - Conectividade e Virtualidade: Regulação Mutua}

Como a atitude humana é naturalmente dialética, por um lado tende a estabilizar e padronizar e por outro tende a conturbar a tendência vigente (Alfred North WHITEHEAD, 1929), a Internet surgiu como conseqüência direta de uma necessidade de padronização das ações, de forma coordenada, protocolada, segura e rápida, tendo em vista atender uma demanda iminente. Para se chegar a tal elaboração, foi necessário impulsionar a criação dos meios de conectividade. Nesse mesmo senso, a crescente rapidez com que se exigem as ações tornou essencial incrementar a virtualidade.

A conectividade regula a virtualidade, tendo em vista que a primeira é desenhada conforme os diversos graus de atrito imposto pelas sociedades, bem como pelas características internas a cada uma delas. A virtualidade, portanto, chega aos lugares conforme a conectividade disponível. Em contrapartida, a virtualidade também regula a conectividade, pois a demanda por ações exige mecanismos mais ou menos elaborados ao seu exercício. A demanda por virtualidade, portanto, exige um grau apropriado de conectividade.

Considerando que a virtualidade chega aos lugares de forma diferenciada, devido à conectividade disponível, pode-se concluir que a conectividade é diferenciada, por sua vez, conforme a demanda variável de virtualidade existente pelo mundo. A regulação mutua entre conectividade e virtualidade, em verdade, advém de duas outras regulações, uma entre circulação e território e a outra é a relação mais geral entre técnica e território. Como explanamos anteriormente, em se tratando de um sistema possivelmente "híbrido", existem características típicas da circulação que nos interessam, bem como outras provenientes da comunicação. 


\section{6 - Circulação e Aceleração}

A humanidade chegou ao fim do primeiro terço do século XIX ainda sobre carroças, e saiu do século XX envolvida em um emaranhado de fios e cabos de fibra óptica, que dispensa, em várias ocasiões, até mesmo a circulação física dos diversos sujeitos. A chave para compreender como se chegou a isso está na revolução tecnológica desencadeada pela dominação da eletricidade ${ }^{50}$. Graças à eletricidade, esse descolamento, ou relativa independência entre a circulação de objetos e dos interlocutores (portadores de informação), tornou necessário diferenciar o transporte da comunicação ${ }^{51}$.

Houve, nesse período, três revoluções no ato de circular: a primeira foi a ferroviária, a segunda foi a automobilística e a terceira, a título de especulação, a virtual. A invenção da máquina a vapor permitiu o surgimento da ferrovia, a invenção do motor de combustão permitiu o surgimento dos veículos automotores. A invenção da tecnologia elétrica, e, conseqüentemente, da primeira válvula entre outras tecnologias decorrentes, permitiu o surgimento do primeiro computador.

A evolução na complexidade da operação de circular é central para compreender como o espaço é recriado no tempo presente, e, mesmo, compreender as tendências para o futuro. Um futuro ideal para o capitalismo financeiro seria um meio físico solapado, sem obstáculos ou atritos que desafiassem a engenharia. Seria bem vindo, também, um espaço sem resistências de ordem cultural, social ou econômica. O desejo de que isso aconteça é tamanho que o discurso busca antecipar algo que será pouco provável de acontecer.

O meio físico recebe impactos constantes da introdução das técnicas de circulação em seu âmago, como pudemos verificar no passado, quando tropas de burros foram substituídas por ferrovias, sendo seguidas pelos veículos

\footnotetext{
${ }^{50}$ Até então, "a informação só poderia mover-se na mesma velocidade, e sobre a mesma distância, àquele permitido pelo sistema de transportes em voga" (Peter DICKEN, 1998, pg. 151).

${ }^{51}$ Tornou-se "necessário tratar os transportes e as comunicações, ainda que fossem tecnologias intimamente relacionadas, de forma separada" (Peter DICKEN, 1998, pg. 151). Além disso, "o desenvolvimento em ambas transformou o mundo, permitindo uma mobilidade sem precedentes de materiais e produtos, e uma globalização de mercados" (Peter DICKEN, 1998, pg. 151)
} 
automotores. A automobilística, por sua vez, é parcialmente superada, em diversos aspectos, pela competência e plasticidade do computador. 


\section{7 - A Circulação das Finanças, e a Correlação de Comportamento das Bolsas de Valor no Mundo}

O sistema financeiro mundial se tornou um grande beneficiário do aperfeiçoamento técnico da informática e de suas padronizações nesse período. As negociações poderiam ser muito rápidas e visualizadas em monitores a partir dos escritórios e agências. Nesse sentido, a Internet, seja de forma direta ou indireta, viabilizou novas necessidades e contribuiu para o alargamento dos contextos e à aceleração da história. Hoje, existem bolsas de valores que funcionam durante as 24 horas do dia, pois, graças à grande rede, tornou-se possível fazer negócios em Tóquio a partir de Nova York. O fluxo de capitais deixou de dormir até o dia seguinte para continuar, e não seria difícil supor que existam equipes inteiras de pessoas que trocaram o dia pela noite para exercerem seus expedientes. A divisão do trabalho também sofreu uma complexificação nesse sentido.

A informática permitiu que os computadores se integrassem, de modo que se pudessem homogeneizar as gerências das unidades, e as simulações diversas

pudessem ser compartilhadas com outras unidades. A informática acelerou o fluxo de informações pela extensão das corporações, de modo que as instâncias de decisão ganharam mais poder sobre o comportamento das unidades.

Vejamos que, nesse sentido, através de um estudo empírico que fizemos, há uma considerável correlação de comportamento entre as bolsas de valor do mundo. Isso é um exemplo inato de que a economia global move-se de maneira conjunta. Com o crescente entrelace das parcelas hegemônicas das economias nacionais em uma trama cada vez mais complexa e interdependente, não é de se surpreender que o comportamento de instituições financeiras pelo mundo possa se assemelhar em diversos aspectos. Um impacto que ocorra em um ponto dessa rede poderá afetar a todos, de acordo com o grau de interdependência entre as instituições envolvidas.

As bolsas de valor são um indicador interessante para se estudar, pois emitem diariamente seus índices. Estes índices podem revelar muito mais do que apenas 
a média ou um cômputo das movimentações do dia, o que orienta os interesses do capitalismo financeiro pelo globo. Podem, talvez, nos revelar os graus de interdependência entre si, permitindo-nos especular a respeito de um possível indicador de globalização, isto é, de um tempo uno entre as economias.

Os anos de 1980 foram emblemáticos, pois, à esteira das tendências do neoliberalismo (inicialmente nos EUA e no Reino Unido), as articulações entre os agentes financeiros internacionais se tornaram mais fortes em detrimento dos preceitos dos Estados, e, simultaneamente, os mecanismos que permitissem a maior fluidez dos capitais foram sendo incentivados. Disso resulta que problemas de uma instituição, dependendo de sua centralidade ou setor, podem afetar, cada vez mais, outras instituições (inclusive Estados), conforme os graus de entrelace no sistema. A fluidez permite a fuga ou a introdução de capitais em situações propícias, garantindo maior segurança e retorno aos especuladores. Assim, um impacto, seja este positivo ou negativo, em um local, pode afetar o estado financeiro de uma ou mais instituições em outro ponto do planeta, e de forma quase imediata.

Além, é claro, do fim da era bipolar, em que o leste da Europa iria gradativamente se integrar ao sistema capitalista, os anos entre 1989 e 2001 foram caracterizados pela grande acessibilidade ao computador pessoal e pela liberação da Internet ao uso do grande público. Isso faria com que uma parcela das sociedades passassem a usufruir dos mecanismos da fluidez para seus propósitos. Tal mecanismo permitiria revolucionar o comércio, bem como diversas outras modalidades da interação humana, principalmente afetando o comportamento das classes médias e altas dos países. Isso tudo ocorreu conforme uma estratégia de buscar a aceleração das micro-economias, de modo que pudessem deixar de refrear tanto as ações dos atores hegemônicos do período, e torná-los cada vez mais subservientes aos seus preceitos. A aceleração das sociedades serve aos propósitos dos atores centrais do sistema, visto que o consumo e a produção se aceleram, impulsionando assim a acumulação.

A partir de 2001, uma grave crise da indústria da informática (acusado pelo índice NASDAQ de Nova York), fruto de uma especulação decorrente do otimismo 
daqueles que enxergavam a história como algo linear e irreversível, e os impensáveis atentados terroristas em Nova York e Washington, afetaram todo o sistema político e econômico mundial. Um otimismo, de aparência quase ingênua, cedeu lugar ao ceticismo e cinismo generalizados, isto é, instaurou-se um realismo empolgado e agressivo. A Internet, hoje uma rede de imensa capilaridade sobreposta ao globo, passou a ser visto novamente como um mecanismo bastante parecido com o ideal que despertou o interesse pela sua criação, isto é, um sistema de controle, porém, de informações de seus usuários, e não mais de instalações essenciais à manutenção de um governo. Ainda que esse objetivo tenha sido renovado, os vetores do desenvolvimento da indústria de informática e do capitalismo financeiro não se intimidaram, e prosseguiram no fomento da fluidez e da aceleração, gerando uma crescente vertigem.

É preciso, portanto, reconhecer se realmente há uma convergência no sistema financeiro, bem como se existe um comportamento que possa evidenciar alguma simetria, mesmo que em linhas gerais, dos índices mundiais, devido ao grau de correlação que se pode supor nesse sentido.

Como ferramenta central de nossa análise, utilizamos a análise de correlação desenvolvida pelo estatístico inglês Karl Pearson (1857-1936). O chamado coeficiente de correlação varia exclusivamente entre -1.0 e 1.0 (ou $-100 \%$ e $100 \%$ ), e o sinal indica uma correlação positiva (paralela, de mesma tendência) ou negativa (tendência inversa, espelho da outra ao comparar o gráfico entre duas variáveis). As correlações tidas como altas são aquelas que variam entre $75 \%$ a $100 \%$, tanto negativos como positivos, e abaixo disso (entre $-75 \%$ e $75 \%$ ) a correlação é interpretada como pouco ou nada confiável. Caso haja interesse no aprofundamento do assunto e nas fórmulas utilizadas para o cálculo, recomendamos o sítio http://mathworld.wolfram.com/CorrelationCoefficient.html, cuja referência completa aparece em nossa bibliografia.

Para podermos evidenciar comportamentos correlatos, partimos do princípio de que seria necessário quantificar a análise, utilizando-se, como matéria bruta, as séries históricas das bolsas de valor. Estas séries encontram-se disponíveis, 
gratuitamente, para o público no sítio de Internet do Yahoo! Finance (http://finance.yahoo.com/intlindices).

A partir do sítio do Yahoo! Finance, selecionamos 23 cidades (três da América Latina, duas da América do Norte, nove da Ásia, oito da Europa e uma da Oceania) que julgamos as mais importantes para integrarmos o universo de análise. Outras cidades simplesmente foram excluídas devido à indisponibilidade de dados suficientemente extensos, ainda que fôssem interessantes para a análise, a exemplo do Santiago do Chile e Bangcoc na Tailândia. Buscamos, então, correlacionar as séries históricas dos seguintes índices:

\begin{tabular}{|l|l|l|l|}
\hline Cidade & Nome & Cidade & Nome \\
\hline São Paulo & Bovespa & Cingapura & Straits Times \\
\hline Buenos Aires & MerVal & Seul & Seoul Composite \\
\hline C. do México & IPC & Taipei & Taiwan Weighted \\
\hline Nova York & S\&P 500 Index & Paris & CAC 40 \\
\hline Toronto & S\&P TSX Composite & Frankfurt & XETRA DAX \\
\hline Xangai & Shanghai Composite & Milão & MIBTel \\
\hline Sydney & All Ordinaries & Amsterdã & AEX General \\
\hline Hong Kong & Hang Seng & Moscou & Moscow Times \\
\hline Mumbai & BSE 30 & Zurique & Swiss Market \\
\hline Jacarta & Jakarta Composite & Londres & Financial Times SE \\
\hline Tóquio & Nikkei 225 & Madri & Madrid General \\
\hline Kuala Lumpur & KLSE Composite & & \multicolumn{1}{|l}{} \\
\cline { 1 - 2 } & \multicolumn{2}{|l}{} &
\end{tabular}

Tabela 2 - RELAÇÃO DAS BOLSAS DE VALOR UTILIZADAS NOS TRABALHOS DE CORRELAÇÃO

As correlações entre esses 23 índices resultam em 253 cruzamentos, ou eixos, como convencionamos chamar daqui para frente.

Ainda que as séries históricas fôssem relativamente extensas, verificamos algumas descontinuidades, cujos casos mais extremos aconteceram nos registros de Xangai, provavelmente por conta de eventuais intervenções governamentais e de tradições (o ano novo chinês). Invariavelmente, optamos por "sustentar" a última cotação pelo período necessário, de modo a obtermos uma continuidade e uma paridade com as séries a serem correlacionadas entre si. 
Os 23 indices podem ser divididos em três grupos: um bastante extenso, outro intermediário e outro curto (mas representativo). Os eixos foram estabelecidos e correlacionados conforme a cidade de menor série histórica entre cada par. Assim, se uma cidade tivesse uma série histórica curta, e outra uma série intermediária, a correlação é estabelecida conforme a extensão da série curta.

As séries mais longas duram de $1^{\circ}$ de janeiro de 1990 a 8 de novembro de 2004, enquanto as mais curtas duram do último terço da década de 1990 em diante, e o grupo intermediário parte dos meados dos anos 1990. Impreterivelmente, o dia 8 de novembro de 2004 é o limite mais atual de todas as nossas análises, e é a data comum para o encerramento de todos os índices em nosso levantamento.

Com intuito de retratar a semelhança de comportamentos, buscamos correlacionar os índices também nos dias que precederam e sucederam eventos marcantes da história recente, tais como eleições, atentados terroristas, crises econômicas e guerras.

Podemos atestar que todos os cinco eixos que acusaram as maiores correlações positivas do período estudado foram aqueles que envolveram cidades européias, como se pode verificar na tabela abaixo:

\begin{tabular}{|c|c|c|}
\hline \multicolumn{2}{|c|}{ Eixo } & Correlação \\
\hline Frankfurt & Amsterdã & $98,7 \%$ \\
\hline Londres & Amsterdã & $98,1 \%$ \\
\hline Londres & Zurique & $97,8 \%$ \\
\hline Paris & Milão & $97,8 \%$ \\
\hline Paris & Frankfurt & $97,4 \%$ \\
\hline
\end{tabular}

Tabela 3 - MAIORES EIXOS DE CORRELAÇÃO POSITIVA (01/1990-11/2004)

É importante relembrar que as correlações positivas indicam paralelismo de comportamento, e índices acima de $75 \%$ são tidas como altas.

Entre os cinco eixos que apresentaram as maiores correlações negativas em todo o conjunto, isto é, um efeito inverso entre pares, quatro delas apresentaram cidades asiáticas, e apenas um eixo era exclusivamente europeu. A maior correlação negativa, ainda assim, não chega a beirar o limiar de $75 \%$, o que pode 
indicar a existência de uma grande tendência ao paralelismo, ainda que os efeitos inversos existam e possuam relativa importância:

\begin{tabular}{|c|c|c|}
\hline \multicolumn{2}{|c|}{ Eixo } & Correlação \\
\hline Kuala Lumpur & Zurique & $-66,6 \%$ \\
\hline Tóquio & Moscou & $-68,2 \%$ \\
\hline México & Tóquio & $-68,6 \%$ \\
\hline Moscou & Londres & $-69,6 \%$ \\
\hline Sydney & Tóquio & $-74,0 \%$ \\
\hline
\end{tabular}

Tabela 4 - MAIORES EIXOS DE CORRELAÇÃO NEGATIVA (01/1990-11/2004)

De grosso modo, pode-se concluir que um determinado contexto que afete a economia dos principais centros da Europa produz, com relativa causalidade, um efeito contrário em alguns centros do resto do mundo, e o inverso também é verdadeiro. Também se pode considerar que esse efeito inverso só tem alguma importância se envolver eixos euro-asiáticos. Se levarmos em conta que a economia da Oceania como um todo ainda é bastante articulado à da Europa (embora de forma crescente com a Ásia), não é surpresa a existência de uma correlação inversa no eixo Sydney-Tóquio $(-74,0 \%)$, aliás, a maior de todos os eixos.

Nas Américas, o quadro é esmagadoramente voltado para correlações positivas, nesse caso, indicando a interdependência entre as economias do hemisfério. Das cinco maiores correlações que foram apuradas para o período, a BOVESPA (São Paulo) e a bolsa de Toronto apareceram em três cada uma. As cinco maiores correlações positivas são as seguintes:

\begin{tabular}{|c|c|c|}
\hline \multicolumn{2}{|c|}{ Eixo } & Correlação \\
\hline São Paulo & México & $95,3 \%$ \\
\hline Nova York & Toronto & $95,0 \%$ \\
\hline São Paulo & Toronto & $90,5 \%$ \\
\hline México & Toronto & $87,0 \%$ \\
\hline São Paulo & Nova York & $79,7 \%$ \\
\hline
\end{tabular}

Tabela 5 - MAIORES EIXOS DE CORRELAÇÃO POSITIVA, AMÉRICAS (01/1990-11/2004) 
É importante mencionar a correlação entre as bolsas de São Paulo e da cidade do México no período.

Diferente do que pudemos verificar entre as bolsas do restante do mundo, acusamos apenas uma única correlação negativa nas Américas, que é insignificante e débil (Buenos Aires-Nova York, -20,2\%), visto que está longe do limiar de confiança.

Tanto no caso das Américas como o euro-asiático, as correlações positivas são as mais expressivas, havendo números muito acima do limiar, o que indica maior paralelismo e dependência. Isto significa dizer que um efeito positivo em uma das bolsas tende a beneficiar mais do que prejudicar, contudo, o inverso também se aplica, i.e., se uma bolsa entra em crise, esta tenderá a contaminar os demais índices, e é bem menos provável que beneficie alguém.

As correlações de alguns segmentos selecionados do período estudado também são interessantes de se verificar.

Entre abril de 1993 e abril de 1996, os eixos de maior correlação positiva envolveram os de cidades européias ocidentais, juntamente com a bolsa de Toronto. Apenas o oitavo maior eixo envolve outra cidade (Nova York-Londres, 91,1\%). O período, portanto, foi caracterizado por uma proximidade de comportamento da bolsa canadense com as bolsas de Frankfurt, Amsterdã, Londres e Zurique. Neste período, também, nenhuma correlação negativa superou o limiar. Vejamos a situação desse período:

\begin{tabular}{|c|c|c|}
\hline \multicolumn{2}{|c|}{ Eixo } & Correlação \\
\hline Frankfurt & Amsterdã & $94,06 \%$ \\
\hline Toronto & Amsterdã & $94,01 \%$ \\
\hline Toronto & Londres & $93,65 \%$ \\
\hline Zurique & Londres & $93,45 \%$ \\
\hline Amsterdã & Zurique & $92,28 \%$ \\
\hline Toronto & Zurique & $92,17 \%$ \\
\hline Amsterdã & Londres & $92,12 \%$ \\
\hline Nova York & Londres & $91,08 \%$ \\
\hline Sydney & Hong Kong & $91,05 \%$ \\
\hline Nova York & Toronto & $89,17 \%$ \\
\hline Frankfurt & Zurique & $88,26 \%$ \\
\hline
\end{tabular}

Tabela 6 - MAIORES EIXOS DE CORRELAÇÃO POSITIVA (04/1993-04/1996) 
Um segmento seguinte foi o de novembro de 1996 a agosto de 1997. O eixo Frankfurt-Amsterdã permaneceu como o de correlação mais alta (99,5\%), mas as correlações altas são ainda maiores do que no período anterior. Os dez eixos de maior correlação deste período superam em pelo menos $2 \%$ o eixo de maior correlação do período anterior. As bolsas de São Paulo, Nova York e Paris se mesclam às cidades que já apresentavam essa correlação alta.

Outra característica deste segundo período é que as correlações negativas são expressivas, sendo que dezesseis delas superaram o limiar, isto é, são relevantes. Dentre essas correlações negativas, pôde-se verificar que todas apresentaram como componente de eixo ao menos uma cidade asiática. A bolsa de Cingapura foi a que apareceu nas sete maiores correlações inversas, envolvendo cidades da Europa Ocidental e América Latina. Não menos importante é notabilizar os eixos São Paulo-Zurique $(97,7 \%)$, o quarto maior do período, e o eixo Nova YorkToronto $(97,4 \%)$, quinto maior do período e eixo de maior correlação nas Américas. Vejamos a situação deste período:

\begin{tabular}{|c|c|c|c|c|c|}
\hline \multicolumn{2}{|c|}{ Correlações Positivas } & \multicolumn{2}{c|}{ Correlações Negativas } \\
\hline \multicolumn{2}{|c|}{ Eixo } & Correl. & Eixo & \multicolumn{2}{c|}{ Correl. } \\
\hline Frankfurt & Amsterdã & $99,46 \%$ & Nova York & Cingapura & $-79,10 \%$ \\
\hline Amsterdã & Zurique & $97,90 \%$ & Kuala Lumpur & Londres & $-81,20 \%$ \\
\hline Frankfurt & Zurique & $97,72 \%$ & Kuala Lumpur & Frankfurt & $-81,21 \%$ \\
\hline São Paulo & Zurique & $97,71 \%$ & Kuala Lumpur & México & $-81,32 \%$ \\
\hline Nova York & Toronto & $97,40 \%$ & Buenos Aires & Cingapura & $-81,80 \%$ \\
\hline Frankfurt & Londres & $97,03 \%$ & México & Cingapura & $-82,02 \%$ \\
\hline Amsterdã & Londres & $96,82 \%$ & São Paulo & Cingapura & $-83,37 \%$ \\
\hline Nova York & Sydney & $96,73 \%$ & Cingapura & Londres & $-83,81 \%$ \\
\hline Paris & Amsterdã & $96,58 \%$ & Cingapura & Amsterdã & $-84,80 \%$ \\
\hline Paris & Frankfurt & $96,56 \%$ & Cingapura & Zurique & $-86,32 \%$ \\
\hline México & Amsterdã & $96,54 \%$ & Cingapura & Frankfurt & $-87,12 \%$ \\
\hline
\end{tabular}

Tabela 7 - MAIORES EIXOS DE CORRELAÇÃO POSITIVA (11/1996-08/1997)

É interessante notar que as correlações, tanto negativas como positivas, apresentaram uma acentuação de tendência, o que indica um período de maior interdependência dos índices. Quanto mais distantes de zero, seja para mais ou 
para menos, as correlações revelam maior interdependência das variáveis envolvidas.

O terceiro período que nós propusemos apresentar estende-se de dezembro de 1997 a dezembro de 1999, e foi caracterizado pela liderança das fortes correlações nos eixos Hong Kong-Cingapura $(97,4 \%)$ e Cingapura-Seul $(95,8 \%)$. Ao contrário dos períodos precedentes, em que os eixos envolvendo as bolsas européias ocuparam as duas primeiras posições, neste período o eixo ParisAmsterdã aparece apenas em terceiro (94,1\%), e um eixo Madri-México em quinto lugar (92,9\%). É um período de maiores correlações inter-asiáticas. Diferente do período anterior, o eixo de correlação mais importante das Américas passou a ser latino-americano, o de São Paulo-México (93,9\%). Este terceiro período ainda se caracteriza pela insignificância nas correlações negativas.

Vejamos, então, a seguinte tabela, referente a esse terceiro período:

\begin{tabular}{|c|c|c|c|c|c|}
\hline \multicolumn{2}{|c|}{ Eixo } & Correlação & Eixo & \multicolumn{2}{c|}{ Correlação } \\
\hline Hong Kong & Cingapura & $97,36 \%$ & Hong Kong & Seul & $92,57 \%$ \\
\hline Cingapura & Seul & $95,80 \%$ & Milão & Amsterdã & $92,30 \%$ \\
\hline Paris & Amsterdã & $94,10 \%$ & Cingapura & Moscou & $91,75 \%$ \\
\hline São Paulo & México & $93,87 \%$ & Sydney & Londres & $91,74 \%$ \\
\hline México & Madri & $92,94 \%$ & México & Moscou & $91,51 \%$ \\
\hline Nova York & Sydney & $92,82 \%$ & \multicolumn{3}{|l}{} \\
\cline { 1 - 2 } & &
\end{tabular}

Tabela 8 - MAIORES EIXOS DE CORRELAÇÃO POSITIVA (12/1997-12/1999)

O quarto segmento que separamos para demonstrar estende-se de maio de 2000 a maio de 2001. No quadro das correlações, a participação da bolsa de Paris nos eixos mais fortes foi ressaltada, contudo, o eixo mais forte a envolve com Nova York (97,7\%). A bolsa de Paris participa de dois dos três maiores eixos seguintes, mas em articulações circunsunscritas à Europa. Dos doze maiores eixos de correlação, a cidade de Nova York apresenta-se em cinco destes, sendo quatro formados com cidades européias. Não há cidades asiáticas entre os doze maiores eixos de correlação positiva. Contudo, ficou patente que Xangai formou eixos de correlação negativa com nove cidades pelo mundo, porém oito destes inferiores 
ao limiar. O único eixo negativo e acima do limiar foi formado com Kuala Lumpur ($80,2 \%)$. Segue a tabela das maiores correlações deste período:

\begin{tabular}{|l|l|l|l|l|l|}
\hline \multicolumn{3}{|c|}{ Correlações Positivas } & \multicolumn{2}{c|}{ Correlações Positivas (cont.) } \\
\hline \multicolumn{2}{|c|}{ Eixo } & Correl. & \multicolumn{2}{c|}{ Eixo } & \multicolumn{2}{c|}{ Correl. } \\
\hline Nova York & Paris & $97,71 \%$ & Nova York & Amsterdã & $94,69 \%$ \\
\hline Milão & Amsterdã & $96,88 \%$ & Nova York & Toronto & $94,07 \%$ \\
\hline Paris & Frankfurt & $96,38 \%$ & Frankfurt & Amsterdã & $93,79 \%$ \\
\hline Paris & Amsterdã & $96,22 \%$ & Milão & Londres & $93,69 \%$ \\
\hline Amsterdã & Londres & $95,77 \%$ & Paris & Londres & $93,21 \%$ \\
\hline Nova York & Frankfurt & $95,65 \%$ & Nova York & Londres & $92,89 \%$ \\
\hline
\end{tabular}

Tabela 9 - MAIORES EIXOS DE CORRELAÇÃO POSITIVA (12/1997-12/1999)

Nesse período, também, nenhuma cidade latino-americana apareceu em qualquer dos extremos, revelando um período em que a articulação dos eixos que as envolviam estavam um tanto débeis, enfraquecidas.

Desde os atentados ao World Trade Center, em 11 de setembro de 2001, neste quinto e atual período, os maiores eixos de correlação se concentraram novamente na Europa. As bolsas de Paris e de Frankfurt passam a se articular em três dos cinco eixos primeiros colocados no período, enquanto Nova York aparece mais embaixo, em apenas um dos onze maiores eixos, articulado com Madri (96,4\%). Um eixo de correlação que despertou curiosidade foi aquele identificado entre México e Jacarta (97,0\%), um verdadeiro "outlier", que mereceria maior investigação em outra oportunidade. Novamente, as correlações inversas são insignificantes, i.e., baixas demais para serem consideradas. Vejamos então a situação mais atual do conjunto dos eixos de correlação estudados: 


\begin{tabular}{|l|l|l|}
\hline \multicolumn{2}{|c|}{ Eixo } & Correlação \\
\hline Paris & Londres & $98,76 \%$ \\
\hline Paris & Frankfurt & $98,68 \%$ \\
\hline Frankfurt & Londres & $97,84 \%$ \\
\hline Frankfurt & Zurique & $97,78 \%$ \\
\hline Paris & Zurique & $97,06 \%$ \\
\hline México & Jacarta & $96,96 \%$ \\
\hline Zurique & Londres & $96,59 \%$ \\
\hline Nova York & Madri & $96,40 \%$ \\
\hline Frankfurt & Milão & $96,21 \%$ \\
\hline Paris & Milão & $96,00 \%$ \\
\hline Milão & Zurique & $95,95 \%$ \\
\hline
\end{tabular}

Tabela 10 - MAIORES EIXOS DE CORRELAÇÃO POSITIVA (09/2001-11/2004)

Em nossa análise quantitativa, fizemos também um cômputo relativo às quantidades de eixos de correlação que estivessem acima de $85 \%$, algo que aparentemente exclui uma linearidade de convergência, mas evidencia, ao que parece, uma convergência eventual, conforme um contexto determinado e propício. Veja o gráfico a seguir.

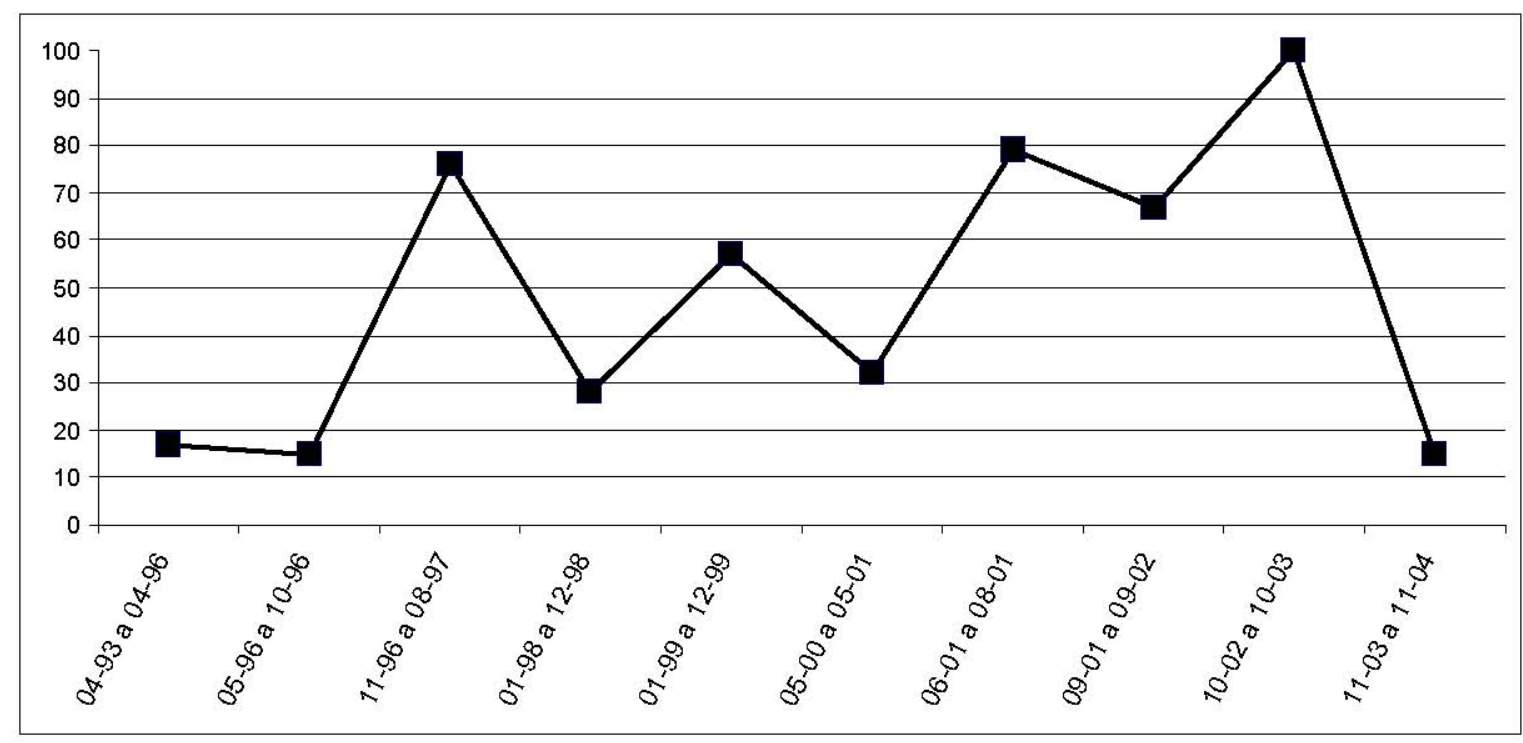

FIGURA 6 - QUANTIDADE DE EIXOS DE CORRELAÇÃO ACIMA DE 85\% EXISTENTES EM CADA PERÍODO (04/1993-11/2004)

O fato é que se realmente houvesse uma convergência linear e não ocasional, isto é, temporária, estaríamos diante de um gráfico exclusivamente crescente, mesmo 
que com certas quedas ocasionais. A inexistência de uma convergência linear é ainda mais evidente quando verificamos que no período de outubro de 2002 e outubro de 2003, o pico de todo o período estudado nesse gráfico, não atinge 50\% dos eixos estudados (apenas 100 eixos acima de 85\%, de um total de 234). A julgar também pela extensão dos períodos, o gráfico deveria demonstrar alguma linearidade caso houvesse.

O que se pode afirmar é a existência de convergências ocasionais e alternantes, mas obedientes, é claro, aos preceitos dos atores hegemônicos da Globalização. O capitalismo financeiro não parece buscar a homogeneização dos lugares sob o ponto de vista dos juros e dos retornos, mas sim a existência de diferenciais e de desigualdades, para justamente permitir a especulação, a distração dos concorrentes e a acumulação. A existência de uma convergência linear e histórica dos índices faria com que a tendência do capital fosse o de parar de circular, até que se chegasse a provocar uma "congestão" do sistema.

Uma ausência sentida, em diversas ocasiões, dos índices que se comportassem como "espelhos" de outros, o que comprovaria numericamente que enquanto um lugar ganha o outro perde, nos parece ter lógica, visto que a convergência é ocasional, de tempo mais curto, imediatista. Neste sentido, selecionamos alguns fatos históricos recentes para retratar que os modelos de interpretação funcionam melhor em períodos curtos, visto que a convergência é ocasional. Vejamos então o que a tabela a seguir pode nos esclarecer a esse respeito. 


\begin{tabular}{|l|c|c|c|}
\hline \multicolumn{1}{|c|}{ Evento } & Data & $\begin{array}{c}\text { Correlações } \\
\text { Positivas } \\
\text { Acima de 80\% }\end{array}$ & $\begin{array}{c}\text { Correlações } \\
\text { Negativas } \\
\text { Acima de 80\% }\end{array}$ \\
\hline $\begin{array}{l}\text { Crise do México, desvalorização de } \\
60 \% \text { do Peso }\end{array}$ & $15 / 1 / 1995$ & 5 & 3 \\
\hline $\begin{array}{l}\text { Eleição de Hugo Chavez (primeiro } \\
\text { mandato) }\end{array}$ & Dezembro de 1998 & 56 & 8 \\
\hline $\begin{array}{l}\text { Crise Monetária no Brasil, Moratória } \\
\text { do Estado de Minas Gerais }\end{array}$ & $13 / 1 / 1999$ & 22 & 5 \\
\hline $\begin{array}{l}\text { Destruição da Embaixada Chinesa } \\
\text { em Belgrado }\end{array}$ & $7 / 11 / 1999$ & 119 & 16 \\
\hline $\begin{array}{l}\text { Crise Argentina, Ministro Machinea } \\
\text { assume superação de metas fiscais }\end{array}$ & $18 / 8 / 2000$ & 32 & 0 \\
\hline $\begin{array}{l}\text { Eleições dos EUA em 2000, litígio } \\
\text { eleitoral no Estado da Flórida }\end{array}$ & $2 / 11 / 2000$ & 19 & 2 \\
\hline Atentados a Washington e Nova York & $11 / 9 / 2001$ & 170 & 0 \\
\hline Invasão ao Afeganistão & $7 / 10 / 2001$ & 106 & 0 \\
\hline Implantação do Euro, pela UE & $1 / 1 / 2002$ & 44 & 9 \\
\hline Eleição de Luis Inácio Lula da Silva & $28 / 10 / 2002$ & 70 & 12 \\
\hline Invasão ao Iraque & $19 / 3 / 2003$ & 42 & 4 \\
\hline Atentados em Madri & $11 / 3 / 2004$ & 33 & 3 \\
\hline $\begin{array}{l}\text { Eleições dos EUA em 2004, reeleição } \\
\text { de George W. Bush }\end{array}$ & $2 / 11 / 2004$ & 149 & 0 \\
\hline
\end{tabular}

Tabela 11- EIXOS DE CORRELAÇÕES POSITIVAS E NEGATIVAS ESTUDADOS NO DECORRER DE EVENTOS HISTÓRICOS RELEVANTES: QUANTIDADES DE CORRELAÇÕES POSITIVAS E NEGATIVAS

Percebe-se que nesta tabela as correlações positivas se tornam muito mais expressivas, justamente pela resposta aos fatos serem mais articulada entre os eixos. As correlações negativas ficam ocasionalmente mais pronunciadas, mas ficam mais evidentes se comparados à análise mais extensa, em forma de períodos mais longos. A tabela leva em conta um período de cinco semanas antes e cinco semanas depois da data que elegemos como central na questão. A tabela à seguir faz o mesmo, contudo, demonstrando o continente que acumula mais cidades que estejam entre os cinco eixos mais correlacionados, e quais foram os eixos de correlação de cada extremidade da estatística na ocasião. 


\begin{tabular}{|c|c|c|c|c|}
\hline \multirow{2}{*}{ Evento } & \multirow{2}{*}{ Data } & \multirow{2}{*}{$\begin{array}{c}\text { Continente com } \\
\text { maior presença } \\
\text { nas } 5 \text { maiores } \\
\text { correlações }\end{array}$} & \multicolumn{2}{|c|}{ Maior correlação } \\
\hline & & & $\begin{array}{c}\text { Positiva } \\
\text { (Paralelismo) }\end{array}$ & Negativa (Espelho) \\
\hline $\begin{array}{l}\text { Crise do México, desvalorização de } \\
60 \% \text { do Peso }\end{array}$ & $15 / 1 / 1995$ & Ásia (4 cidades) & $\begin{array}{l}\text { México-Tóquio } \\
(96,76 \%)\end{array}$ & $\begin{array}{c}\text { México-Nova York } \\
(93,73 \%)\end{array}$ \\
\hline $\begin{array}{l}\text { Eleição de Hugo Chavez (primeiro } \\
\text { mandato) }\end{array}$ & Dezembro de 1998 & Europa ( 4 cidades) & $\begin{array}{l}\text { São Paulo-Buenos } \\
\text { Aires }(98,94 \%)\end{array}$ & $\begin{array}{c}\text { Kuala Lumpur-Taipe } \\
(95,78 \%)\end{array}$ \\
\hline $\begin{array}{l}\text { Crise Monetária no Brasil, Moratória } \\
\text { do Estado de Minas Gerais }\end{array}$ & $13 / 1 / 1999$ & Europa ( 4 cidades) & $\begin{array}{c}\text { Nova York-Paris } \\
(92,20 \%)\end{array}$ & $\begin{array}{c}\text { Sydney-Taipei } \\
(91,48 \%)\end{array}$ \\
\hline $\begin{array}{l}\text { Destruição da Embaixada Chinesa } \\
\text { em Belgrado }\end{array}$ & $7 / 11 / 1999$ & Europa ( 4 cidades) & $\begin{array}{c}\text { Frankfurt-Amsterdã } \\
(99,53 \%)\end{array}$ & $\begin{array}{c}\text { Xangai-Londres } \\
(95,60 \%)\end{array}$ \\
\hline $\begin{array}{l}\text { Crise Argentina, Ministro Machinea } \\
\text { assume superação de metas fiscais }\end{array}$ & $18 / 8 / 2000$ & Ásia (4 cidades) & $\begin{array}{c}\text { Jacarta-Taipei } \\
(94,68 \%) \\
\end{array}$ & $\begin{array}{c}\text { Buenos Aires- } \\
\text { Zurique }(65,41 \%)\end{array}$ \\
\hline $\begin{array}{l}\text { Eleições dos EUA em 2000, litígio } \\
\text { eleitoral no Estado da Flórida }\end{array}$ & $2 / 11 / 2000$ & Europa ( 4 cidades) & $\begin{array}{c}\text { México-Londres } \\
(93,38 \%)\end{array}$ & $\begin{array}{c}\text { Toronto-Xangai } \\
(87,05 \%)\end{array}$ \\
\hline Atentados a Washington e Nova York & $11 / 9 / 2001$ & Europa ( 4 cidades) & $\begin{array}{l}\text { Paris-Frankfurt } \\
(99,71 \%)\end{array}$ & Não Houve \\
\hline Invasão ao Afeganistão & $7 / 10 / 2001$ & Europa ( 5 cidades) & $\begin{array}{l}\text { Paris-Frankfurt } \\
(98,94 \%)\end{array}$ & $\begin{array}{c}\text { Nova York-Xangai } \\
(68,59 \%)\end{array}$ \\
\hline Implantação do Euro, pela UE & $1 / 1 / 2002$ & Ásia (4 cidades) & $\begin{array}{l}\text { Nova York-Paris } \\
(95,59 \%)\end{array}$ & $\begin{array}{c}\text { Buenos Aires- } \\
\text { Xangai }(91,99 \%)\end{array}$ \\
\hline Eleição de Luis Inácio Lula da Silva & $28 / 10 / 2002$ & Europa ( 5 cidades) & $\begin{array}{c}\text { Paris-Frankfurt } \\
(98,73 \%)\end{array}$ & $\begin{array}{c}\text { Buenos Aires- } \\
\text { Xangai }(93,43 \%)\end{array}$ \\
\hline Invasão ao Iraque & $19 / 3 / 2003$ & Europa ( 5 cidades) & $\begin{array}{c}\text { Nova York-Londres } \\
(94,98 \%)\end{array}$ & $\begin{array}{l}\text { México-Tóquio } \\
(87,45 \%)\end{array}$ \\
\hline Atentados em Madri & $11 / 3 / 2004$ & Europa ( 4 cidades) & $\begin{array}{l}\text { Nova York-Londres } \\
(94,96 \%)\end{array}$ & $\begin{array}{l}\text { Mexico-Toquio } \\
(84,42 \%)\end{array}$ \\
\hline $\begin{array}{l}\text { Eleições dos EUA em 2004, reeleição } \\
\text { de George W. Bush }\end{array}$ & $2 / 11 / 2004$ & Europa ( 4 cidades) & $\begin{array}{c}\text { Paris-Frankfurt } \\
(99,88 \%)\end{array}$ & $\begin{array}{c}\text { Xangai-Moscou } \\
(72,55 \%)\end{array}$ \\
\hline
\end{tabular}

Tabela 12 - EIXOS DE CORRELAÇÕES POSITIVAS E NEGATIVAS ESTUDADAS NO DECORRER DE EVENTOS HISTÓRICOS RELEVANTES: CONTINENTES E CIDADES

Este gráfico certamente retrata que, realmente, um lugar às vezes distante pode ganhar ou perder em função da situação que evolui em outro. A questão é que isto só consegue se demonstrado em curtas porções do tempo. As séries históricas não demonstram a convergência, enquanto as séries curtas demonstram bem a articulação e a interdependência.

Afinal, as bolsas de valor podem ser consideradas um indicador de globalização? Ainda que as séries históricas por si só, em correlação, neguem a suspeitada convergência linear histórica, o fato é que existem convergências ocasionais e alternadas, que atestam a possibilidade de utilizar tais índices financeiros como um "índice", ou "indicador" de como prossegue a Globalização. A questão da velocidade talvez tenha chegado ao ponto de termos que considerar um indicador diário da Globalização (algo num período de horas, por exemplo), visto que a sucessão de eventos e a pronta reação do mercado mundial perante estes geram fluxos positivos e negativos, atingindo de forma diferenciada os lugares. A escala 
e a escalada dos eventos tornam uma interpretação de longa duração pouco explicativa, ainda que permita apresentar as linhas gerais do nexo que conduz um determinado período.

Em contrapartida aos movimentos complexos dos capitais pelo mundo, as horizontalidades também se beneficiaram das inovações da microinformática. As organizações não-governamentais, as associações profissionais, estudantis, acadêmicas e mesmo reivindicatórias passariam a contar com as mesmas tecnologias de comunicação, a mesma eficácia e a mesma eficiência. 


\section{8 - Técnica, Circulação e a Divisão Territorial do Trabalho}

O pensar e o imaginar permitem o surgimento de utopias, teorias e necessidades futuras, tendo em vista a superação das dificuldades do presente, principalmente referentes ao trabalho. Busca-se, portanto, a superação de fatores limitantes, sejam estes referentes aos capitais, à produtividade ou até mesmo ao próprio modo de produção como um todo. Assim surgem as técnicas e as suas decorrências, que implicam na substituição dos modos antigos e na resistência destes à inovação ${ }^{52}$. A conjunção de fatores, que compõem um contexto, propicia ou resiste à difusão das técnicas pelos territórios. Além de resistências de ordem moral, ética e até mesmo religiosa, existe a resistência econômica, devido ao alto custo na implantação de uma inovação qualquer. É evidente que se o retorno de uma implantação qualquer valer a pena, dificilmente se deixará de lançar mão dela ${ }^{53}$. Contudo, sem uma conjunção de fatores políticos, isto é, um contexto político favorável, a ladeira a ser subida torna-se mais íngreme ou até mesmo impossível de se subir. A fluidez do território e, por conseguinte, a difusão da técnica, depende da soma de fatores capazes de concretizar e perpetuar uma infra-estrutura qualquer, não importando a envergadura ${ }^{54}$. Evidente que se depende fundamentalmente do Estado para gerar e gerir as infra-estruturas, visto que a diversidade de opinião e de interesse dos indivíduos torna uma eventual assembléia infrutífera. Daí vem a justificativa de uma política representativa. O poder de persuasão dos atores hegemônicos se encarregará de nortear as decisões do Estado. Além do mais, isso é a função notória do poder estatal ${ }^{55}$, que

\footnotetext{
${ }^{52}$ Conforme Peter DICKEN (1998, pg. 146), "Uma tecnologia é um processo social embutido socialmente e de forma institucional. É criada e adotada (ou não) pelos agentes humanos: indivíduos, organizações, sociedades. Os modos pelos quais as tecnologias são usadas - inclusive no próprio processo de criação - são condicionados pelo contexto social e econômico".

53 "As escolhas e os usos de tecnologias, portanto, são influenciadas pela busca pelo lucro, pela acumulação do capital e do investimento, pelo aumento da fatia de mercado e assim por diante" (Peter DICKEN, 1998, pg. 146).

${ }^{54}$ É a reunião de "um pensamento coletivo e uma força social capazes de fazer e de manter" (Camille VALLAUX, 1914, pg. 269) uma infra-estrutura.

${ }^{55}$ Compartilhamos da opinião de Camille VALLAUX (1914, pg 269), em que "Uma cadeia de trocas, ao analisá-la em si mesma, não representa outra coisa senão uma totalidade de interesses individuais relativamente numerosos; esses interesses, por totalizados que thes possam supor, não
} 
exercita sua legitimidade nessas ocasiões. Considerando a inconstância histórica dos contextos políticos, além de sociais e econômicos em geral, as inovações se difundem de forma diferenciada e seletiva pelo território.

Não é, portanto, difícil verificar o convívio de gerações tecnológicas em um mesmo contexto. Coexistem, assim, circuitos técnicos mais avançados e menos avançados, castas tecnológicas e, por conseguinte, produtivas. Junto disso, são criadas condições para exercer trocas entre pessoas, famílias, comunidades ou tribos, aldeias, cidades, povos e países, por conta dos excedentes de produção. Era necessário criar condições para fazer circular as pessoas e as mercadorias, de modo a dinamizar a transferência de produtos e a chegada rápida da contrapartida de uma operação de troca, tendo em vista a sobrevivência (e, futuramente, o lucro) dos envolvidos ${ }^{56}$.

As técnicas de produzir e circular persistem pela história adentro, pois nem todos os consumidores podem arcar com os custos ou outros quesitos do produtoparadigma (produzido pelas técnicas mais modernas) do período histórico, permitindo a sobrevivência de diversas gerações técnicas num mesmo período. Surgem os circuitos de concorrência, em que o vencedor seria aquele que fizesse a operação mais competente em todos os sentidos, principalmente no tempo de entrega e na qualidade do produto entregue, conforme a lógica do circuito em que fizesse parte. Compete-se dentro de um circuito e entre circuitos técnicos.

Pela lógica comercial, quanto mais numerosa as operações de troca, maior a contrapartida, e, quanto mais rápida cada operação, maior a probabilidade do produto chegar ileso ou pelo menos em bom estado ao seu destinatário, além de permitir superar os concorrentes. Começou, assim, uma escalada na velocidade de execução das operações, uma aceleração. Tal complexidade e escalada provocou, também, uma aceleração no surgimento das inovações e na condução de produtos, informações e pessoas.

se concentram jamais o bastante para edificar uma obra tão considerável como uma estrada..." (Camille VALLAUX, 1914, pg. 269).

${ }^{56}$ Além de ser o lugar próprio da produção, o espaço sempre é assumido "como âmbito e possibilidade de deslocamento do excedente..." (conforme Joan Eugeni SANCHEZ, 1991, pg. 114). 
Desde cedo a espécie humana precisava circular, primeiro com os próprios pés, depois com os quadrúpedes, daí com apetrechos acoplados aos animais e, então, com as máquinas automotoras. A caça e a coleta exigiam o ato de circular por grandes distâncias, o advento da agricultura, que diminuiu de forma drástica a ação nômade pelo Mundo, não evitou o desenvolvimento dos modos de circular, e, inclusive, o exacerbou. Outro componente essencial que sempre exigiu a habilidade de circular é a escassez. Da escassez e do excedente nasceu a troca, bem como a guerra. Especificamente, com o conseqüente surgimento da troca, demonstrou-se que não se bastaria circular, mas fazê-lo de forma rápida, com o mínimo dos prejuízos, o máximo de retorno e, se possível, com o suplante dos concorrentes. A diferença, desde os tempos primitivos, na propriedade de recursos essenciais, competência produtiva e de circulação das famílias, das tribos e de seus excedentes, resultou na invenção da guerra como recurso da concorrência ou de usurpação dela ${ }^{57}$.

O relógio é um instrumento fundamental para se compreender a sociedade moderna. Graças à subordinação do homem às unidades de subdivisão do tempo, pode-se sincronizar, com grande eficiência, as atividades humanas em diferentes partes do globo, criando, assim, um nexo. Nesse sentido, o tempo transforma-se em norma. A circulação se torna bastante eficaz quando se sincronizam atividades que despertam fluxos com aquelas que os demandam. Sem o relógio, a Globalização seria inviável.

O controle instrumental do tempo, ou a sua sistematização em horas, minutos, segundos e até frações menores, permitiu que se mensurasse o trabalho humano, objetivando a sua eficiência e sua constância, isto é, a sua produtividade. A produtividade está normatizada pelo tempo. Nessa esteira da eficiência é que o aparelho computador foi concebido.

A crescente importância da informação no decorrer dos anos subseqüentes à Segunda Guerra Mundial (1939-1945), tornou imprescindível a inclusão dessa

\footnotetext{
${ }^{57}$ A guerra está, portanto, no âmago dessa discussão, visto que "a guerra não teria sentido se não existisse um espaço a disputar; não se produziriam guerras se não houvesse vontade e possibilidade de apropriação do espaço" (Joan Eugeni SANCHEZ, 1991, pg. 152), bem como uma motivação para tal empreitada.
} 
variável no computador. Com intuito de dar maior produtividade, o computador passaria a ser também um equipamento de comunicação.

Nos anos 60 do século XX, em plena Guerra Fria, os estadunidenses criaram a Internet, como meio de sobrepujar a destruição dos meios convencionais de comunicação no caso de um ataque nuclear maciço da União Soviética. Lembremo-nos de Camille VALLAUX (1914, pg. 272), que, ao dissertar sobre a circulação terrestre, alega possuir sempre um caráter político e de exercício do poder ao fundo, ainda que a justificativa possa ser somente econômica ${ }^{58}$. Isto significa que o Estado cria condições físicas para o exercício do seu poder sobre o território, ainda que conceda a exploração econômica dessas condições. A Internet foi uma criação inicialmente para o uso militar, somente quinze anos depois se passaria a explorá-la economicamente.

Contudo, ainda que se soubesse do potencial desse meio para a circulação das informações, jamais se estimaria o caráter que esse meio de circulação assumiria na virada do século XX para o XXI. A circulação de informação chega ao exacerbo, com pouco controle de qualidade ou mesmo de pudor, ao menos aparentemente. As palavras de Camille VALLAUX (1914) ganham atualidade, ao considerarmos que nessa modalidade de circulação "flui a energia ativa das diferentes formas sociais, e, em particular, dos Estados" (Camille VALLAUX, 1914, pg. 267), o que, portanto, revela intencionalidade. Hoje, é possível consumir, ensinar, medicar e até mesmo roubar e matar, sem estar pessoalmente num outro lugar. Podem-se insultar minorias ou maiorias de sociedades diversas; pode-se, também, assaltar instituições financeiras, ou ainda extravasar perversidades e, como se não fosse o suficiente, combater instituições políticas nacionais e multinacionais, com relativa garantia de escape. Digamos que a Internet radicalizou a percepção de Camille VALLAUX (1914, pg. 267), sobre a liberdade do pensar e da troca de pensamentos ${ }^{59}$. Nesse sentido, é notório que se chegou

\footnotetext{
${ }^{58}$ O motivo mais forte disso é "uma das manifestações exteriores da atividade do Estado, que é quando se propõe transmitir o pensamento e a vontade coletivos sobre todos os pontos de um território" (Camille VALLAUX, 1914, pg. 272)

${ }^{59}$ Esta "sempre tolera as pressões, ou tentativas de pressionar, de uma ou várias vontades sobre outras vontades, aos quais intencionam guiar, contrariar, estimular, sufocar..." (Camille VALLAUX, 1914, pg. 267).
} 
ao abuso de um meio que efetivamente permite o que Camille VALLAUX (1914) chamou outrora de circulação interespiritual, isto é, um meio apropriado para a troca de pensamentos.

Deter informação e os meios de sua difusão, hoje, pode ser mais crucial do que em qualquer outro período da história. Agir e influenciar poderá depender do aperto de uns poucos botões de um painel eletrônico. Estar literalmente presente poderá significar menos presença física e mais a potencialidade e a possibilidade de agir através de meios virtuais (a psicosfera), que são, a cada dia, mais eficazes e eficientes.

A constante introdução de novidades na circulação cria falsas concepções de que o espaço é algo que será, inevitavelmente, suprimido. Confunde-se o aumento da fluidez com a supressão das distâncias físicas. Mas é recorrente a confusão entre as distâncias físicas com espaço. A eficiência e a eficácia das modalidades de circulação superam grandes parcelas dos empecilhos impostos pelo meio físico, mas parecem não ter o mesmo desempenho com relação às culturas. Isso se deve ao fato de haver confusão também na diferenciação entre o espaço e o meio físico. Se as modalidades de circulação, ou qualquer outro conjunto técnico, não encontrassem dificuldades em sua difusão pelas culturas, estaríamos admitindo que o novo sempre substitua o preexistente por completo, algo que, aparentemente, não acontece. Surgiria, então, um arcabouço completamente novo e sem vestígios das práticas anteriores. A competição pode nos esclarecer algo mais: para diferenciar o privilegiado do desprovido são necessárias castas de circulação, que podemos compreender como sendo níveis de competição, em que a velocidade da informação é diretamente proporcional à sua importância na sobrevida do conjunto técnico em voga ${ }^{60}$.

A competição não apenas serve para um consumidor ou usuário. Em verdade, é a força motora dos empreendimentos diversos. Ademais, ainda que a competição discrimine os atores hegemônicos daqueles que estão abaixo, cria-se uma

\footnotetext{
60 "Em um ambiente altamente competitivo, uma vez que uma tecnologia específica esteja em uso por uma firma, então a sua adoção por parte de outros pode tornar-se virtualmente essencial para assegurar uma sobrevivência competitiva" (Peter DICKEN, 1998, pg. 146).
} 
cômoda hierarquia que sustenta algumas vantagens econômicas, políticas e culturais às duas partes, favorecendo a manutenção dessas posições até que ocorra uma ruptura. Podemos exemplificar com a simbiose entre os circuitos superior e o superior marginal, conforme explanado no livro "O Espaço Dividido", de Milton SANTOS (2004). 


\section{9 - A Rede e os Estados-Nações}

Este período contemporâneo nos revela que a Internet não vem modificando os lugares à revelia do que há de preexistente. Ainda que a pretensão seja a de homogeneizar os lugares em termos de informação, a vida nos lugares cria resistências próprias, criando, a partir desse confronto, sínteses locais.

Voltemos ao exemplo que utilizamos no item oito do capítulo 2, em "A Planetarização da Conectividade", com os "Estados-objetos". Os Estados-objetos regulam as ações que por elas incidem, ainda que uma parcela dessas ações possua força suficiente para gerar ascensões ou crises de hegemonias. Há, portanto, uma regulação mutua.

Cada país possui seu respectivo conjunto de paradigmas e preceitos históricos. Dessa maneira, cada entidade nacional enfrentará aquilo que é novo dentro de suas próprias possibilidades, aceitando, rejeitando, adequando ou sendo infiltrado. Desse modo, a Internet não foi aceita em todos os países da mesma forma como o foi nos Estados Unidos. Cada país, na medida em que absorvia a nova tecnologia, criou mecanismos de restrição legal para seus usuários, embora a Internet seja ainda difícil de regular em termos de conteúdo. As restrições que valem para alguns países inexistem em outros.

Vejamos que pela rápida expansão da rede não houve exatamente uma restrição à implantação da infra-estrutura, mas a resistência advém com relação ao conteúdo que pode veiculado através da rede. Trocando pelos nossos conceitos chave, a conectividade é bem-vinda, porém, a virtualidade deve ser controlada dentro de determinados critérios nacionais. Contudo, a Internet de hoje é constituída por diversas entidades, principalmente por empresas privadas, muitas delas localizadas em países com princípios diferentes dos demais. Os conteúdos que violam as leis dos países sede desses sítios são relativamente fáceis de controlar, contudo, a situação se complica quando se tratam de conteúdos hospedados em sítios de outros países, e que causam indignação em um determinado país ou conjunto de países. 
Um caso emblemático das desavenças entre conteúdos situados no estrangeiro e que violam princípios aceitos em outros é o do conflito legal entre a Liga Contra o Racismo e Anti-Semitismo da França e a empresa estadunidense Yahoo! (no ano de 2004) ${ }^{61}$, que hospedava um sítio com conteúdo que fazia apologia ao nazismo e vendia artigos relacionados a este assunto. Nos Estados Unidos, há a primeira emenda da constituição, que garante uma ampla liberdade de expressão, enquanto na França há um banimento geral de qualquer forma expressão relativa ao nazismo, devido à traumática experiência da Segunda Guerra Mundial. O sítio estava hospedado nos Estados Unidos, enquanto a violação foi na França. Essa polêmica foi terminada com uma série de restrições providenciadas pelo Yahoo! na França, impedindo que aquele sítio transgressor fosse acessado a partir do território francês. A Internet, assim, desencadeou uma série de discussões no âmbito das Relações Internacionais.

Uma edição do Financial Times, de 08/07/1999 (Reino Unido) trazia a seguinte manchete: "Estados árabes falham em curvar a Internet". A frase é atribuída a um relatório da ONG Human Rights Watch, de direitos humanos, feito na época. De acordo com esse artigo do Financial Times, os Estados autocráticos do norte da África e do Oriente Médio estavam tendo dificuldades com o acesso quase indiscriminado ao conteúdo da Internet.

${ }^{61}$ A referência usada foi uma reportagem da revista "Managing Intellectual Property" (Londres, novembro de 2004. pg. 1) 


\section{0 - A Rede e os Grupos}

Assim como a globalização distribuiu riqueza, também o fez com a pobreza. Da mesma forma, distribuiu a tecnologia de informação para a comodidade e conveniência dos atores hegemônicos onde quer que estejam, e também o fez para o proveito dos desvalidos, injustiçados, indignados e combatentes. Os governantes dos países estão cada vez mais cientes disso, e também buscam criar mecanismos legais para tentar deter grupos que, potencialmente, possam desestabilizar o status quo. Os países autoritários ou autocratas estão entre aqueles que mais buscam controlar o acesso da população à Internet, por conseguinte, permitindo monitorar tais organizações.

Este período se caracterizou pelo uso bastante intenso da Internet por parte de muitos grupos reivindicatórios, como os Zapatistas (México), o PKK (Partido dos Trabalhadores Curdos), o Greenpeace e até o MST (Movimento dos Trabalhadores Rurais Sem-Terra), do Brasil. Há também um uso intenso da Internet por parte dos grupos combatentes no Oriente Médio, como o da resistência armada à ocupação anglo-americana no Iraque (desde março de 2003) e os partidários da causa palestina contra o Estado de Israel. A mesma Internet que permite a manutenção e a intensificação das intenções dos atores hegemônicos da economia e da política também favorece a divulgação das causas que os opõem. Não é raro o uso da Internet, inclusive, para a incitação e planejamento de ações contra oponentes políticos e militares.

Há também os grupos temporários, por convergência de opinião, que se formam por ocasião de algum evento político ou econômico de escala mundial ou nacional. Um exemplo disso foi o ataque maciço ao sítio da OTAN por parte de hackers na ocasião do bombardeio da Sérvia, em 1999, por conta do conflito do Kossovo ${ }^{62}$. Outro caso é o recorrente confronto dos hackers da China com os de Taiwan ${ }^{63}$,

\footnotetext{
${ }^{62}$ http://news.bbc.co.uk/1/hi/sci/tech/308788.stm e http://www.contentwire.com/cans/cans.cfm?ccs $=106 \& \mathrm{cs}=900$.

${ }^{63}$ http://chinadigitaltimes.net/2004/11/china_hackers_m.php e http://news.zdnet.com/21009595_22-515403.html
} 
como se fosse um extravasamento da tensão existente relativo ao impasse da soberania chinesa desde 1949. 


\section{1 - Da Inclusão Digital}

Em geral, fala-se em inclusão digital como um fator que pode tirar famílias da marginalidade. De fato, se houver outras políticas paralelas mais importantes, como o acesso à água encanada, à saúde e ao saneamento, à alimentação e à moradia, a inclusão digital pode transformar uma pessoa desprivilegiada em um indivíduo mais ativo e influente dentro da sociedade, desde que esteja amplamente apoiada em políticas educacionais. Em nosso questionário, 84\% (21 pessoas) dos entrevistados consideram que a Internet é "um meio complementar aos instrumentos educacionais, e, com a devida orientação de pessoas esclarecidas, poderá se tornar uma forte ferramenta para a inclusão social". Portanto, pode-se até pensar em utilizar a tecnologia de informação como instrumento para auxiliar na inclusão social, porém, não basta a inclusão digital para se considerar que houve propriamente a inclusão social.

A inclusão digital, por si, é uma necessidade sistêmica e histórica, não é uma necessidade fisiológica do indivíduo. É uma demanda dos atores hegemônicos, em busca de seus objetivos, à revelia das necessidades básicas de sobrevivência do indivíduo. Contudo, a inclusão digital é uma necessidade social fundamental ao indivíduo, devido à conjuntura atual das relações sociais. O período histórico em que vivemos, portanto, exige a inclusão digital dos indivíduos. Hoje, as oportunidades de emprego, os movimentos bancários, os impostos, as notícias, as decisões políticas e muitas outras coisas estão ao alcance através da Internet (a virtualidade), e quem mais aproveita desse instrumento, mais "incluído" está.

Feitas estas considerações, gostaríamos de elucidar que a inclusão digital exige uma expansão da conectividade e a criação de um senso crítico que permita aos indivíduos embrenharem pela virtualidade. O primeiro trata de melhorias consideráveis de infra-estrutura, enquanto o outro se refere ao acesso a uma educação que tenha os instrumentos e incentivos necessários para preparar os indivíduos para o mundo virtual. Há uma expressão territorial para a inclusão digital: aumento de objetos técnicos e de organizações condutoras da inclusão (como ONGs e escolas técnicas). 
Alguns estudos a respeito da inclusão digital no Brasil na Geografia vêm sendo conduzidos principalmente pelos geógrafos Hindenburgo Francisco Pires (UERJ) e Michele Tancman Candido da Silva (UCAM/UNIVERSO/CECIERJ). Ambos partem do conceito de "Ciberespaço" para elucidar a problemática. O conceito de Ciberespaço é a conjunção da conectividade com a virtualidade, isto é, trata-se do que Hindenburgo PIRES (2004) chama de "uma geografia de redes e nós e a formação de um espaço de fluxos". 
CONCLUSÕES: A UNICIDADE TÉCNICA, SOB A ÉGIDE DA INTERNET E OS IMPACTOS NA ORGANIZAÇÃO E ORDENAÇÃO TERRITORIAL 


\section{1 - Conectividade Planetária, Virtualidade Mundial}

$\mathrm{O}$ ato de conectar-se é o mesmo que estabelecer uma interação entre pessoas através de um mecanismo de codificação e decodificação de pulsos, utilizando-se um mecanismo eletrônico de interlocução. A conectividade é a conseqüência direta da eficácia e da eficiência de um ou mais meios que permitam uma determinada interação. Um aparelho de fax, um telefone e um MODEM (sigla da língua inglesa para "modulator and demodulator", literalmente, codificador e decodificador) estabelecem a conectividade de seu proprietário com outros que possuam esses mesmos aparelhos. Não entremos agora no mérito das tecnologias de fusão de funcionalidade (os aparelhos multifuncionais etc.). O que convém explanar é que as distâncias física e linear (considerados no senso comum) tendem a se anular entre os possíveis interlocutores. Pode-se enviar um fax para a padaria da esquina como para um morador da Sibéria, desde que também possuam um aparelho de fax para receber a mensagem, e, praticamente, com a mesma duração na transmissão. A distância se anula, mas o meio físico e as sociedades são latentes, pois se o deslocamento das pessoas se faz desnecessário, é porque existe um cabo ou outro meio de propagação de pulso que compensa tal ação. Também, como já mencionamos há pouco, a conectividade está subordinada à quantidade de aparelhos, conectores e cabos disponíveis e à distribuição planetária disso tudo. Essencialmente, conectividade diz respeito ao estado de possibilidades de conexão.

A conectividade é um artifício que objetiva burlar o meio físico, enquanto a virtualidade visa anular quaisquer atritos com as sociedades. As técnicas devem superar os obstáculos do meio físico e equilibrar-se com os preceitos sociais locais ${ }^{64}$, e assim difundir-se pelo mundo. Do contrário, se há grandes falhas na superação desses obstáculos, a invenção jamais sairá de sua condição experimental.

\footnotetext{
${ }^{64}$ Temos como preceitos sociais os valores intrínsecos a cada uma das inúmeras sociedades no Mundo, dentre os quais a percepção política, econômica e cultural dos países, das províncias, dos municípios e das residências.
} 
Efetivamente, a conectividade é desigual e concentrada. É desigual por se distribuir de forma prioritária conforme a demanda dos capitais, o que a faz também concentrar-se no território. A virtualidade é, potencialmente, igual para todo o mundo. Contudo, ela é regulada por mecanismos legais em diversos países, o que a perfaz diferente a cada lugar. A conectividade possui um discurso universalista e determinista, mas não é aceita de forma unânime. Tampouco sua relevância pode ser considerada unânime, pois depende de que parcela da sociedade estamos falando. O discurso universalista serve para dar legitimidade, alegando-se uma função social e democrática, e negando sua natureza desigual e concentrada. O viés determinista do discurso traz consigo uma alegação de inevitabilidade histórica, despertando a crença de que a conectividade é uma necessidade humana, fruto de uma evolução genética. Há uma tendência a se proclamar que o Mundo caminhará inevitavelmente rumo ao contexto da conectividade universal, porém, acreditamos que isso está distante de ser uma verdade. Ademais, será que todos os seres humanos a querem? Sob um regime de inúmeras variedades de sociedades, indivíduos, culturas e contextos econômicos locais, a conectividade certamente persistirá indefinidamente. Por outro lado, é ingenuidade ou raciocínio simplista acreditar que a virtualidade será aceita de forma unânime e calorosa, enquanto meio de vida, em todas as sociedades ou por todos os indivíduos de uma sociedade qualquer. Na difusão dos mecanismos da conectividade, há desde aqueles que "preferem morrer" a que ficar sem a virtualidade, passando por aqueles que se opõem ou fazem uso crítico, ou então pelos que sabem que logo ficarão de fora (em função da velocidade e custo de implantação das inovações), até aqueles que se posicionam de forma inerte ou passiva em relação às inovações. Independentemente disso, há uma coerção que atinge a todos, seja qual for a opção.

Digamos que a conectividade fosse capaz de sobrepujar sempre os valores locais. Isso faria com que chegássemos à conclusão ridícula e grotesca de que os aviões de ajuda humanitária da ONU deveriam distribuir sacos de arroz acompanhados de aparelhos de fax àqueles exauridos pela fome ou pela guerra. É utopia pensar em conectividade universal se as questões de disparidade econômica não forem 
amenizadas ou até mesmo resolvidas pelas sociedades, bem como acreditar que isso é algo que será resolvido em curto prazo, ainda que sob a bandeira da conectividade. Sem a oportunidade, não há como pensar em universalidade, seja lá qual for a conotação. A liberdade está no âmago da universalidade, e, enquanto a primeira for negada aos desfavorecidos, a segunda permanecerá no plano das utopias por tempo indeterminado. Não basta ter um computador ligado à Internet $\mathrm{e}$ um aparelho de projeção de multimídia numa escola pública se boa parte dos jovens estudantes não têm o que comer em casa por conta do desemprego dos pais. A conectividade permanece, portanto, desigual e concentrada, permitindo maior "liberdade" aos que acreditam estar livres, e criando um precipício ainda maior aos desfavorecidos.

No mundo envolvido pela conectividade, existem duas formas de inserção dos indivíduos, coerentes com a estratificação das sociedades: o usuário direto e o usuário submisso. O usuário direto é aquele que possui um computador em sua residência, e utiliza a computação de forma instrumental para as suas atividades profissionais. Esse tipo de usuário não é necessariamente um programador, mas desfruta da computação de modo a atender demandas simples ou complexas de seu cotidiano. Possui um mínimo grau de autonomia ao operar um computador. Grosso modo, os usuários diretos geralmente se concentram nas classes média e alta. O usuário submisso é aquele que utiliza computadores, mas somente na administração de seu dinheiro e em seus deveres e direitos civis através de terminais públicos. Porém, o uso do computador no trabalho é condicionado a ações predeterminadas. Quando um usuário submisso utiliza o computador no trabalho, este é adestrado em comandos bastante específicos, a exemplo dos operadores de caixas de supermercados. Há que se considerar também o eventual contato através do lazer (jogos eletrônicos) ou da educação (programas escolares). Os usuários submissos concentram-se entre as classes menos abastadas, bem como entre as pessoas de todas as classes nascidas antes da década de 1960. Curiosamente, a criatividade, fator inerente das classes sociais menos favorecidas, é simplesmente anulada com o adestramento. 
Ambos os tipos de usuário (direto ou submisso) encontram-se submetidos às determinações institucionais (públicas e privadas), permanecem cadastrados em bancos de dados sem expressa autorização, e são dependentes de funções exercidas por uma burocracia informatizada.

A conectividade, para todos os efeitos, não é páreo para sobrepujar as sociedades, ainda que tenha capacidade de burlar o meio físico. A Internet tem seu alcance forçosamente conforme os padrões das diversas sociedades humanas, e expande-se ou encontra soluções de continuidade conforme os ritmos e conceitos humanos preexistentes. Só se quebram barreiras de quem as deixa quebrar, através de instrumentos políticos e legais, legitimados por parcelas hegemônicas da sociedade. A toda novidade que é posta à mesa, os seres humanos variam de reação sob um espectro que vai dos deslumbrados aos mais desconfiados, tudo em função dos conceitos e paradigmas que foram engendrados no período histórico preexistente à novidade que lhes é apresentada. Há que se relevar o fato de que a Internet é um mecanismo de conectividade múltipla. Isso porque envolve propriedades diversas (som, imagem, possibilidade de simulação etc.), o que eleva a condição da conectividade à de virtualidade. Neste sentido, resta-nos propor que a Internet engendra uma dimensão altamente fluida da realidade, e, por essa razão, acrescenta maior espessura de fluxos ao espaço. 


\section{2 - O Espaço Vertiginoso}

A mídia de massa, de acordo com Abraham MOLES (1973), redefine as classes sociais, entre as que engendram seus propósitos através dos meios de comunicação, e aqueles que são susceptíveis aos seus preceitos através desses meios. Podemos distinguir, assim, os atores hegemônicos dos demais atores da sociedade. Podemos, ainda, falar na visão desses atores hegemônicos sobre qual o objetivo da inclusão digital. A liberdade digital se definirá conforme graus de "ofelimidade", isto é, o equilíbrio entre os desejos pessoais e as imposições da sociedade. Quanto maior a ofelimidade, maior a prevalência dos desejos pessoais sobre as imposições da sociedade. Dessa forma, maior será o domínio sobre as próprias ações na virtualidade. Um funcionário dedicado das bolsas de valor em São Paulo dispõe de menor ofelimidade que um ativista político que escreve livremente as suas idéias em um blog e provoca seus interlocutores.

O estabelecimento da virtualidade permitiu ações a distância. Enquanto isso, o sempre acelerar dos meios de circulação, as castas dessa modalidade por conta da permanência de técnicas ultrapassadas se fazem presentes. É interessante observar que ação, circulação, circuitos e simulação são modalidades do espaço, tal como a Geografia o estuda amplamente, mas também são modalidades do virtual. Pode-se pensar, assim, em uma razão temporal vertiginosa, una e mundial. Contudo, a vertigem impressa pelos vetores mundializantes não infiltram pelas civilizações humanas de forma impositiva e ilesa, como se nos seus alvos nada houvesse. Existem níveis de atrito nas localidades, tão diversos quanto for 0 número de lugares, que variam desde a relativa passividade até a resistência mais feroz. Não subestimemos, portanto, o poder das horizontalidades, ainda que devamos estar cientes da implacabilidade das verticalidades (com base em Milton SANTOS, 1996).

A possibilidade de se pensar em espaço virtual, retirando-se os preconceitos, permite que se pense em uma virtualidade do território, que, por conseguinte, leva-nos direto às modalidades de administração do território. O tempo se torna padrão, mundial e uno, mas nunca sucumbirá, pois o tempo é o do agente 
humano e da sua necessidade de agir. Não nos olvidamos de que virtualidade é, antes de tudo, algo que inspira apenas tendência, não é unânime e sequer absoluto, graças às horizontalidades. Qualquer ação, por mais rápida que possa ser, jamais poderá ser feita fora da razão espaço-temporal, e apenas imprimirá uma vertigem. Sempre haverão os "homens lentos", como diria o saudoso professor Milton Santos, para apenas franzir as sobrancelhas diante do novo. 


\section{REFERÊNCIAS BIBLIOGRÁFICAS}


BACHELARD, Gaston. A Dialética da Duração. (La dialectique de la durée) Trad. Marcelo Coelho. Editora Ática, São Paulo, 1994. $2^{\text {a }}$ ed. c.1950 (Presses Universitaires de France)

BAUDILLARD, Jean. À Sombra das Maiorias Silenciosas: O fim do social e o surgimento das massas. Ed. Brasiliense, São Paulo, 1985, $1^{\text {a }}$ ed.

BAUMAN, Zygmunt. Globalização: As Conseqüências Humanas. Trad. Marcos Penchel. Jorge Zahar Editor, Rio de Janeiro, 1999.

CASTELLS, Manuel. A Sociedade em Rede. Vol. 1: A Era da Informação Economia, Sociedade e Cultura. Trad. Roneide Majer. Ed. Paz e Terra, São Paulo, 1999, 3ª ed.

DIAS DE SOUSA, Ivo. Negócios e Internet. FCA - Editora de Informática Ltda., Lisboa, 1997.

DICKEN, Peter. Global Shift: Transforming the World Economy. London: Paul Chapman Publishing Ltd., 1998.

DUPAS, Gilberto. Ética e Poder na Sociedade da Informação. Editora UNESP, São Paulo, 2000.

KUHN, Thomas S. A Estrutura das Revoluções Científicas. Trad. Beatriz e Nelson Boeira. Ed. Perspectiva, São Paulo, 2001, $6^{\text {a }}$ ed.

GATES, Bill. A Estrada do Futuro. Trad. Beth Vieira. Ed. Companhia das Letras, São Paulo, 1995.

GAUDIN, Thierry. Economia Cognitiva: Uma introdução. Trad. Paulo Anthero S. Barbosa. Editora Beca Produções Culturais Ltda., São Paulo, 1999.

HABERMAS, Jürgen. Técnica e Ciência como "Ideologia". Trad. Artur Morão. Edições 70, Lisboa, 2001.

HOBSBAWM, Eric. Era dos Extremos: O breve século XX: 1914-1991. Trad. Marcos Santarrita. Ed. Companhia das Letras, São Paulo, 1995. 
LÉVY, Pierre. As Tecnologias da Inteligência: O futuro do pensamento na era da informática. Trad. Carlos Irineu da Costa. Ed. 34, São Paulo, 1993, $1^{a}$ ed., $13^{\mathrm{a}}$ reimpressão.

LÉVY, Pierre. Cibercultura. Trad. Carlos Irineu da Costa. Ed. 34, São Paulo, $2000,2^{\mathrm{a}}$ ed.

LÉVY, Pierre. A Conexão Planetária: O mercado, o ciberespaço, a consciência. Trad. Maria L Homem \& Ronaldo Entler. Ed. 34, São Paulo, 2001, $1^{\text {a }}$ ed.

MANDEL, Arnaldo et alli. "Informação: Computação e Comunicação". In: Revista USP, 35 (4), Dossiê Informática/Internet. p. 10-45, Coordenadoria de Comunicação Social da Universidade de São Paulo, São Paulo, Setembro/Outubro/Novembro de 1997.

MATTOS, Carlos de Meira. Geopolítica e Trópicos. Rio de Janeiro: Biblioteca do Exército, 1984.

MOLES, Abraham. Rumos de uma Civilização Tecnológica. Trad. Pérola de Carvalho. Ed. Perspectiva, São Paulo, 1973.

PIRES, Hindenburgo Francsco. Estruturas virtuais de acumulação e cibercidades. Scripta Nova - Revista Eletrônica de Geografia y Ciências Sociales, Universidad de Barcelona, Vol. VIII, no 170 (59), 01/08/2004.

SANCHEZ, Joan Eugeni. Espacio, economia y sociedad, Madrid: Siglo Veintiuno, 1991

SANTOS, Milton. A Natureza do Espaço: Técnica e tempo, razão e emoção. Ed. HUCITEC, São Paulo, 1996.

SANTOS, Milton. Metamorfoses do Espaço Habitado: Fundamentos teóricos e metodológicos da Geografia. Ed. HUCITEC, São Paulo, 1988.

SANTOS, Milton. O Espaço Dividido: Os dois circuitos da economia urbana 
nos países subdesenvolvidos. Ed. Francisco Alves, Rio de Janeiro, 1979.

SANTOS, Milton. Por Uma Economia Política da Cidade: O caso de São Paulo. Ed. HUCITEC, São Paulo, 1994a.

SANTOS, Milton. Técnica, Espaço e Tempo: Globalização e meio técnicocientífico-informacional. Ed. HUCITEC, São Paulo, 1994b.

SANTOS, Milton (e) SILVEIRA, María Laura. O Brasil: Territrório e sociedade no início do século XXI. Editora Record, Rio de Janeiro, 2001, $2^{\mathrm{a}}$ ed.

SARTRE, Jean-Paul. Being and Northingness: A phenomenological essay on ontology. Tradução inglesa de Hazel E. Barnes. Washington Square Press, Nova York, 1992.

SCHAFF, Adam. A Sociedade Informática: As conseqüências sociais da segunda revolução industrial. Trad. Carlos Machado \& Luiz Obojes. Ed. Brasiliense, São Paulo, 1990, 1ª ed., $8^{a}$ reimpressão.

VALLAUX, Camille. El Suelo y el Estado, Madrid: Daniel Jorro Editor, 1914.

WHITEHEAD, Alfred North. A Função da Razão. (The Function of Reason) Trad. Fernando Dídimo Vieira. Coleção Pensamento Científico. Ed. UnB, Brasília, 1988, 2a ed. c.1929 (Princeton University Press)

ZAKON, Robert Hobbes. Hobbes Internet Timeline, versão 7.0. Adquirido em 8 de agosto de 2004 do endereço:

\section{http://www.zakon.org/robert/Internet/timelinel}




\section{ANEXO - QUESTIONÁRIO SOBRE MEIOS E MODALIDADES DE COMUNICAÇÃO}




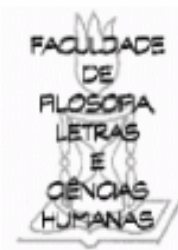

UNIVERSIDADE DE SÃO PAULO

FACULDADE DE FILOSOFIA, LETRAS E CIÊNCIAS HUMANAS

PROGRAMA DE PÓS-GRADUAÇÃO EM GEOGRAFIA HUMANA

\section{MEIOS E MODALIDADES DE COMUNICAÇÃO ALEXANDER SERGIO EVASO}

Por modalidades de comunicação definimos os aparatos ou conjuntos de aparatos que constituem interfaces entre as partes para a comunicação escrita ou falada, sem conotação informativa, necessariamente. O fax, o telefone, o aparelho de telex, o rádio e a carta postal são modalidades de comunicação. A Internet é um meio que abriga diversas modalidades de comunicação (e-mail, programas de escrita em tempo real - ICQ e MSN entre outros - e programas de comunicação falada em tempo real - Skype e PalTalk, entre outros).

Deixemos de lado a definição conhecida dos “meios de comunicação” (conjunto dos jornais, revistas, canais de televisão e estações de rádio), e entendamos que isso resume comunicação ao jornalismo, exclusivamente.

Consideremos como meios de comunicação o conjunto de tecnologias associadas à difusão da comunicação, inclusive os aparelhos diretamente envolvidos no envio e na recepção. Um meio de comunicação pode ser a telefonia, mas as modalidades podem ser o fax e o aparelho telefônico.

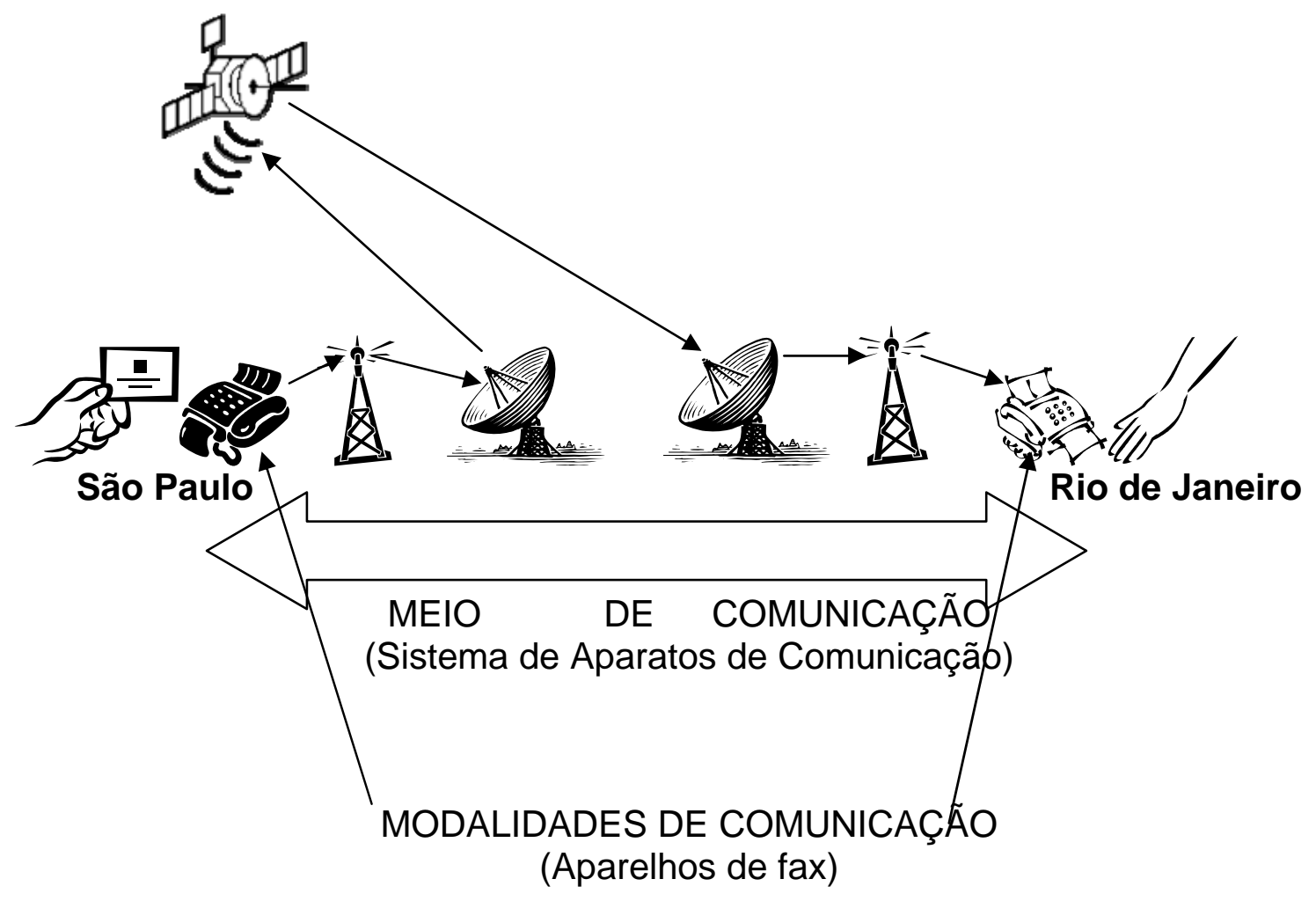




\section{UNIVERSIDADE DE SÃO PAULO}

\section{FACULDADE DE FILOSOFIA, LETRAS E CIÊNCIAS HUMANAS}

\section{PROGRAMA DE PÓS-GRADUAÇÃO EM GEOGRAFIA HUMANA}

Tendo em vista a Internet como meio, e as suas modalidades como foco de nossa pesquisa, lhe fazemos as seguintes questões:

1) Assinale abaixo todas as modalidades de comunicação que você já utilizou na Internet:

( ) Correio Eletrônico (e-mail)

( ) Mensageiros instantâneos*, somente usando a comunicação escrita em tempo real

( ) Mensageiros instantâneos*, utilizando, além da escrita, também recursos de áudio e/ou vídeo em tempo real

( ) Nenhum (Pule para a questão 3)

* Exemplos de mensageiros instantâneos: MSN (Messenger), Yahoo! Messenger, IRC, ICQ, AIM, Trillian, Skype, PalTalk, Windows Live Messenger, Google Talk, IM2, Jabber, MySpace IM, Proteus, PSI e Zovine.

2) Assinale abaixo apenas 4 opções (1 = mais importante a 4 = menos importante).

( ) Comunicação de procedimentos de trabalho

( ) Comunicação com familiares distantes

( ) Comunicação com amigos

( ) Comunicação com parceiros de atividade

( ) Acesso a serviços bancários

( ) Pesquisa Acadêmica

( ) Comunicação com clientes

( ) Participação em grupos de discussão

( ) Serviços de saúde
( ) Atividades no Sistema Financeiro

( ) Namoro e/ou amizade

( ) Compras (Comércio Eletrônico)

( ) Vendas (Comércio Eletrônico)

( ) Prestação de consultoria

( ) Atividades de Mala-Direta

( ) Comando de equipes remotas

( ) Transmissão de dados de trabalho

( ) Lazer em geral (mensagens e troca de arquivos)

3) Com a quantidade de modalidades de comunicação existentes ao seu redor (fax, e-mail, telefone etc.), seja em casa, no trabalho ou no ambiente de estudo, assinale a frase que mais se identifica com sua opinião:

( ) Me sinto suficientemente poupado de me deslocar pessoalmente para os lugares, pois utilizo modalidades de comunicação em grande parte de meu cotidiano.

( ) Dependo do deslocamento pessoal para os lugares para exercer algumas atividades, pois não tenho acesso suficiente a modalidades de comunicação.

( ) Dependo do deslocamento pessoal para os lugares para exercer algumas atividades, pois as modalidades de comunicação existentes são insuficientes para resolver meus problemas cotidianos.

( ) Prefiro deslocar-me pessoalmente para os lugares para exercer as minhas atividades, independentemente de eu ter ou não acesso a modalidades de comunicação.

( ) As modalidades de comunicação não influem na minha necessidade de deslocamento para os lugares para exercer minhas atividades. 


\section{UNIVERSIDADE DE SÃO PAULO}

\section{FACULDADE DE FILOSOFIA, LETRAS E CIÊNCIAS HUMANAS}

\section{PROGRAMA DE PÓS-GRADUAÇÃO EM GEOGRAFIA HUMANA}

4) Com relação à Internet, assinale a frase que mais se identifica com a sua opinião:

( ) Não uso a Internet.

( ) Sou capaz de interferir em decisões e procedimentos à distância, pois a Internet permite comunicar-me perfeitamente com pessoas e/ou entidades.

( ) A Internet agiliza minha vida (seja profissional, estudantil ou pessoal), porém, ainda de forma pouco significativa.

( ) A Internet agiliza bastante minha vida (seja profissional, estudantil ou pessoal), porém, não consigo interferir em decisões ou procedimentos à distância.

5) Na relação entre velocidade e Internet, assinale a frase que mais se identifica com sua opinião:

( ) A Internet não interferiu em nada no meu modo de vida, pois não a uso ou não desejo utilizá-la (Pule para a questão 10).

( ) A Internet acelerou minha vida porque faço mais atividades em menos tempo.

( ) A Internet acelerou minha vida de forma pertinente, de modo que posso dar conta das minhas tarefas cotidianas.

( ) A Internet interferiu em minha vida de modo que possuo mais tempo para o lazer.

( ) Mesmo sendo usuário da Internet, eu não sinto diferença no volume de atividades que devo dar conta em um mesmo dia.

6) Com relação ao volume de informações que você recebe diariamente por correio eletrônico, assinale a frase que mais se identifica com a sua opinião:

( ) Eu recebo diariamente uma quantidade de informações que não dou conta de absorver.

( ) Eu consigo, com relativa dificuldade, ainda absorver a quantidade de informações que recebo diariamente.

( ) Eu consigo, sem dificuldade, absorver a quantidade de informações que recebo diariamente.

7) Qual a sua percepção do meio Internet? Assinale abaixo qual a frase mais próxima de sua opinião:

( ) A Internet é um meio livre porém irresponsável, um meio para se manifestar pensamentos anarquistas e perversidades.

( ) A Internet é um meio controlado, creio que todas as nossas ações são monitoradas por agentes do governo dos Estados Unidos e de outros países.

( ) A Internet é um meio livre e responsável, democrático por excelência, pois permite a manifestação das diversas culturas e opiniões existentes no mundo.

( ) A Internet pode ser um meio de divulgação de resistências, pois sua influência permite a amplificação de movimentos sociais localizados pelo mundo afora.

( ) A Internet é um espelho do mundo em que vivemos, portanto, os mesmos perigos e percalços que encontramos na vida também encontramos na Internet.

( ) A Internet é sinônimo de emancipação e de liberdade. Cada um faz o que quiser. 


\section{UNIVERSIDADE DE SÃO PAULO}

\section{FACULDADE DE FILOSOFIA, LETRAS E CIÊNCIAS HUMANAS}

\section{PROGRAMA DE PÓS-GRADUAÇÃO EM GEOGRAFIA HUMANA}

8) Assinale abaixo os dois termos que para você representam mais a Internet, em sua opinião:

( ) Amplitude Cultural.

( ) Abrangência Territorial.

( ) Volume (quantidade de informações).

( ) Densidade (consigo me aprofundar muito nos assuntos e nas informações).

( ) Velocidade (rapidez na obtenção daquilo que é de meu interesse).

9) Em sua opinião, a Internet...

( ) ...é uma moda passageira, que em breve será substituída por outro modismo do Capitalismo.

( ) ...será um meio complementar aos meios de circulação existentes (automóveis, trens etc.), colaborando para melhorar o trânsito das grandes cidades e, conseqüentemente, a poluição do ar, devido à praticidade que ela dá à resolução de problemas pessoais e profissionais.

( ) ...será um meio complementar aos meios de circulação existentes (automóveis, trens etc.), contudo, corre em paralelo aos problemas de trânsito das grandes cidades e de muitas injustiças sociais, ainda que resolva problemas pessoais e profissionais com eficácia.

( ) ...jamais substituirá os automóveis, ônibus e trens, pois não é um meio de circulação, apenas de comunicação.

10) Quanto à inclusão social, a Internet...

( ) ...é um meio que permite inclusão social, pois dá acesso a uma grande quantidade de informações para a população carente.

( ) ...é um meio que colaborará para a exclusão social, pois só quem detém as condições de avaliar as informações é quem conseguirá tirar proveito.

( ) ...é um meio complementar aos instrumentos educacionais, e, com a devida orientação de pessoas esclarecidas, poderá se tornar uma forte ferramenta para a inclusão social.

( )...é uma invenção que conduz à elitização das informações.

11) Assinale abaixo as atividades do comércio eletrônico que você já utilizou:

( ) Nunca comprei nada através da Internet, nem desejo fazê-lo.

( ) Nunca comprei nada através da Internet, mas desejo fazê-lo algum dia.

( ) Grandes varejistas virtuais nacionais (Lojas de variedades)*.

( ) Grandes varejistas virtuais estrangeiros (Lojas de variedades).

( ) Livrarias virtuais nacionais (Saraiva, Cultura, Siciliano etc.).

( ) Livrarias virtuais estrangeiras (Amazon, Barnes \& Noble etc.).

( ) Sítios (sites) de leilão nacionais (Mercado Livre, Lokau etc.).

( ) Sítios (sites) de leilão estrangeiros (e-Bay, De Remate etc.).

( ) Shoppings Virtuais (ou sítios de Comparação de preços)**.

( ) Sítios de Companhias Aéreas e de Turismo.

( ) Sítios exclusivamente dedicados à informática e afins.

( ) Sítios exclusivos dos fabricantes de um produto que você estava à procura.

( ) Sítios exclusivos dos prestadores de algum serviço que você estava à procura.

* Sítios como Submarino, Americanas, Extra, FastShop, Shoptime, Magazine Luiza etc.

** Sítios como o eBit, BondFaro, Mercado na Web, PreçoMania e BuscaPé 


\section{UNIVERSIDADE DE SÃO PAULO FACULDADE DE FILOSOFIA, LETRAS E CIÊNCIAS HUMANAS \\ PROGRAMA DE PÓS-GRADUAÇÃO EM GEOGRAFIA HUMANA}

12) Caso você já tenha utilizado quaisquer das atividades do comércio eletrônico descritos na questão 11, assinale abaixo todas as modalidades de pagamento que tenha utilizado para concretizar algum negócio:

( ) Nunca utilizei o comércio eletrônico pessoalmente.

( ) Cartão de Crédito.

( ) Transferência de Fundos on-line (pagamento em tempo real).

( ) Depósito bancário (indo pessoalmente ao banco, ou no caixa eletrônico da rede).

( ) Boleto Bancário (pagando on-line ou mesmo indo ao banco pessoalmente).

( ) Ordem de pagamento (Western Union, PayPal, Mercado Pago e outros).

( ) Dinheiro, pagando pessoalmente, ainda que tenha fechado negócio via Internet.

13) Você possui qualquer acesso em banda larga* em sua residência?

( ) Não

( ) Sim

( ) Não tenho qualquer acesso à Internet.

* Speedy, Virtua, Velox, Ajato, Net, Giro, Canbras, Turbo, Inter Cabo etc.

14) Em busca de conhecimento, assinale quais as modalidades de sítio de Internet que você já tenha utilizado:

( ) Nunca utilizei a Internet em geral.

( ) Nunca utilizei a Internet com essa finalidade.

( ) Jornais.

( ) Bibliotecas virtuais.

( ) Edições eletrônicas de revistas existentes em bancas.

( ) Revistas exclusivamente de tiragem eletrônica.

( ) Revistas indisponíveis no Brasil em papel.

( ) Bloggers e/ou Grupos de Discussão.

( ) Universidades nacionais.

( ) Universidades estrangeiras.

( ) ONGs (Organizações Não-Governamentais)

( ) Empresas

( ) Órgãos do Estado (Sítios da Administração Pública)

15) Caso você seja um empreendedor ou empresário consolidado, assinale abaixo quais os recursos da Internet que o seu estabelecimento utiliza em seu cotidiano (com finalidade produtiva):

( ) Não sou empresário ou empreendedor (Pule a próxima questão).

( ) Correio eletrônico (e-mail).

( ) Mensageiros Instantâneos (inclusive programas personalizados de atendimento em tempo real).

( ) Sítio (website)

( ) Weblog (ou Blog)

( ) Intranet e Extranet 
Faclionas

DE

ALOSCFA

IETRAS

$82 \mathrm{E}$

HuMANAS
UNIVERSIDADE DE SÃO PAULO

FACULDADE DE FILOSOFIA, LETRAS E CIÊNCIAS HUMANAS

PROGRAMA DE PÓS-GRADUAÇÃO EM GEOGRAFIA HUMANA

16) Você possui qualquer acesso em banda larga em seu estabelecimento?

( ) Não

( ) Sim

( ) Não tenho qualquer acesso à Internet.

* Speedy, Virtua, Velox, Ajato, Net, Giro, Canbras, Turbo, Inter Cabo etc.

Pedimos que fiquem à vontade para incluir ou não quaisquer dos dados abaixo, apenas para fins de arquivamento. As informações pesquisadas neste questionário serão submetidas a estatísticas, e não serão divulgadas fora do âmbito de nosso trabalho.

NOME:

GÊNERO: ( ) Feminino ( ) Masculino

ATIVIDADE/PROFISSÃO 